\title{
Retention of new blood donors : implications for interventions
}

Citation for published version (APA):

van Dongen, A. (2013). Retention of new blood donors : implications for interventions. [Doctoral Thesis, Maastricht University]. Maastricht University. https://doi.org/10.26481/dis.20131209ad

Document status and date:

Published: 01/01/2013

DOI:

10.26481/dis.20131209ad

Document Version:

Publisher's PDF, also known as Version of record

\section{Please check the document version of this publication:}

- A submitted manuscript is the version of the article upon submission and before peer-review. There can be important differences between the submitted version and the official published version of record.

People interested in the research are advised to contact the author for the final version of the publication, or visit the DOI to the publisher's website.

- The final author version and the galley proof are versions of the publication after peer review.

- The final published version features the final layout of the paper including the volume, issue and page numbers.

Link to publication

\footnotetext{
General rights rights.

- You may freely distribute the URL identifying the publication in the public portal. please follow below link for the End User Agreement:

www.umlib.nl/taverne-license

Take down policy

If you believe that this document breaches copyright please contact us at:

repository@maastrichtuniversity.nl

providing details and we will investigate your claim.
}

Copyright and moral rights for the publications made accessible in the public portal are retained by the authors and/or other copyright owners and it is a condition of accessing publications that users recognise and abide by the legal requirements associated with these

- Users may download and print one copy of any publication from the public portal for the purpose of private study or research.

- You may not further distribute the material or use it for any profit-making activity or commercial gain

If the publication is distributed under the terms of Article $25 \mathrm{fa}$ of the Dutch Copyright Act, indicated by the "Taverne" license above, 


\section{RETENTION OF \\ NEW BLOOD DONORS}

Implications for interventions 


\section{RETENTION OF NEW BLOOD DONORS}

Implications for interventions

Proefschrift

ter verkrijging van de graad van doctor aan de Universiteit Maastricht, op gezag van de Rector Magnificus, Prof dr. L.L.G. Soete volgens het besluit van het College van Decanen,

in het openbaar te verdedigen

op maandag 9 december 2013 om 14.00 uur

Anne van Dongen Torman 
Promotores

Prof. dr. S. C. S. Abraham (University of Exeter, United Kingdom)

Prof. dr. R. A. C. Ruiter

Copromotor

Dr. I. J. T. Veldhuizen (Sanquin Research)

\section{Beoordelingscommissie}

Prof. dr. G. Kok (voorzitter)

Prof. dr. E. Ferguson (University of Nottingham, United Kingdom)

Dr. K. Massar

Prof. dr. P. Sheeran (University of North Carolina at Chapel Hill, USA)

Prof. dr. H. de Vries

The research reported in this thesis was funded by Sanquin Blood Supply.

\section{Contents}

Chapter 1 Introduction

Chapter 2 Are lapsed donors willing to resume blood donation, and what determines their motivation to do so?

Chapter 3 The influence of adverse reactions, subjective distress, and anxiety on retention of first-time blood donors

Chapter 4 Predicting blood donation maintenance: the importance of planning future donations

Chapter 5 Does questionnaire distribution promote blood donation? An investigation of question-behaviour effects

Chapter 6 General discussion

Reference List

Summary

Samenvatting

Dankwoord 
Introduction

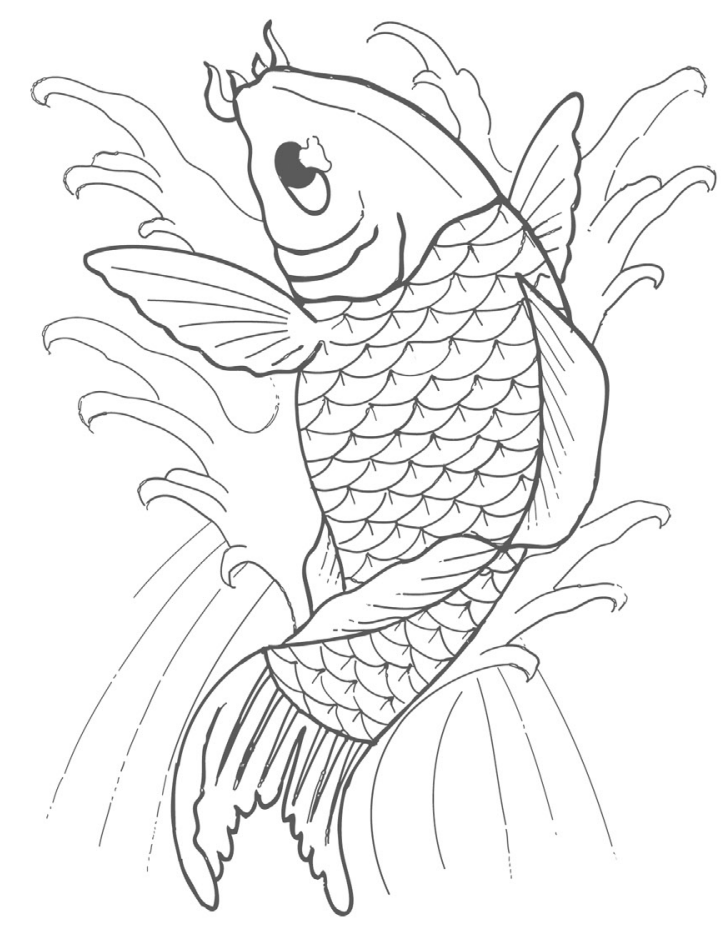




\section{Background}

Stable national blood supplies from donated human blood are essential to healthcare services worldwide. Artificial blood substitutes might become alternatives to human blood donation in the future, but such substitutes are still in early stages of development and will therefore probably not be available for years (Seifried, Klueter Weidmann, Staudenmaier, Schrezenmeier, Henschler, et al. 2011). Models that predict demographic developments paint a bleak picture for the future balance of blood demand and supply (Greinacher, Fendrich, Alpen and Hoffmann, 2007; Ali, Auvinen \& Rautonen, 2010; Seifried et al, 2011; Greinacher, Fendrich and Hoffmann, 2010). The aging population will cause problems with both blood supply and demand. Complex therapeutic procedures like haematopoietic stem cell transplantation, cardiovascular surgery and solid organ transplantation are options for an increasing proportion of older patients nowadays. These procedures will lead to a higher demand for donor blood and blood products. Assuming stable rates per age group until 2020, compute models predict that the demand for in-hospital blood transfusions will increase by approximately $25 \%$ while blood donations will decrease by approximately $27 \%$. The resulting, predicted shortfall is $47 \%$ of the demand for in-hospital patients (Greinacher Fendrich, Brzenska, Kiefel, and Hoffmann, 2011).

In the Netherlands, approximately 540,000 whole blood donations are required annually. These are provided by less than 400,000 donors. The average number of donations per year for a Dutch whole blood donor is 1.63. The proportion of regular donors (those who donate at least once a year), compared to first-time donors, is higher in the Netherlands than in many other Western countries (Veldhuizen \& Wagenmans, 2010). In spite of this relatively comfortable position, the national (and only) blood collection establishment, Sanquin, reports that each year 10\% of Dutch donors quit donating. Half of these withdrawals are mandatory, for example because the donor has reached the age of 70 , or for medical reasons like cancer and cardiovascular problems. The other half of these withdrawing donors resign for voluntary, non-medical reasons (Sanquin eProgesa, unpublished data). In the Netherlands, unlike many other countries, active blood donors receive written donation invitations from the blood bank to donate blood within a specified 2-week walk-in period at a time that is convenient to them. Some donors inform Sanquin that they are no longer willing to donate. Other donors stop responding to invitations without explicitly quitting their donorship. These non-responding donors are contacted after two missed invitations, but when they have missed five calls they are marked as stopped donors.

\section{Donor recruitment}

To ensure an adequate blood supply, blood banks constantly seek to recruit new donors. A survey sent to 48 European blood collection establishments in 37 countries 
revealed that recruitment activities in general have had limited success. This is often due to the a-theoretical approach when designing these campaigns. Most establishments recruit new donors by using leaflets, recruitment in large companies, awareness programs in school and commercials on local radio. These recruitment strategies are seldom based on a systematic assessment of factors (that is modifiable determinants) that influence non-donors to donate (Veldhuizen, Folléa, Degiorgio, Bart, Fontana, Tschaggelar et al. 2010). Although leaflets are the most widely used recruitment tools, a study found that these leaflets are mainly aimed at knowledge transfer. They do not target the psychological antecedents necessary to motivate people to sign up as a blood donor, and therefore do not reach the effect they are aiming for (Lemmens, 2009).

The Theory of Reasoned Action (TRA, Ajzen \& Fishbein, 1980) and the extended version, the Theory of Planned Behaviour (TPB, Ajzen, 1991), have been found to be useful models of modifiable determinants of donation. The TPB states that one's intention to perform a behaviour is the most proximal determinant of that behaviour. Intention, in turn, is predicted by attitude, subjective norm, and perceived behavioura control. Attitude refers to a person's overall evaluation of the outcome of the target behaviour. Subjective norm refers to a person's beliefs concerning significant others' approval or disapproval of the behaviour. Perceived behavioural control refers to a person's beliefs regarding the degree of control they will have over performance of the target behaviour. Self-efficacy is sometimes added to the TPB, and refers to a person's confidence and perceived ability to perform the behaviour successfully. Psychological antecedents of blood donation intentions have been modelled successfully using the TRA and TPB (Armitage \& Conner, 2001; Lemmens, Abraham, Hoekstra, Ruiter, de Kort, Brug \& Schaalma, 2005; Godin, Conner, Sheeran, Belanger-Gravel \& Germain, 2007; France, France \& Himawan, 2007; Lemmens, Abraham, Ruiter, Veldhuizen, Dehing, Bos \& Schaalma, 2009). Despite these positive results, the TPB is not a behavioural change theory. It was developed to predict and understand conscious behaviour by revealing the most important determinants of that behaviour.

In addition to the TPB determinants, awareness of the need for blood, social pressure and altruism are often named as motivators to become a blood dono (Piliavin, 1990; Glynn, Kleinman, Schreiber, Zuck, Mc Combs, Bethel, et al., 2002). Barriers include fear (of needles, blood, fainting or pain), apathy or low involvement, inconvenience and medical reasons (Oswalt, 1977; Lemmens et al, 2005; Bednall \& Bove, 2011).

Previous work has identified potentially effective donor recruitment strategies in the Netherlands. Most notably, a 'donors recruiting new donors' campaign was implemented and tested. Almost $60 \%$ of donors who were approached were willing to participate in such a campaign. They received a 'donors-recruiting new donors' leaflet and postcards facilitating donor registration. Donor recruitment was tested after 1-week and 6-week follow up. A field study revealed that 59\% of donors participating in the 'donors recruiting new donors' campaign reported asking at least one person to consider blood donation, compared to $38 \%$ of donor who did not participate (Lemmens, Abraham, Ruiter, Veldhuizen, Bos, \& Schaalma, 2008; Lemmens, Ruiter, Abraham, Veldhuizen, \& Schaalma, 2010). Engaging donors in donor recruitment seems like an effective approach, especially if campaign materials successfully target recruitment motivation and facilitate effective action.

\section{Donor retention}

DOMAINE is a European Union funded project that aims to create a safe and sufficient blood supply, by comparing and recommending good donor management practice. Eighteen European blood establishments collaborated in the project, and agreed on definitions for donor retention. Donor retention is defined as preventing blood donors from lapsing and eventually becoming inactive. Lapsing donors were defined as those who donated at least once within the last 24 months, but not in the last 12 months. Inactive donors were defined as having not donated in the last 24 months (Veldhuizen Folléa, and De Kort, 2013). The aim of donor retention programmes is to motivate donors to maintain their donating behaviour regularly, provided they are medically eligible. The DOMAINE project has indicated two 'performance indicators' for successful donor retention. The first is the percentage of regular donors, compared to the percentage of first time donors. In the Netherlands, the donor population consists of $80 \%$ regular donors. The second is the percentage of inactive or lapsed donors in the database $(9.1 \%$ in the Netherlands; Follea, Veldhuizen, Redpath, Jarnig \& Kral, 2010)

Retention of current blood donors has some benefits over recruitment of new blood donors. First, studies show that the risk of transfusion transmitted viral infections (e.g. HIV, Hepatitis B and C) in the blood is higher in new donors than it is in current donors (Kakaiya, Jacobs, Pelletier, Morse \& Cable, 1986; Archer, Buring, Clark Ismay, Kenrick \& Purusothaman, 1992; Glynn, Kleinman, Schreiber, Busch, Wright \& Smith, 2000). This is because first-time donors have had longer periods to acquire infection than repeat donors, and they have not been previously screened. In addition, donors have a healthier lifestyle than non-donors, and therefore tend to avoid infections (Atsma, Veldhuizen, de Vegt, Doggen \& de Kort, 2011). Second, the mandatory medical screening every new blood donor goes through in order to tes eligibility for blood donation is both more costly and more time consuming than the regular medical donor screening.

\section{Motivators}

Studies on retention of blood donors have found several factors that are associated with continuation of donation behaviour. Altruism and prosocial values are often 
named as motivators (Bednall \& Bove, 2011). However, many researchers have questioned whether altruism is an actual motivator for behaviour, or a rationalization of more selfish motives (e.g. donating blood makes donors feel good about themselves (Oswalt, 1977; Piliavin, 1990)). Studies to investigate this hypothesis have provided evidence towards more 'egoistic' motives, as beliefs in personal rather than societal benefit predict actual future donation (Ferguson, Farrell, \& Lawrence, 2008). Anothe study found that donating blood was associated with feelings of warm glow, and found no evidence that they were motivated by empathic concerns (Ferguson, Taylor, Keatley, Flynn, and Lawrence, 2012).Therefore, blood donation campaigns should focus on benevolent rather than purely altruistic messages.

Other motivators named in the literature are moral and subjective norms (Oswalt, 1977; Ferguson, 1996; Masser et al., 2008) and the development of a donor role identity (Callero \& Piliavion, 1983; Piliavin, 1990; Ferguson, 1996; Masser et al., 2008).

\section{Barriers}

Research has also indicated several barriers to donating blood. One of the most commonly named, even for regular donors, is anxiety or fear (Piliavin, 1990; Masser et al., 2008; Bednall \& Bove, 2011). Fear can take many forms, like fear of needles, general nervousness, fear of reduced health after donating, or fear of fainting. Studies have indeed shown that pre-donation anxiety is related to experiencing vasovagal reactions (Meade, France, and Peterson, 1996; Ditto \& France, 2006a; Viar, Etzel, Ciesielski, Olatunji, 2010; Labus, France \& Taylor, 2000). In addition, anxiety is a correlate of attitudes towards donation in donors and non-donors (Lemmens et al., 2005; Masser, White, Hyde, Terry \& Robinson, 2009; Clowes \& Masser, 2012). However, until now, no study has found a direct effect of anxiety on blood donation behaviour.

nconvenience, lack of planning, waiting time and lack of reminders have all been named as barriers for retention (Piliavin, 1990; Ferguson, 1996; Masser et al., 2008 Bednall \& Bove, 2011). Donors in a study by Schreiber and colleagues named 'inconvenience' as the major barrier to donation (Schreiber, Schlumpf, Glynn, Wright, Tu \& King, 2006). Similarly, Nilsson Sojka and Sojka (2003) reported that laziness was the most self-reported obstacle to donating blood regularly.

Research has shown that an adverse reaction during or after donating blood strongly decreases subsequent donations. Most studies on adverse events measured vasovagal reactions. Vasovagal reactions are symptoms like dizziness and nausea, which are caused by a combination of tension, a drop in blood pressure and the insertion of a needle in the vein. For example, France and colleagues found that for every 1 point increase on the Blood Donation Reaction Inventory (Meade, France \& Peterson, 1996), the likelihood of return decreased by $4 \%$ (France, France, Roussos $\&$ Ditto, 2004). In 2005, France and colleagues found that of those donors who did not experience a vasovagal reaction, $64 \%$ returned for a next donation within one year whilst among donors who experienced light vasovagal reactions, only $40 \%$ returned for a next donation (France, Rader \& Carlson, 2005). Similarly, Newman, Newman Ahmad and Roth (2006) found that experiencing a vasovagal reaction decreased return rates by $34 \%$.

Reactions other than vasovagal reactions have not been studied in detail but many donors do report feelings of being tired following donation or experiencing needle reactions such as bruising or sore arm. Investigating the effect of specific adverse reactions on return rates, Newman and colleagues found that bruising had no effect, but fatigue decreased return rates by $20 \%$. In addition to the experience of a vasovagal reaction, temporary deferral for medical reasons, such as a low haemoglobin level, can also cause donors to lapse (Custer, Chinn, Hirschler, Busch \& Murphy, 2007). This effect is especially strong in first-time donors (Custer, Schlumpf, Wright, Simon, Wilkinson \& Ness, 2011).

\section{Interventions}

In a systematic review of interventions, Godin, Vezina-Im, Belanger-Gravel and Amireault (2012) point out that in over 40 years of research in blood donation, remarkably few studies have focussed on intervention studies. One area of exception is the study of adverse events, where detailed interventions to prevent vasovaga reactions have been developed (Ditto, France, Lavoie, Roussos, and Adler, 2003a; Ditto, Wilkins, France, Lavoie, and Adler, 2003b; Ditto \& France, 2006b; Ditto, France, Albert and Byrne, 2007; Ditto, Byrne, and Holly, 2009a; Ditto, France, Albert, Byrne, and Smythe-Laporte, 2009b; Hanson \& France, 2004; France, France, and Patterson, 2006; France, Ditto, Wissel, France, Dickert, Rader, et al., 2010; Newman, Tommolino, Andreozzi, Joychan, Pocedic, and Heringhausen, 2007; Wieling, France, Van Dijk, Kamel, Thijs, and Tomasulo, 2011). Applied muscle tension and water loading are intervention that can prevent vasovagal reactions. One intervention that could help prevent vasovagal reactions, and thus increase retention, is combining applied muscle tension with implementation intentions to maintain these exercises at every blood donation (Ferguson, France, Abraham, Ditto \& Sheeran, 2007). Implementation intentions are if-then plans ("If situation X arises, then I will initiate the goal-directed response $y$ "), aimed at translating intentions into behaviour (Gollwitzer, 1999). Besides maintaining exercises to prevent vasovagal reactions, action planning interventions like implementation intentions could be used to overcome barriers related to planning, or perceived inconvenience. Implementation intentions have proven to be effective in other areas besides blood donation (for an overview, see Gollwitzer \& Sheeran, 2006) but have not been tested yet to overcome barriers related to blood donation. However, the firs step should be to investigate whether planning and perceived inconvenience are actual barriers to donating blood, as opposed to retrospective rationalizations. 


\section{Retention of new donors}

From all newly recruited and tested donors in the Netherlands, $24.9 \%$ do not provide a second donation. In the Netherlands, new donors first sign up, then get tested for medical eligibility, and only when found eligible are they invited for a first blood donation. Most withdrawal occurs after signing up, but before the first donation. After that, $6.0 \%$ lapse after the first donation, 5.0\% after the second, $4.0 \%$ after the third and $3.4 \%$ after the fourth donation. The withdrawal declines further after the fourth donation until it steadies between 1 and 2 percent (Sanquin, eProgesa 2008 unpublished data). Schreiber and colleagues (2005) found that the number of donations that new donors made in their first year predicted long-term retention. The more donors donated in their first year, the more likely it was that they became regular donors (Schreiber, Sharma, Wright, Glynn, Ownby, Tu, et al., 2005). Previous studies have focussed on the theory behind this trend, and have found that after 4-5 donations, 'being a blood donor' becomes a 'role identity' (Callero, Howard, and Piliavin, 1987) Donor role identity refers to the match between being a blood donor and the person's self-concept, and is a predictor of future blood donation (Charng, Piliavin, \& Callero, 1988; Armitage \& Conner, 2001; Giles, McClenahan, Cairns, \& Mallet, 2004). Masser and colleagues (2008) identified stages referred to as initiation, maintenance, habit formation, habit and establishment of blood donor identity formation. Other research has also found that the motivating factors associated with first time donation are different from the factors associated with maintenance of the blood donation behaviour (Callero \& Piliavin, 1983). Another study found that donors' self-categorisation indicated a split between non-donors, first-time donors, occasional donors (2-4, median of 4 donations) and regular donors (5 or more donations) (Ferguson \& Chandler, 2005). Such research suggests that experiences at the first donation and in the first year of the donor career seem crucial for long term retention.

\section{The present thesis}

Not many determinant studies have investigated in depth which factors influence retention specifically in the apparently crucial first year of the blood donor career. In this thesis, we will focus on blood donors in the period from signing up until two years later. To summarize, this thesis describes the results of a research programme focusing on retention of new blood donors. We investigated donors at the beginning of their donor career, using longitudinal studies and repeated measurements to assess the causal role of predictors of continued donation. Ouestionnaires measuring cognitive determinants and other psychological factors were sent to new donors before their first appointment, one month after their first donation and one year after their first donation. These results were combined with behavioural data from the donor data base. These studies may help identify modifiable determinants of donation which could be targeted by interventions.
Firstly, we wanted to know why people who had donated at least once lapsed from donating. In addition, we also wanted to find out if these lapsed donors could be re-recruited and, if so, how we can motivate them. Therefore, we set out to discover what modifiable beliefs, attitudes and cognitions are predictive of the willingness to resume donation. The results of this study are described in chapter 2 .

The second study, described in chapter 3 , focused on the effects of vasovagal reactions, needle reactions and fatigue at the first blood donation on retention. From previous studies we know that vasovagal reactions decrease retention. However, no study has focussed on the effect of vasovagal reactions in new donors specifically. In addition, we investigated if fatigue and needle reaction had an effect on retention in first time donors. Since different donors react differently to certain barriers, we explored the effects of self-reported anxiety and subjective distress on retention, after the experience of an adverse reaction.

From previous research we know that past behaviour, intention, vasovagal reactions and deferral are all associated with donation behaviour in the immediate future. The third study described in chapter 4 investigated whether planning and anxiety, in addition to these known factors, influence retention. In addition, we explored factors that determine continuation decisions regarding repeated blood donations.

Finally, evidence suggests that sending questionnaires in itself can increase blood donation behaviour (Godin, Sheeran, Conner \& Germain, 2008). Answering questions may make a person's (positive) attitudes and intentions about a behaviour more salient, and therefore increase performance of that behaviour. Such "questionbehaviour effects" (QBEs) have been reported in laboratory and field studies (Sprott, Spangenberg, Block, Fitzsimons, Morwitz \& Williams, 2006; Dholakia, 2010). Consequently, it is possible that large scale questionnaire distribution could be used as a populationlevel intervention to increase blood donation. The fourth study, described in chapter 5 attempted to replicate previous success in generating increased blood donation by sending questionnaires to new and regular blood donors. We investigated whether QBEs could provide an effective and cost efficient approach to increasing donation in The Netherlands.

It should be noted that this thesis is primarily a collection of published articles. Most chapters were written as stand-alone pieces so some repetition is inevitable throughout the thesis. 


\section{2}

Are lapsed donors willing to resume blood donation, and what determines their motivation to do so?

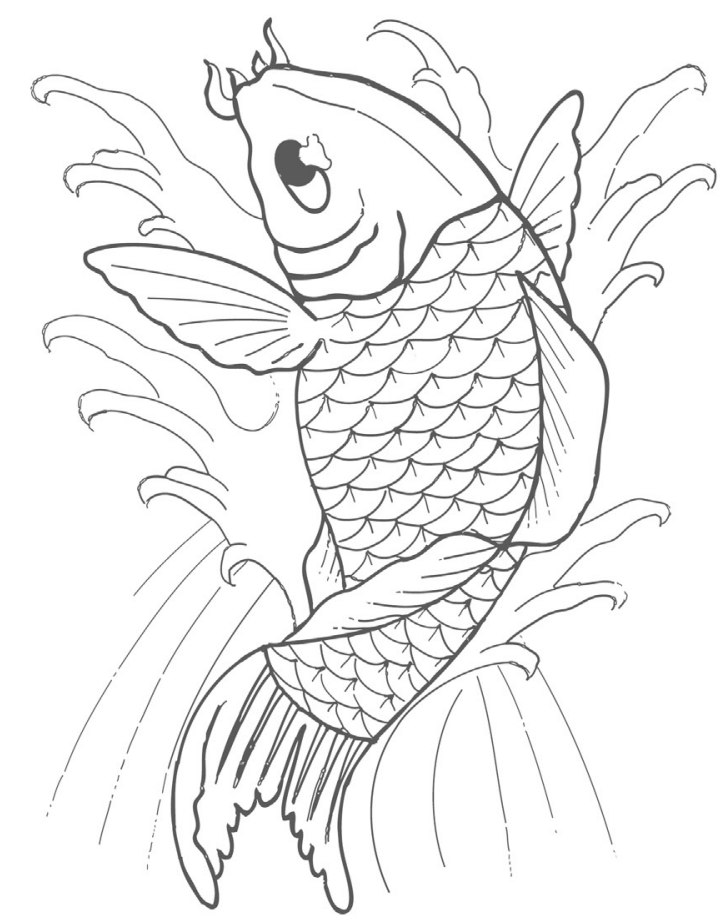

Published as: 


\section{Abstract}

Background: This study investigated the possibility of re-recruiting lapsed blood donors. Reasons for donation cessation, motivation to re-start donation, and modifiable components of donation motivation were examined. We distinguished between lapsed donors who had passively withdrawn by merely not responding to donation invitations and donors who had contacted the blood bank to actively withdraw.

Study Design and Methods: A cross sectional survey was sent to 400 actively lapsed donors and to 400 passively lapsed donors, measuring intention to restart donation, and psychological correlates of restart intention. The data were analysed using multiple regression analyses.

Results: The response rate among actively lapsed donors was higher than among passively lapsed donors (37\% versus $25 \%$ ). Actively lapsed donors typically ceased donating because of physical reactions, whilst passively lapsed donors quit because of a busy lifestyle. Nonetheless, $51 \%$ of actively lapsed responders and $80 \%$ of passively lapsed responders were willing to restart donations. Multiple regression analysis showed that cognitive attitude was the strongest correlate of intention to donate in the future $(\beta=.573, p<.001)$, with affective attitude $(\beta=.330, p<.001)$ and self-efficacy $(\beta=.248, p<.001)$ also explaining useful proportions of the variance.

Conclusion: The majority of lapsed donors indicated a moderate to high intention to restart donations. Interventions focussing on boosting cognitive and affective attitudes and self-efficacy could further raise such intentions.

\section{Introduction}

Internationally, blood donor pools are declining. This is a problem as many countries face increasing demand for blood supplies due to, in part, aging populations (Ali, Auvinen, \& Rautonen, 2010; Greinacher, Fendrich, Alpen, \& Hoffmann, 2007). To ensure adequate blood supply, blood banks seek to recruit new donors and retain current donors (Lemmens et al.,2005, 2009; Veldhuizen, Doggen, Atsma, \& De Kort, 2009; France, France, \& Himawan, 2007; Godin, Conner, Sheeran, Belanger-Gravel, \& Germain, 2007). Lapsed donors represent another source of blood supplies, yet we found no studies of the feasibility of re-recruitment of lapsed donors. Of course, some donors stop donating because of medical problems or old age and so are unlikely to resume donations. In many cases, however, we do not know why donors stop donating and whether they could be re-recruited. Recruitment of lapsed donors would have advantages over recruitment of new donors. First, there is a potential medical benefit because the risk of viral infections is much lower in regular donors than in first-time donors, and this reduced risk is maintained in donors who have not donated blood for 5 years (Archer et al., 1992; Glynn et al., 2000; Kakaiya et al., 1986; Schreiber, Glynn, Damesyn, Wright, Tu, Dodd, et al., 2003). Second, recruitment of lapsed donors may be less expensive because they have previously undergone mandatory medical testing procedures, including assessment of blood type.

To explore the possibility of re-recruiting lapsed donors, we set out to discover 1) why lapsed donors have ceased donations; 2) whether they are willing to resume blood donation; and 3) what modifiable beliefs, attitudes and cognitions are predictive of the willingness to resume donation. We expected this research to 1) provide an assessment of how worthwhile efforts to re-recruit lapsed donors would be and 2) what persuasive messages might be most effective in reactivating donation motivation in this group. Unsurprisingly, past donations and intentions to donate (that is, the degree of motivation to donate) are the strongest predictors of blood donation (Ferguson, 1996; Ferguson, et al., 2007; Masser et al., 2008). Lapsed donors have donated in the past but it is unclear how they could be motivated to do so again and although many studies have provided valuable insights for the development of retention and recruitment activities, their focus has been on either active donors or non-donors.

Psychological antecedents of donation intentions have been modelled successfully across studies (Lemmens et al.,2005, 2009; France et al., 2007; Godin et al., 2007; Armitage \& Conner, 2001; Veldhuizen, Ferguson, De Kort, Donders, \& Atsma, 2011) using the Theory of Planned Behaviour (TPB) (Ajzen, 1991). The TPB proposes that intention is predicted by attitudes, subjective norm, and perceived behavioura control. Attitudes refer to a person's overall evaluation of the behaviour; for example, are the outcomes of the target behaviour (e.g., blood donation) likely to be good or 
bad. Subjective norm refers to a person's beliefs concerning significant others' approval or disapproval of the behaviour. Finally, perceived behavioural control refers to a person's beliefs regarding the degree of control they will have over performance of the target behaviour.

Although the TPB provides a good model of the correlates of blood donation among donors and non-donors (Lemmens et al.,2005, 2009; France et al., 2007; Godin et al., 2007; Armitage \& Conner, 2001), the construct of self-efficacy (Bandura, 1997), referring to a person's confidence and perceived ability to perform a behaviour successfully, has been found to be a stronger correlate of blood donation intentions than the TPB construct of perceived behavioural control (Giles et al., 2004). Studies have also shown that moral norm (Lemmens et al., 2005, France et al., 2007; Armitage \& Conner, 2001) and donor identity (Armitage \& Conner, 2001; Giles et al., 2004 Charng, Piliavin, \& Callero, 1988) are predictors of intentions to donate blood. Mora norm refers to a person's feeling that he or she should donate while donor identity refers to the match between donation and the person's self-concept. Consequently, an optimum model of the psychological precursors of donation intentions might include attitudes, subjective norm, self-efficacy, moral norm, and donor identity. In addition to these constructs, several studies have shown that the satisfaction, that is, the positive experience with previous donation experiences, has an important impact on the intention to donate in the future (France et al., 2007; Nguyen, Devita, Hirschler, \& Murphy, 2008; Schlumpf, Glynn, Schreiber, Wright, Randolph, Tu, et al., 2007).

In the Netherlands, unlike many other countries, active blood donors receive written donation invitations from the blood bank to donate blood within a specified 2-week walk-in period at a time that is convenient to them We anticipated identification of two sub-groups of lapsed donors: those who actively lapsed by informing the blood bank that they were no longer willing to donate, and those who simply stopped responding to invitations without explicitly withdrawing. We expected that these two groups (active versus passive lapsed donors) might have different reasons for withdrawal and therefore for resuming donation.

\section{Materials and methods}

\section{Participants and procedure}

Two random samples of 400 actively lapsed donors and 400 passively lapsed donors were selected from the Dutch donor database. All 800 lapsed donors received a crosssectional survey by postal mail, measuring reasons for cessation, intention to resume blood donation, and several psychological determinants found to be associated with intention to donate. A reminder was sent to those donors who did not return the questionnaire within 3 weeks.
A total of 331 lapsed donors completed and returned the questionnaire, a response rate of $41.4 \%$. Eighty-three participants who indicated that they ceased donation for medical reasons were excluded from the analyses, because the attempted re-recruitment among this group would be inappropriate. Of the remaining 248 participants, 148 actively stopped donating, while the other 100 participants had lapsed passively. The response rate among actively lapsed donors was considerably higher (37\%) than the response among passively lapsed donors (25\%). Actively lapsed donors had made more donations $(M=17.70$ donations, $S D=18.24)$ before ceasing their donor caree than passively lapsed donors ( $M=12.93$ donations, $S D=15.91)$. The mean age of the two groups was similar, 40.91 years for actively lapsed donors and 39.46 years for passively lapsed donors. Of actively lapsed responders, $66.2 \%$ were female versus 53.0\% among those who passively lapsed.

\section{Measures}

We adopted and adapted measures from previous studies of donor motivation (Lemmen et al., 2005; Conner \& Norman, 2005). Unless otherwise stated, questionnaire items used 7-point Likert response options, ranging from $1=$ completely agree to $7=$ completely disagree. Mean scores were used to represent multiple-item scales that showed sufficient internal consistency (Cronbach's alpha $[a]>$.60). Measures were coded so that higher scores represented stronger views favouring restarting blood donation.

Reason for withdrawal. Donors were asked in an open-ended question to indicate the most important reason for them to quit donating blood.

Intention to return. Four statements measured intention towards returning as a blood donor (i.e. "Do you intend to start donating blood again?", "Do you expect to start donating blood again?" (see Table 3 for Cronbach's alpha).

Affective attitude. Affective attitude toward returning as a blood donor was assessed by rating three bipolar statements on a 7-point scale (i.e. "unpleasant- pleasant").

Cognitive attitude. Cognitive attitude toward returning as a blood donor was also assessed by rating three bipolar statements on a 7-point scale (i.e. "useful - useless").

Self-efficacy. Three statements measured self-efficacy toward returning as a blood donor (i.e. "I am confident that I would be able to start donating blood again", "To what extent do you see yourself as capable of donating blood again?").

Subjective Norm. Three statements measured subjective norm toward returning as a blood donor (i.e. "Most people that are important to me, think I should start donating blood again")

Moral Norm. Three items were included to assess personal moral norm toward returning as a blood donor (i.e. "I feel a moral obligation to start donating blood again", "I feel a personal responsibility to give blood").

After receiving the questionnaire, 8 out of the 248 lapsed donors $(3.2 \%)$ returned to donate again at least once in the subsequent 2 years. This number is not large enough to analyse actual returning behaviour. 
Role Identity. Three statements assessing role identity were taken from Callero (1992) (i.e. "Blood donation is something I rarely even think about", "For me, being donor means more than just donating blood", "Blood donation is an important part of whol am")

Satisfaction. Overall satisfaction with the blood bank and the donation process was assessed by seven items covering friendliness of the staff, efficiency at the dono centre, waiting times and overall satisfaction with the organisation.

\section{Statistical Analysis}

We used SPSS (Version 18.0, SPSS, Chicago IL) to analyse the quantitative data.

Differences between actively and passively lapsed donors were tested with univariate analyses of variance (ANOVAs). We employed hierarchical multiple regression to analyse the relations between the correlates of the intention to restart donating blood. For both lapsed donor groups, all factors were entered stepwise.

\section{Results}

\section{Why did these donors cease donation?}

Table 1 presents the reasons for ceasing donating blood that the participants gave in an open-ended question. Only reasons that were named by at least 10 respondents are included in the table. When participants named more than one reason, all reasons were counted. Participants gave on average 1.36 reasons for ceasing their donor career. A large proportion of actively lapsed donors (18\%) identified physical reactions during or after donation as the main reason for quitting. In addition, venepuncture problems (13\%), limited physical fitness and/or general physical problems (12\%) and the mismatch between a busy lifestyle and the time it takes to donate blood (13\%) were often identified. For passively lapsed donors, a busy lifestyle and the time it takes to donate blood was the most common reason for ceasing donation (19\%). The report of general physical problems was also a commonly shared reason for withdrawal (14\%).

\section{Are lapsed blood donors willing to resume donations?}

On average, lapsed donors reported a high intention to resume donations. Intention was measured on a 7-point scale (so that the midpoint fell between 3 and 4). A majority of the respondents $(70 \%)$ rated their intention to resume donation as 4 or above. Additionally, almost half of all donors (49.8\%) reported an intention rated as 5 or above. Of passively lapsed donors, $86.9 \%$ scored 4 or higher, whereas $68.7 \%$ reported a 5 or higher. The group of actively lapsed donors reported weaker intentions to restart blood donation. Nonetheless, $58.8 \%$ scored 4 or higher and $37.2 \%$ scored 5 or higher. Thus many lapsed donors are willing to consider giving blood again.

\begin{tabular}{|c|c|c|c|}
\hline \multirow[t]{3}{*}{ Reason for lapsing named 10 times or more } & \multicolumn{2}{|c|}{ Type of lapse } & \multirow{2}{*}{$\sqrt{\text { Tot }} \sqrt{\overline{\bar{\nu}}}$} \\
\hline & Active & Passive & \\
\hline & $N(\%)$ & $\mathrm{N}(\%)$ & $N(\%)$ \\
\hline Busy life and/or donation takes too much time & $23(11 \%)$ & $26(19 \%)$ & $49(14 \%)$ \\
\hline $\begin{array}{l}\text { Physical reactions after donation (vasovagal } \\
\text { reactions and/or fatigue) }\end{array}$ & $37(18 \%)$ & $7(5 \%)$ & $44(13 \%)$ \\
\hline $\begin{array}{l}\text { Limited physical fitness and/or general physical } \\
\text { problems }\end{array}$ & $24(12 \%)$ & $19(14 \%)$ & $43(13 \%)$ \\
\hline Venepuncture problems & $26(13 \%)$ & $7(5 \%)$ & $33(10 \%)$ \\
\hline Distance to the donor centre & $17(8 \%)$ & $11(8 \%)$ & $28(8 \%)$ \\
\hline Limited opening hours of the donor centre & $15(7 \%)$ & $12(9 \%)$ & $27(8 \%)$ \\
\hline Pregnancy-related reasons & $8(4 \%)$ & $13(10 \%)$ & $21(6 \%)$ \\
\hline Being deferred before for a low haemoglobin level & $13(6 \%)$ & $7(5 \%)$ & $20(6 \%)$ \\
\hline Closing of the regular donation centre & $13(6 \%)$ & $7(5 \%)$ & $20(6 \%)$ \\
\hline Complaint or disagreement & $18(9 \%)$ & $\mathrm{o}(0 \%)$ & $18(5 \%)$ \\
\hline Not receiving invitations to donate anymore & ० (०\%) & $13(10 \%)$ & $13(4 \%)$ \\
\hline Donor ignored several invitations to donate & $1(1 \%)$ & $11(8 \%)$ & $12(4 \%)$ \\
\hline Donation-related anxiety & $8(4 \%)$ & $2(2 \%)$ & $10(3 \%)$ \\
\hline Total & $203(100 \%)$ & $135(100 \%)$ & $338(100 \%)$ \\
\hline
\end{tabular}

\section{Group differences and cognition scores}

Table 2 presents the means and standard deviations for actively and passively lapsed donors on all measures, as well as the results of the univariate ANOVAs testing differences between the two groups on these measures. Actively lapsed donors' intentions, self-efficacy and cognitive attitude scores clustered above scale midpoints (means are 4.1, 4.8 and 4.4 respectively). Affective attitude scored lower $(M=3.2$. Satisfaction with the blood bank and donation procedure was high $(M=5.3)$. Actively lapsed donors had fairly low subjective and moral norm and role identity scores (means are 2.5, 3.1 and 3.0 respectively).

In comparison with actively lapsed donors, passively lapsed donors held more favourable intentions, self-efficacy, affective and cognitive attitude towards resumption (means are 5.4, 4.2, 5.8 and 5.5 respectively), and satisfaction with the blood bank and donation procedure was similarly high $(M=5.4)$. Passively lapsed donors' subjective and moral norms and role identity scores clustered below scale 
Table 2 Differences between actively lapsed and passively lapsed donors

\begin{tabular}{lccl} 
& $\begin{array}{c}\text { Actively lapsed (N=148) } \\
\text { Mean (SD) }\end{array}$ & $\begin{array}{c}\text { Passively lapsed (N=100) } \\
\text { Mean (SD) }\end{array}$ & F value \\
\hline Age & $40.91(10.21)$ & $39.46(10.22)$ & 0.021 \\
\hline $\begin{array}{l}\text { Lifetime number of } \\
\text { donations }\end{array}$ & $17.70(18.24)$ & $12.93(15.91)$ & $4.508^{*}$ \\
\hline Intention & $4.06(1.68)$ & $5.38(1.65)$ & $37.323^{* *}$ \\
\hline Affective attitude & $3.24(1.41)$ & $4.25(1.50)$ & $28.567^{* *}$ \\
\hline Cognitive attitude & $4.79(1.63)$ & $5.85(1.42)$ & $27.777^{* *}$ \\
\hline Self-efficacy & $4.17(1.51)$ & $5.05(1.41)$ & $21.384^{* *}$ \\
\hline Subjective Norm & $2.47(1.41)$ & $3.09(1.77)$ & $9.209^{*}$ \\
\hline Moral Norm & $3.12(1.65)$ & $3.58(1.67)$ & $4.523^{*}$ \\
\hline Role identity & $3.04(1.36)$ & $3.20(1.36)$ & 0.715 \\
\hline Satisfaction & $5.34(1.07)$ & $5.42(1.07)$ & 0.363 \\
\hline${ }^{*} p<.05 ;{ }^{* *} p<.001$ & & & \\
& & &
\end{tabular}

midpoints (means are 3.1, 3.6 and 3.2 respectively). Passively lapsed donors had significantly higher intentions regarding restarting their donor career, higher self-efficacy, more favourable attitudes, and more favourable social and moral norms than actively lapsed donors ( $p$ 's <.05)

\section{Cognitive correlates of intention to resume donations}

Table 3 reports correlations between cognition measures for actively and passively lapsed donors. Self-efficacy, attitudes and norms were significant correlates of intention to resume donation for both groups, providing support for a TPB model of donation motivation. Correlations are generally higher among passively lapsed donors than among actively lapsed donors, especially the correlation between intention and self-efficacy (0.70 vs. 0.49).

\section{Regression analyses}

We employed hierarchical multiple regression to explore the relative importance of the correlates of intention for each group. For both lapsed donor groups, all factors were entered one by one, in a stepwise manner. Tables 4 and 5 show the regression statistics for each step.

For passively lapsed donors, at the first step, cognitive attitude was shown to explain $74 \%$ of variance in intention. The inclusion of affective attitude enhanced the model and explained another $5 \%$. The addition of self-efficacy also significantly improved the amount of variance explained to account for a further $4 \%$. The inclusion
Table 3 Correlations between cognition measures

\begin{tabular}{|c|c|c|c|c|c|c|c|c|c|}
\hline & & 1 & 2 & 3 & 4 & 5 & 6 & 7 & 8 \\
\hline 1. & Intention & .95 & $0.72^{* *}$ & $0.81^{* *}$ & $0.49^{* *}$ & $0.26^{*}$ & $0.18^{*}$ & 0.12 & 0.01 \\
\hline 2. & Affective attitude & $0.74^{* *}$ & .93 & $0.72^{* *}$ & $0.50^{\circ *}$ & $0.57^{* *}$ & $0.36^{* *}$ & $0.25^{*}$ & -0.04 \\
\hline 3. & $\begin{array}{l}\text { Cognitive } \\
\text { attitude }\end{array}$ & $0.87^{* *}$ & $0.66^{* *}$ & .85 & $0.46^{* *}$ & $0.27^{*}$ & $0.30^{* *}$ & 0.16 & -0.01 \\
\hline 4. & Self-efficacy & $0.70^{* *}$ & $0.64^{* *}$ & $0.54^{* *}$ & .70 & 0.13 & 0.03 & 0.01 & -0.15 \\
\hline 5. & Subjective norm & $0.36^{* *}$ & $0.73^{* *}$ & $0.30^{*}$ & $0.33^{* *}$ & .84 & $0.37^{* *}$ & $0.25^{*}$ & -0.04 \\
\hline 6. & Moral norm & $0.28^{*}$ & $0.39^{* *}$ & $0.38^{* *}$ & $0.39^{* *}$ & $0.43^{* *}$ & .80 & $0.30^{* *}$ & 0.00 \\
\hline 7. & Role identity & 0.18 & $0.39^{* *}$ & $0.27^{*}$ & $0.41^{* *}$ & $0.42^{* *}$ & $0.27^{*}$ & .62 & 0.05 \\
\hline 8. & Satisfaction & 0.04 & 0.07 & 0.09 & 0.04 & 0.03 & 0.09 & 0.10 & .76 \\
\hline
\end{tabular}

of the other variables into the regression model did not significantly add to the prediction of intention. Together all variables accounted for $85 \%$ of the variance in intention.

Table 4 Hierarchical regression of intention on the extended TPB variables: Passively lapsed donors

\begin{tabular}{llllllll} 
Step/variable & $\beta$ & $\beta$ & $\beta$ & $\beta$ & $\beta$ & $\beta$ & $\beta$ \\
\hline Cognitive attitude & $.862^{* *}$ & $.670^{* *}$ & $.639^{* *}$ & $.605^{* *}$ & $.628^{* *}$ & $.638^{* *}$ & $.641^{* *}$ \\
\hline Affective attitude & & $.300^{* *}$ & $.410^{* *}$ & $.239^{*}$ & $.236^{*}$ & $.261^{*}$ & $.266^{*}$ \\
\hline Subjective norm & & & -.123 & -.073 & -.053 & -.032 & -.035 \\
\hline Self-efficacy & & & & $.266^{* *}$ & $.256^{* *}$ & $.236^{* *}$ & $.231^{* *}$ \\
\hline Moral norm & & & & & -.056 & -.050 & -.047 \\
\hline Role identity & & & & & & -.092 & -.090 \\
\hline Satisfaction & & & & & & & -.034 \\
\hline$R^{2}$ & .744 & .797 & .803 & .847 & .849 & .856 & .857 \\
\hline$R^{2}$ change & .744 & .053 & .006 & .044 & .002 & .006 & .001 \\
\hline F change & $264.34^{* *}$ & $23.38^{* *}$ & 2.89 & $25.30^{* *}$ & 1.30 & 3.82 & 0.66 \\
${ }^{*} p<.05 ;{ }^{* *} p<.001$ & & & & & & &
\end{tabular}


For actively lapsed donors, at the first step, cognitive attitude was shown to explain $67 \%$ of variance in intention. The inclusion of affective attitude enhanced the mode and explained another $4 \%$. The addition of self-efficacy and subjective norm did not significantly add to the amount of variance explained, however, the addition of moral norm did, accounting for a further $1 \%$. The inclusion of role identity and satisfaction into the regression model did not add to the prediction of intention. Together al variables accounted for $72 \%$ of the variance in intention.

Table 5 Hierarchical regression of intention on the extended TPB variables Actively lapsed donors

\begin{tabular}{llllllll} 
Step/variable & $\beta$ & $\beta$ & $\beta$ & $\beta$ & $\beta$ & $\beta$ & $\beta$ \\
\hline Cognitive attitude & $.816^{* *}$ & $.618^{* *}$ & $.588^{* *}$ & $.576^{* *}$ & $.601^{* *}$ & $.601^{* *}$ & $.599^{* *}$ \\
\hline Affective attitude & & $.276^{* *}$ & $.355^{* *}$ & $.324^{* *}$ & $.345^{* *}$ & $.343^{* *}$ & $.343^{* *}$ \\
\hline Subjective norm & & & -.104 & -.092 & -.065 & -.065 & -.064 \\
\hline Self-efficacy & & & & .067 & .044 & .045 & .050 \\
\hline Moral norm & & & & & $-.118^{*}$ & $-.120^{*}$ & $-.119^{*}$ \\
\hline Role identity & & & & & & .010 & .008 \\
\hline Satisfaction & & & & & & & .026 \\
\hline$R^{2}$ & .665 & .703 & .710 & .713 & .724 & .724 & .724 \\
\hline$R^{2}$ change & .665 & .037 & .007 & .003 & .011 & .000 & .001 \\
\hline Fchange & $278.44^{* *}$ & $17.34^{* *}$ & 3.36 & 1.52 & $5.40^{*}$ & 0.04 & 0.31 \\
${ }^{*} p<.05 ;{ }^{* *} p<.001$ & & & & & & &
\end{tabular}

\section{Discussion}

Recruitment of lapsed donors could be a safe and relatively inexpensive way to increase the number of active blood donors. This study established that a substantia proportion of lapsed donors are willing to resume donation, that is, 37\% of actively lapsed responders and $69 \%$ of passively lapsed responders. The study further confirmed that the TPB, including moral norm, provided a good model of the motivation of lapsed donors to restart donation.

Most respondents named physical reactions and venepunctural problems after donation as reasons for ceasing donation. In addition, a busy lifestyle and genera physical fitness were mentioned. Actively lapsed donors ceased donating mainly because of physical reactions or venepuncture related problems. Passively lapsed donors mostly cited a busy life and the time it takes to donate blood as the main reasons for quitting donations. The fact that passively lapsed donors made fewer donations than actively lapsed donors before ceasing further supports their report that time-management was an issue for them

The results revealed that, in general, passively lapsed donors have fairly strong intentions to start donating blood again. In addition, they hold favourable attitudes toward returning as a donor, and their self-efficacy is high, indicating that they see themselves as capable of restarting donations. Typically, they have been very satisfied with donations done in the past and the blood bank in general. Actively lapsed donors reported less positive intentions, attitudes and norms.

The TPB model including moral norm explains a large proportion of the variance of intention to restart donation. The largest predictor, however, is cognitive attitude Research has demonstrated that attitudes can be changed, suggesting that attitude change interventions could prompt lapsed donors to resume donations (Petty \& Cacioppo, 1986). For example, emphasising how worthwhile donation is for those who need blood and how donation can make donors feel good about themselves could bolster lapsed donors' motivation to resume donation. Thus our findings recommend contacting lapsed donors, highlighting the benefits of donation.

In most other studies, self-efficacy was found to be significant predictor of intention to donate. In this study, self-efficacy only predicted a small amount of variance in passively lapsed donors, but not in actively lapsed donors. Self-efficacy shows a medium-level correlation with intention for this group (of 0.49 ) thereby explaining $24 \%$ of the variance in intention. The failure of self-efficacy to predict in the multivariate model is primarily due to the attitude measures accounting for more than $70 \%$ of the variance, so it is not that self-efficacy is not associated with intention, rather that it is a weaker correlate than attitudes.

The difference of explained variance between the two groups could be due to different histories. Passively lapsed donors who did not respond to invitations anymore, quit mainly because they felt too busy and had a higher intention to donate in future. Self-efficacy was a predictor of intention for these donors, possibly because the majority feels they would donate blood again if they felt able. Actively lapsed donors quit mainly because of physical reactions, and they have a lower intention to return. Self-efficacy was not a predictor for actively lapsed donors, possibly because the majority feels that it does not matter if they can or cannot donate blood, they simply do not want to donate anymore, given their past experience.

When we excluded attitude from the regression analyses, self-efficacy emerged as main predictor of intention, with subjective and moral norm adding smal percentages of explained variance in intention (results not reported here). Therefore, emphasising the ease with which donations can be resumed as well as others' approval could be helpful in campaigns to re-recruit lapsed donors. One potentially usefu approach to re-recruiting lapsed donors would be to conduct adapted motivationa 
interviews (Sinclair, Campbell, Carey, Langevin, Bowser, and France, 2010). Finally, donors might be helped to translate pro-donation intentions into actions using planning and implementation intention formation (Godin, Sheeran, Conner, Delange, Germain, Belanger-Gravel, et al., 2010). Further experimental intervention design and evaluation work is needed to identify the most effective behaviour change techniques (Bartholomew, Parcel, Kok, Gottlieb, \& Fernandez, 2011; Abraham \& Michie, 2008)

Passively lapsed donors had stronger intentions to restart donations than actively lapsed donors. They also reported more favourable attitudes, higher social and moral norms and a higher feeling of self-efficacy than actively withdrawn donors. In addition, actively lapsed donors often reported to have ceased donations because of a negative donation experience, for example, physical reactions. Therefore, interventions aimed at recruiting passively lapsed donors may be more effective. On the other hand, this group is typified by a busy life and have previously missed five consecutive invitation to donate. This raises questions about the sustainability of reactivation among these donors. Our study suggests that it may be worth initially targeting passively lapsed donors and perhaps considering targeting actively lapsed donors who did not withdraw for medical reasons. A trial with long-term follow up is required to evaluate the sustainability of donation among reactivated donors

We observed a fairly low response rate of $41 \%: 51 \%$ of the actively lapsed donors and $32 \%$ of the passively lapsed donors. This may mean that quite a high proportion of lapsed donors may not respond to re-recruitment campaigns. On the other hand intentions to restart were positive among those who returned the questionnaire suggesting that this group are amenable to re-recruitment. Even if only $30 \%-40 \%$ of actively lapsed donors could be re-recruited this would be a worthwhile return on campaign investment for blood banks.

In conclusion, we found that lapsed donors were willing to start donating blood again. Our data suggest that campaigns focusing on attitude change and enhancing self-efficacy may be most effective and that it is worth targeting actively and passively lapsed donors. Future research should test the feasibility and effectiveness of such campaigns. 


\section{3}

The influence of adverse reactions, subjective distress and anxiety on retention of first-time blood donors

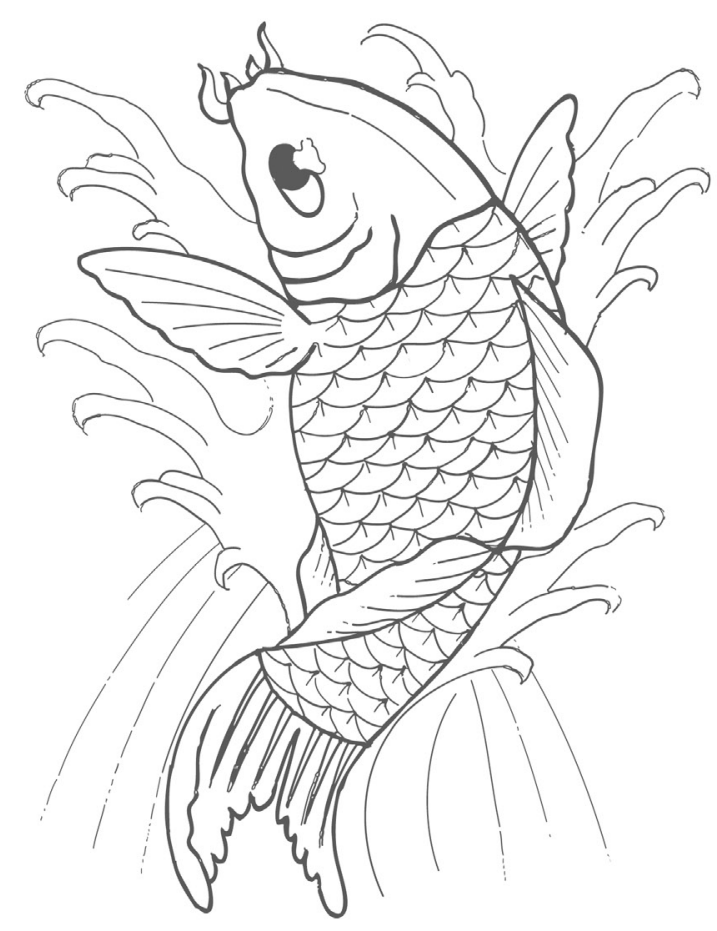

Published as:

Van Dongen, A., Abraham, C., Ruiter, R. A.C., \& Veldhuizen, I. J.T. (2013) The influence of adverse reactions, subjective distress, and anxiety on retention of first-time blood donors. Transfusion, 53, 337-343. 


\section{Abstract}

Background: This study investigated the effects of adverse events (i.e., needle reactions, fatigue and vasovagal reactions) and feelings of distress and anxiety on retention of first time blood donors. All effects were explored separately for men and women.

Study design and methods: First-time blood donors $(\mathrm{N}=2,438)$ received a questionnaire, asking them about their experience of adverse events, subjective distress and anxiety at their first donation. Provision of a second donation was checked approximately 18 months later. After exclusion of non-responders and donors who did not experience an adverse event, 1,278 first time donors were included in the logistic regression analyses.

Results: $9 \%$ of donors who experienced an adverse event at their first donation did not return for a second donation. Vasovagal reactions decreased retention in both males and females (men: $\mathrm{OR}=0.45 ; 95 \% \mathrm{Cl}=.23-.89$ and women: $\mathrm{OR}=0.71 ; 95 \% \mathrm{Cl}=$ $.51-.98)$. Fatigue decreased retention in males only $(\mathrm{OR}=0.62 ; 95 \% \mathrm{Cl}=.42-.91)$ subjective distress decreased retention in females only $(\mathrm{OR}=0.77 ; 95 \% \mathrm{Cl}=.65-.92)$. Conclusion: In addition to decreasing vasovagal reactions, retention interventions could productively target coping with fatigue and reducing subjective distress following adverse reactions.

\section{Introduction}

Stable national blood supplies are essential to healthcare services but aging populations are likely to reduce donor numbers in many countries (Ali, Auvinen, \& Rautonen, 2010; Greinacher et al., 2007). To prevent shortages in blood supplies, many blood establishments in Europe develop recruitment strategies to attract new donors and retention strategies to promote continuous donorship (Veldhuizen et al., 2010). The latter are important because in the Netherlands, for example, approximately $25 \%$ of donors do not provide a second donation (Sanquin, unpublished data). Van Dongen and colleagues (2011) found that more than half of the lapsed donors have no medical reason for ceasing donations. When asked for their reasons for ceasing blood donation, $13 \%$ of these voluntarily lapsed donors indicated to have quit because of physica reactions, and $10 \%$ because of needle reactions (Van Dongen, Abraham, Ruiter Schaalma, De Kort, Dijkstra, et al., 2012).

Research has shown that the experience of an adverse reaction, during or after donating blood, can decrease the retention of donors. Most studies investigating the effect of adverse reactions have focused on vasovagal reactions. Overall, experiencing a vasovagal reaction strongly decreases the likelihood to return for donation. France and colleagues (2004) found that for every 1 point increase on the Blood Donation Reaction Inventory (Meade, France, \& Peterson, 1996), the likelihood of return decreased by $4 \%$. In 2005, France, Rader, and Carlson found that of those donors who did not experience a vasovagal reaction, $64 \%$ returned for a next donation within one year, whilst among donors who experienced light vasovagal reactions, only $40 \%$ returned for a next donation. Newman and colleagues (2006) found that experiencing a vasovagal reaction decreased return rates by $34 \%$.

Vasovagal reactions are not the only adverse reactions that occur during or after blood donation. Many donors report feeling tired or experiencing needle reactions such as bruising or sore arm. Investigating the effect of specific adverse reactions on return rates, Newman and colleagues (2006) found that bruising had no effect, but fatigue decreased return rates by $20 \%$.

Adverse reactions may affect different groups of donors differently. Importantly, Veldhuizen and colleagues (2012) found that vasovagal reactions predicted withdrawa more strongly among male than female donors but, conversely, female donors (but not male donors) were more likely to withdraw following needle reactions such as bruising (Veldhuizen, Atsma, Van Dongen, and De Kort, 2012).

Newman and colleagues (2006) and Veldhuizen and colleagues (2012) provide the only available evidence on the retention effects of adverse reactions such as bruising. Both studies focused on regular blood donors, and no specifications were made for first-time versus return donors. Yet, Meade and colleagues (1996) and Newman and colleagues (2003) found greater withdrawal among first time donors versus regular 
donors (Meade et al., 1996; Newman, Pichette, Pichette, and Dzaka, 2003). Therefore, the current study focuses on the effect of vasovagal reactions, needle reactions and fatigue in new blood donors.

In addition, this study aims to find out which additional factors influence donor return once an adverse event does occur. If we design interventions taking these additional factors into account, we may be able to prevent blood donors from lapsing even if they do experience an unpleasant physical reaction at the donation.

Previous studies have shown that pre-donation anxiety is related to experiencing vasovagal reactions (Meade et al., 1996; Ditto \& France, 2006; Labus, France \& Taylor, 2000; Viar, Etzel, Ciesielski, \& Olatunji, 2010). We also know that anxiety is a correlate of attitudes towards donation in non-donors (Lemmens et al., 2005). Adverse reaction are unpleasant for all donors, but pain and discomfort experienced and the impact on future donation is likely to differ between donors. Angst and colleagues (2010) found that subjective distress was the most significant predictor of treatment seeking for several psychological disorders (Angst, Gamma, Clarke, Ajdacic-Gross, Rossler, and Regier, 2010) and it is known that expectations influence the subjective experience of pain (Koyama, McHaffie, Laurienti, \& Coghill, 2005). In addition, pain-related emotions influence pain perception and the desire for relief (Rainville, Bao, \& Chretien, 2005) Therefore, not just the actual experience of the adverse reactions, but also the subjective distress caused by the reaction could influence future donation behaviour.

The aim of the present study is to investigate the impact of vasovagal reactions, needle reactions and fatigue on retention of first-time blood donors. We also explored the effects of self-reported anxiety and subjective distress on retention, after the experience of an adverse reaction.

\section{Methods}

\section{Participants and Procedure}

Figure 1 shows how the sample was selected, illustrating inclusion and exclusion at various points in the Dutch registration and donation procedure. In the Netherlands, as well as in some other European countries (Italy, Denmark, Norway, Sweden), donors initially register via postal mail or email and then make an appointment for a medical, donor-eligibility check. At this first appointment, blood is tested but no donations are taken. Eligible donors are subsequently invited to attend to make their first donation.

We included all those who registered as a blood donor between August 2008 and April 2009 in The Netherlands. Participants received a first questionnaire by posta mail measuring pre-donation anxiety one week before their medical check ( $N=4,861$ response rate $64 \%$ ). Those who went on to make a first donation received a second questionnaire, again by postal mail, one month after their donation $(N=2,438)$. This
Figure 1 Flowchart of participants and procedure

\begin{tabular}{|c|c|}
\hline $\begin{array}{l}\text { New donor signs up via } \\
\text { postal mail or internet }\end{array}$ & \\
\hline & \\
\hline $\begin{array}{l}\text { Appointment }{ }^{\text {st }} \text { medical } \\
\text { check is made }\end{array}$ & \\
\hline & \multirow{2}{*}{$\begin{array}{l}\text { Exclu ded: } \\
\text { - Living near blood bank that is open <once a month } \\
\text { - Donor has donated previously }\end{array}$} \\
\hline Enrollment & \\
\hline & \\
\hline $\begin{array}{l}\text { Received } 1^{\text {st }} \text { questionnaire } \\
\qquad N=4,861\end{array}$ & \multirow{2}{*}{$\begin{array}{l}\text { Excluded: } \\
\text { - Non-responders } N=1,738 \\
\text { - Responded after deadline } N=159\end{array}$} \\
\hline & \\
\hline $\begin{array}{l}\text { Medical check at blood bank: } \\
\text { medical questionnaire and } \\
\text { blood sample }\end{array}$ & \\
\hline & \\
\hline $\begin{array}{l}\text { Blood sample is tested and } \\
\text { donor receives an invitation } \\
\text { for the } 1^{\text {st }} \text { blood donation }\end{array}$ & \\
\hline & \multirow{3}{*}{$\begin{array}{l}\text { Excluded: } \\
\text { - No } 1^{\text {st }} \text { donation } N=526 \\
\text { - Non-eligible donors } \\
\text { - Did not attend }\end{array}$} \\
\hline $1^{\text {st }}$ blood donation & \\
\hline & \\
\hline $\begin{array}{l}\text { Received } 2^{\text {nd }} \text { questionnaire } \\
\qquad N=2,438\end{array}$ & $\begin{array}{l}\text { Excluded: } \\
\text { - Non-responders } N=548\end{array}$ \\
\hline & Excluded: \\
\hline Analyses $N=1,278$ & $\begin{array}{l}\text { - No invitation for } 2^{\text {nd }} \text { donation } N=15 \\
\text { - No adverse events } N=597\end{array}$ \\
\hline
\end{tabular}

questionnaire measured adverse events, post-donation anxiety, and subjective distress. A total of 1,890 donors (response rate $78 \%$ ) completed the questionnaire. A small number of donors were lost to the study because they did not receive an invitation for their second donation due to an administrative error $(\mathrm{N}=15)$. Of the 1,875 remaining participants, $68 \%(\mathrm{~N}=1,279)$ experienced at least one of the 11 adverse reactions that were measured and so constituted the study sample. 


\section{Measures}

Adverse reactions

Six items measuring adverse reactions were taken from the Blood Donation Reactions Inventory, developed by Meade and colleagues (1996). This inventory requires respondents to rate 11 subjective physiological reactions associated with blood donation on a five point scale, ranging from $1=$ not at all to $5=$ to an extreme degree This scale had a high level of internal consistency (Cronbach's alpha $[\mathrm{a}]=.93$ ) and has been shown to correlate significantly with phlebotomist ratings of donor reactions 5 . Following France and colleagues (2008), who showed that fewer items are also representative for measuring adverse physical reactions, we selected the 6 mos common vasovagal symptoms, including dizziness, headache, nausea, sweating, hyperventilation and fainting (Cronbach's alpha for all six items was .77), and took the mean of the scores on these items. Furthermore, we measured four consequences of needle insertion (bruising, bleeding, pain and a tingly feeling in the arm) and took the mean of the scores on these items. Fatigue was measured with one item. We included only donors who scored 2 or higher on one or more of the 11 adverse events.

\section{Anxiety}

Pre-donation anxiety was measured one week before the first medical check. Three items measured anxiety on a seven point Likert scale, ranging from $1=$ completely disagree, to 7 = completely agree. The items used were: "I am afraid of needles", "I am nervous and/or tense about blood donation" and "Sometimes I am afraid of feeling faint and/or fainting at a blood donation". This scale was reliable (Cronbach's alpha (a) $=.72$ ) and mean scores were calculated to measure anxiety. In the second questionnaire, post-donation anxiety was measured again with the same items $(a=68)$. Since post-donation anxiety is likely to be dependent on the level of pre-donation anxiety, we used the difference between the two mean scores as an indicator of anxiety due to the donation experience.

\section{Subjective distress of adverse reactions}

Subjective distress was measured with one item on a 7-point scale ( $1=$ not unpleasant at all, 7 = extremely unpleasant): "How unpleasant did you find the occurrence of the physical reaction(s)?".

\section{Second donation}

As a measure of retention, we looked at whether or not a second donation was made by December 2010. This gave donors approximately 1.5 years to return for their second donation. Since some fairly common deferral reasons (colonoscopy, tattoo etc.) require a deferral period of y year, we decided to give the donors a sufficient amount of time to return. We extracted donation records from the donor database (eProgesa) to determine this.

\section{Statistical Analysis}

Statistical analyses were performed with SPSS (Version 19.0, SPSS, Chicago IL). Of all donors who reported having experienced any of the 11 adverse reactions, $30 \%$ did not fill in the subjective distress scale. Therefore, we imputed missing data using the multiple imputation procedure in SPSS. Multiple imputations of missing values, as opposed to single imputation, leads to unbiased estimates of associations and correctly estimated standard errors and confidence intervals (Donders, Van der Heijden, Stijnen, \& Moons, 2006). We created 20 imputed datasets. Each data set was analysed and we report the pooled results using Rubin's (1987) rules.

Chi squares were calculated to determine whether donors who experienced an adverse event had a lower return rate than donors who did not experience such an event. We employed logistic regressions to study which factors influenced whethe donors who experienced at least one adverse event made a second donation or not We ran all analyses separately for males and females. First, we ran univariate analyses on all measures. Second, we entered needle reaction, vasovagal reaction, fatigue, subjective distress and delta-anxiety in a multivariate logistic regression, controlling for age. The results were reported as odds ratios (OR), including the corresponding $95 \%$ confidence interval $(95 \% \mathrm{Cl})$.

\section{Results}

Response rates for both questionnaires were $64 \%$ and $72 \%$ respectively. Table 1 shows the return rates for donors who did or did not experience an adverse event. An omnibus analysis found no statistically significant difference in retention between donors who experienced any of the 11 adverse events versus those who did not experience any adverse event $\left(x^{2}=0.78, p=.433\right)$. Separate analyses for the different categories of adverse events found, however, a significant difference between donors who experienced a vasovagal reaction and those who did not $\left(x^{2}=8.85, p=.004\right)$. A significant difference was also found between those who experienced fatigue and those who did $\left(x^{2}=8.789, p=.004\right)$. We did not find a difference in retention between needle reaction and no needle reaction $\left(x^{2}=.05, p=.871\right)$ 
Table 1 Return rates and chi square analyses for donors who experienced an adverse event and those who did not

\begin{tabular}{lccc} 
& Second donation & $\boldsymbol{X}^{2}$ & $\boldsymbol{p}$-value \\
$\begin{array}{l}\text { Any adverse event } \\
\text { Yes }\end{array}$ & $90.7 \%$ & & \\
No & $91.9 \%$ & 0.784 & .433 \\
\hline $\begin{array}{l}\text { Needle } \\
\text { Yes }\end{array}$ No & $91.2 \%$ & & \\
No & $91.0 \%$ & 0.047 & .871 \\
\hline $\begin{array}{l}\text { Fatigue } \\
\text { Yes }\end{array}$ & & & \\
No & $88.3 \%$ & 8.789 & .004 \\
\hline $\begin{array}{l}\text { Vasovagal } \\
\text { Yes } \\
\text { No }\end{array}$ & $92.5 \%$ & & \\
& & & \\
& $88.8 \%$ & 8.848 & .004 \\
& $92.7 \%$ & & \\
\hline
\end{tabular}

Table 2 shows descriptive data for male and female first-time donors who reported having experienced at least one adverse reaction. Nine percent did not return for a second donation. The return rate did not differ for men and women (92.5\% versus $\left.90.0 \% ; X^{2}=1.84, p=.175\right)$. A MANOVA showed that women reported a higher mean score than men on all three adverse events (needle: $F(1,1270)=15.05, p<.001$; fatigue: $F(1,1270)=18.93$, $p<.001$; vasovagal: $F(1,1270)=6.64, p=.010)$. On average, these adverse reactions caused medium levels of distress ( $M=3.20$ on a 7 -point scale). Women score higher on this scale than men ( 3.26 versus $3.03, \mathrm{t}(1277)=-8.94, \mathrm{p}<.001$ ) Anxiety increased after the first donation, for both men and women $(F(1,1268)=19.81$ $p<.001)$. No interaction was found between time and gender $(F(1,1268)=.728, p=.394)$

For men, univariate logistic regression analyses (Table 3) showed that, fatigue (OR = $0.45 ; 95 \% \mathrm{Cl}=.32-.63)$, vasovagal reactions $(\mathrm{OR}=0.24 ; 95 \% \mathrm{Cl}=.18-.32)$ and subjective distress $(\mathrm{OR}=0.62 ; 95 \% \mathrm{Cl}=.47-.80)$ decreased the odds of making a second donation. Needle reactions $(\mathrm{OR}=0.95 ; 95 \% \mathrm{Cl}=.65-1.38)$ and anxiety $(\mathrm{OR}=0.72 ; 95 \% \mathrm{Cl}=.50$ 1.03) failed to reach significance.

For women, needle reactions $(\mathrm{OR}=0.80 ; 95 \% \mathrm{Cl}=.69-.92)$, vasovagal reactions $(\mathrm{OR}=0.56 ; 95 \% \mathrm{Cl}=.49-.63)$ and subjective distress $(\mathrm{OR}=0.73 ; 95 \% \mathrm{Cl}=.63-.85)$ decreased the odds of retention. Fatigue $(\mathrm{OR}=0.90 ; 95 \% \mathrm{Cl}=.76-1.05)$ and anxiety $(\mathrm{OR}=0.90 ; 95 \% \mathrm{Cl}=.75-1.08)$ again failed to reach significance.
Table 2 Demographic and donation characteristics on pooled data*

\begin{tabular}{|c|c|c|c|c|}
\hline & $\begin{array}{c}\text { Men } \\
(\mathrm{N}=335,26 \%)\end{array}$ & $\begin{array}{c}\text { Women } \\
(\mathrm{N}=943,74 \%)\end{array}$ & $\begin{array}{c}\text { Total } \\
(\mathrm{N}=\mathbf{1 , 2 7 8 )}\end{array}$ & Statistics \\
\hline Age (years), mean* & 34.38 & 32.51 & 33.00 & $t=4.80^{a}$ \\
\hline Second donation made, $\mathrm{N}(\%)$ & $310(92.5 \%)$ & 849 (90.0\%) & $1,159(90.7 \%)$ & $x^{2}=1.84$ \\
\hline \multicolumn{5}{|l|}{ Adverse reaction, mean ${ }^{*}$} \\
\hline Needle reaction & 1.49 & 1.66 & 1.62 & $F=15.05^{\mathrm{a}}$ \\
\hline Fatigue & 1.39 & 1.50 & 1.47 & $F=18.93^{a}$ \\
\hline Vasovagal reactions & 1.78 & 2.12 & 2.03 & $F=6.64^{b}$ \\
\hline Subjective distress, mean* & 3.03 & 3.26 & 3.20 & $t=-8.94^{a}$ \\
\hline Pre-donation anxiety & 2.72 & 3.11 & 3.00 & $F=48.46^{a}$ \\
\hline Post-donation anxiety & 2.92 & 3.24 & 3.15 & $F=40.19^{a}$ \\
\hline Delta anxiety & 0.20 & 0.13 & 0.15 & $F=19.81^{a}$ \\
\hline
\end{tabular}

Delta anxiety

0.20

p $p<.0011^{b} p<.05$

The adverse reactions were measured on a 5 point scale, the distress and anxiety scores were measured on 7 point scales.

Table 3 Univariate logistic regression analyses on pooled data*, predicting the odds of making a second donation for male and female first-time donors

\begin{tabular}{lll} 
& $\mathbf{O R}^{+}$ & $\mathrm{Cl} 95^{+}$ \\
\hline Men & & \\
\hline Needle & 0.95 & $0.65-1.38$ \\
\hline Fatigue & 0.45 & $0.32-0.63$ \\
\hline Vasovagal & 0.24 & $0.18-0.32$ \\
\hline Subjective distress & 0.62 & $0.47-0.80$ \\
\hline Delta anxiety & 0.72 & $0.50-1.03$ \\
\hline Women & & \\
\hline Needle & 0.80 & $0.69-0.92$ \\
\hline Fatigue & 0.90 & $0.76-1.05$ \\
\hline Vasovagal & 0.56 & $0.49-0.63$ \\
\hline Subjective distress & 0.73 & $0.63-0.85$ \\
\hline Delta anxiety & 0.90 & $0.75-1.08$ \\
"Mean of 20 imputed datasets. & & \\
+OR=Odds Ratio, Cl= Confidence Interval & & \\
\end{tabular}


When all factors were entered as predictors of a second donation, separately for men and women, we found unique contributions for vasovagal reactions, fatigue and subjective distress. For both men and women, a higher score on vasovagal reactions decreased the odds of making a second donation. For men, the negative effect of experiencing a vasovagal reaction on making a second donation was found to be stronger than for women (men: $\mathrm{OR}=0.45 ; 95 \% \mathrm{Cl}=.23-.89$; women: $\mathrm{OR}=0.71 ; 95 \% \mathrm{C}$ $=.51-.98$; see also Table 4). For male donors, but not for females, greater post-donation fatigue decreased the odds of retention (men: $\mathrm{OR}=0.62 ; 95 \% \mathrm{Cl}=.42-.91$ ). A higher subjective distress decreased the odds of making a second donation only in females $\mathrm{OR}=0.77 ; 95 \% \mathrm{Cl}=.65-.92)$. Needle reactions and anxiety did not make significant independent contributions to retention in both men and women.

Table 4 Multivariate logistic regression analyses on pooled data*, predicting the second donation for male and female first-time dd

\begin{tabular}{|c|c|c|}
\hline & \multicolumn{2}{|c|}{ Adjusted (age) } \\
\hline & $\mathrm{OR}^{+}$ & $\mathrm{Cl} 95 \%+$ \\
\hline \multicolumn{3}{|l|}{ Men } \\
\hline Needle & 1.03 & $0.46-2.28$ \\
\hline Fatigue & 0.62 & $0.42-0.91$ \\
\hline Vasovagal & 0.45 & $0.23-0.89$ \\
\hline Subjective distress & 0.81 & $0.59-1.12$ \\
\hline Delta anxiety & 0.86 & $0.59-1.26$ \\
\hline \multicolumn{3}{|l|}{ Women } \\
\hline Needle & 1.02 & $0.75-1.37$ \\
\hline Fatigue & 1.07 & $0.89-1.27$ \\
\hline Vasovagal & 0.71 & $0.51-0.98$ \\
\hline Subjective distress & 0.77 & $0.65-0.92$ \\
\hline Delta anxiety & 0.94 & $0.78-1.13$ \\
\hline
\end{tabular}

\section{Discussion}

In this study, we found that of all responders who experienced an adverse reaction during or after their first blood donation, $9 \%$ did not return for a second donation. Retention rates observed in our sample are higher than those found in other studies.
France and colleagues (2005) and Newman and colleagues (2006) showed a decrease in retention of $20 \%$ to $34 \%$, respectively. In the Netherlands, donors receive invitations for donation. Perhaps receiving an invitation to donate motivated more people who did experience an adverse event to try donating again than if they had to motivate themselves. Also, we only examined first time donors. France and colleagues (2005) showed higher retention rates after an adverse event in first time donors than in experienced donors.

Women, on average, experienced more severe adverse reactions than men Women also scored higher on subjective distress, and reported more pre- and post-donation anxiety than men. For both men and women, a vasovagal reaction strongly decreased the odds of making a second donation. This finding is consistent with previous studies (France et al., 2004, 2005; Newman et al, 2006; Veldhuizen et al., 2012).

Our univariate analysis, but not our multivariate analysis, showed that needle reactions indicate a significant decrease in retention in women. In addition, $10 \%$ of lapsed donors in our 2011 study indicated to have quit because of venepuncture problems (Van Dongen et al., 2012). Veldhuizen and colleagues (2011) also found that the odds of stopping after a needle reaction increased in women. In contrast, Newman and colleagues (2006) found no effect but did not consider men and women separately.

Newman and colleagues (2006) found that fatigue decreased retention. We found that, in men, but not women, fatigue during or after donation was associated with the odds of retention. Thus interventions in relation to anticipation of fatigue may be most usefully targeted at male donors.

On average, the effect of vasovagal reactions and fatigue on withdrawal was stronger in men than in women. This is consistent with Veldhuizen and colleagues (2011) who found that, among regular donors women experience more adverse event than men but that these events were more likely to trigger withdrawal among men However, further research is needed to clarify the importance of such gender differences

We found that donors with higher scores on subjective distress were less likely to make a second donation. This finding has implications for retention interventions, which until now have focused on decreasing adverse events. Several studies have shown that adverse reactions can be reduced by implementing interventions focusing on muscle tension, water and caffeine loading (Dittoet al., 2003a; Ditto, Byrne, \& Holly, 2009; Ferguson et al., 2007; France, France, Kowalsky, \& Cornett, 2010a; Hanson \& France, 2004; Newman et al., 2007; Newman \& Siegfried, 2011; Tomasulo, Kamel, Bravo, James, \& Custer, 2011; Wieling et al., 2011). Our study suggests that theory- and evidence- based interventions which enhance coping with adverse events could also reduce withdrawal (Hanson \& France, 2009). These may be most effective when 
targeted on those most likely to experience high subjective distress. Hanson and France (2009) found that, compared with standard donation controls, donors receiving social support during the blood donation reported fewer pre-faint reactions and greater likelihood of donating again within the next year. Further investigation of social support for those mostly likely to experience distress following adverse reactions, and other interventions such as mindfulness stress-reduction techniques (Grossman, Niemann, Schmidt, \& Walach, 2004) is warranted.

Anxiety was not associated with retention in new blood donors. We also ran the analysis replacing the difference score of anxiety with post-donation anxiety. Also the level of post-donation anxiety was not associated with the odds of making a second donation in the multivariate analysis. This suggests that a focus on anxiety reduction alone may be unproductive in increasing retention.

A limitation of this study is that $30 \%$ of responders did not fill in the subjective distress item. After some explorative analyses, we concluded that these missings are probably missing not at random. Since we asked the donors: "If you experienced a physical reaction, how unpleasant did you find the occurrence of the physica reaction(s)?", we suspect that some of the respondents who did not fill in this scale possibly did not think their adverse event was severe. As a sensitivity analysis, we ran the logistic regression analysis on the complete cases only. The analyses showed the same pattern of results, that is, vasovagal reactions and fatigue decreased the odds of a second donation in males, and vasovagal reactions and subjective distress decreased the odds of donation in females. Also, we ran the logistic regression analysis after replacing all missings with 1 , signifying minimal distress. Again, the results showed the same pattern.

In conclusion, we found that vasovagal reactions decrease the odds that a donor, either male or female, returned for a second donation. Women experience more adverse events, but the effect of adverse events on retention was stronger in men Fatigue decreased the odds only for male donors. The effect of adverse events on subsequent donation in women was dependent on their subjective distress levels. These findings suggest that interventions to retain new blood donors should not only focus on avoiding vasovagal reactions, but also on coping with fatigue and subjective distress associated with any adverse event. 


\section{4}

Predicting Blood Donation

Maintenance: The Importance of

Planning Future Donations

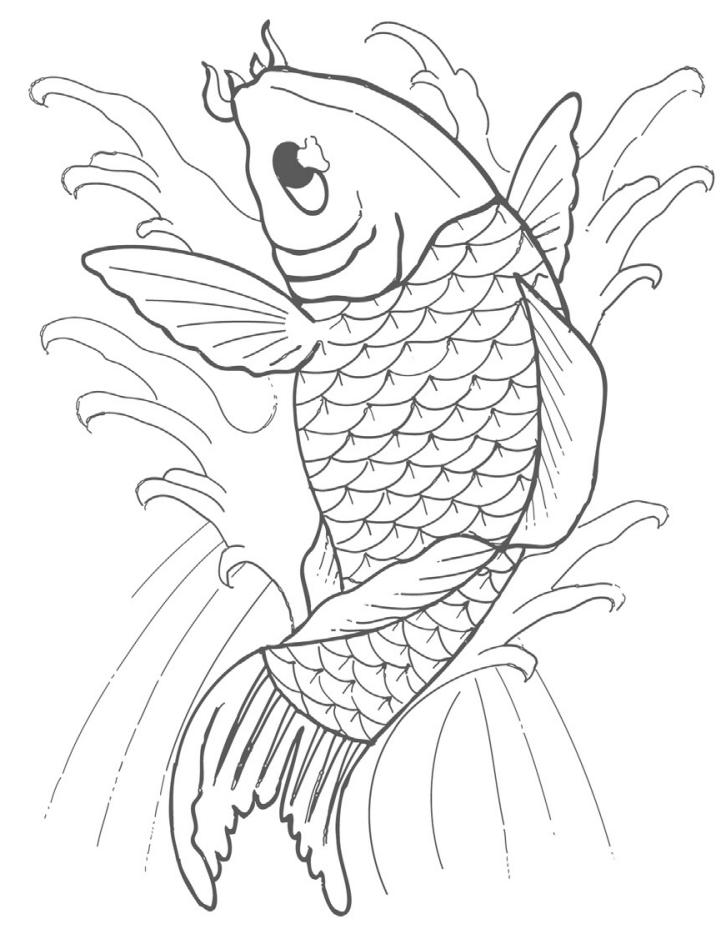

Published as:

Van Dongen A., Ruiter R., Abraham C., \& Veldhuizen I. (2013). 


\section{Abstract}

Background: Interventions to retain blood donors need to target the most influential and changeable factors. This study tested antecedents of three successive donation decisions.

Study design and methods: Participants were donors who had donated for the first time one year previous $(\mathrm{N}=1,018)$. Intention to continue donating, vasovagal reactions, deferral, anxiety and planning failure were measured. Analyses distinguished between 1) those who registered for donation following questionnaire completion, versus those who did not, 2) those who did or did not register for donation a second time following questionnaire completion, and 3) those who did or did not register for donation a third time following questionnaire completion

Results: Three logistic regression analyses showed that the first donation decision was influenced by intention $(\mathrm{OR}=1.70 ; 95 \% \mathrm{Cl}=1.30-2.21)$, number of donations made in the first year $(\mathrm{OR}=2.35 ; 95 \% \mathrm{Cl}=1.81-3.06)$, vasovagal reactions $(\mathrm{OR}=0.92 ; 95 \% \mathrm{Cl}$ $=0.87-0.97)$ and planning failure $(\mathrm{OR}=0.81 ; 95 \% \mathrm{Cl}=0.70-0.95)$. The second donation decision was influenced by intention $(\mathrm{OR}=1.44 ; 95 \% \mathrm{Cl}=1.06-1.95)$ and planning failure $(\mathrm{OR}=0.67 ; 95 \% \mathrm{Cl}=0.57-0.78)$, whilst the third decision was influenced only by planning failure $(\mathrm{OR}=0.85 ; 95 \% \mathrm{Cl}=0.73-1.00)$.

Conclusion: This indicates that for new donors, retention efforts should focus on the promotion of a positive intention and decreasing vasovagal reactions. However decreasing planning failure could be an even better investment since planning seem to determine long term retention. Possible behaviour change methods to reduce planning failure are discussed.

\section{Introduction}

Aging populations present a challenge for blood collection establishments. The eligible donor population is decreasing, whilst the amount of people needing blood or blood products increases (Greinacher et al., 2007; Ali, Auvinen and Rautonen, 2010). Consequently, evidence-based interventions to retain blood donors need to be designed and evaluated.

Factors found to predict blood donation consistently include past donation (Ferguson \& Bibby, 2002; Schreiber et al., 2005; Ferguson et al., 2007) and the intention to donate (Ferguson \& Bibby, 2002; Ferguson et al., 2007; Ferguson, 1996; Masser et al., 2008). Antecedents of intentions to donate blood have been studied using the Theory of Planned Behaviour (TPB, Ajzen, 1991) and several studies have found TPB variables to be good determinants of blood donation motivation and behaviou (Masser et al., 2008; Armitage \& Conner, 2001; Giles et al., 2004; Lemmens et al., 2005 France, France \& Himawan, 2007; Lemmens et al., 2009; Veldhuizen et al., 2011).

Even if we can increase donation intentions, this does not necessarily mean that donation behaviour will be changed. In a meta-analysis, Webb and Sheeran found that even medium-to-large changes in intention led only to small-to-medium changes in behaviour (Webb \& Sheeran, 2006). Therefore, donor-related factors other than intention need to be addressed in interventions designed to retain donors.

In an extensive review of donor retention studies, Masser and colleagues (2008) described two types of 'control': control of planning (time-management of a busy life), and personal control (control of anxiety, fear of needles, and vasovagal reactions). Other studies have also reported the importance of fear and anxiety in blood donation. Ferguson and colleagues state that anticipated emotions (especially anxiety) are important to a donors' decision to donate again (Ferguson et al., 2007). Nilsson, Sojka and Sojka found that fear of needles was the second most reported obstacle for donating blood (Nilson Sojka \& Sojka, 2003), and both Lemmens and colleagues (2005) and Clowes and Masser (2012) showed that fear of blood and needles was negatively associated with the attitude towards blood donation, both for donors and non-donors. However, until now, only one study has investigated the direct effect of anxiety on blood donation behaviour (Van Dongen, 2013). This study did not find a significant effect of anxiety.

Many studies have found that the experience of adverse events, especially vasovagal reactions, can decrease retention dramatically (Van Dongen et al., 2013; France et al., 2004; France, Rader \& Carlson, 2005; Newman et al., 2006; Veldhuizen et al., 2012). Moreover, temporary deferral for medical reasons, such as a low Hb level, can cause donors to lapse (Custer et al, 2007; Custer et al. 2011).

Regarding control of planning, a previous study amongst lapsed donors reported that the reason for withdrawal mentioned by most donors was a 'busy life and/or the 
time it takes to make a donation' (Van Dongen et al., 2012). Donors in Schreiber and colleagues' study named 'convenience' as the major barrier against donating (Schreiber et al. 2006). Related, Nilsson Sojka and colleagues (2003) notably reported that laziness was the most self-reported obstacle for donating blood regularly. However, these barriers were measured retrospectively, and do not clarify whether failure to plan a donation decreases subsequent donation behaviour.

In this prospective study, we investigated whether planning failure, vasovaga reactions, deferral, number of donations made in the first year of donating, and intention are associated with donation behaviour in the immediate future among donors one year after their first donation.

We also investigated whether these factors determine subsequent decisions to continue blood donation. Callero and Piliavin found that successive donation decision were affected by somewhat different factors, such that specific antecedents did no have the same effect on the decision to donate a first time as they had on decisions to donate a second or third time (Callero \& Piliavin, 1983). Therefore, we examined three successive donation decisions separately. We identified antecedents that distinguished between 1) those who registered for donation following completion of a questionnaire, versus those who did not, 2) those who did or did not register for donation a second time, following questionnaire completion and 3) those who did or did not register for donation a third time following questionnaire completion. We chose registration for donation instead of donation, because registration indicates willingness to donate.

\section{Methods}

\section{Participants and Procedure}

Participating donors were part of a longitudinal repeated measurement study on donor motivation during the first year of the donor career. The participants were extracted randomly from the national donor database of Sanquin Blood Supply. Sanquin is the only establishment in the Netherlands that is legally allowed to collect and supply blood and blood products. We included all those who registered as a blood donor between August 2008 and April 2009. Each participant was sent a first questionnaire before their first donation by postal mail, including an introduction letter explaining the aims and procedure of the study. Those who filled in and returned the questionnaire were sent an almost identical second questionnaire one month after their first donation. The only difference between the 2 questionnaires was the time framing of the questions. For example, an item measuring planning in the first questionnaire would state: "I expect I might sometimes forget invitations to donate blood", whilst the similar item in the second questionnaire would state: "I have forgotten invitations to donate blood in the past".
One year after their first donation, we sent these donors a third questionnaire, which was identical to the second questionnaire. The third questionnaire was used for the current study. This questionnaire was sent to 1,890 donors between August 2009 and December 2010. A response rate of $67 \%$ yielded 1,259 completed questionnaires. Since we recently found that plasma donors' motivation is distinct from whole blood donors' motivation (Veldhuizen \& Van Dongen, in press) we excluded plasma, other non-whole blood and autologous donors from the analyses $(N=151)$. We also excluded the donors who indicated on the questionnaire that they had withdrawn from blood donation $(N=90)$. This left 1,018 whole blood donors for analyses. Of these donors, 923 registered following completion of the questionnaire, 840 registered a second time, and 748 registered for a third time (see Figure 1).

\section{Questionnaire}

Unless otherwise stated, the items in the questionnaire used seven point Likert scales, ranging from $1=$ completely disagree, to $7=$ completely agree

Intention. Three statements measured intention towards donating regularly during the next two years ("I intend to donate blood regularly during the next 2 years", "I expect to donate blood regularly during the next 2 years", "It is likely that I will stil be a blood donor in 2 years"). This scale was reliable (Cronbach alpha $[a]=.90$ ).

Vasovagal reactions. Items measuring adverse events were taken from the Blood Donation Reactions Inventory developed by Meade and colleagues (Meade, France \& Peterson, 1996). This inventory required respondents to rate 11 subjective physiological reactions associated with blood donation. Each reaction was endorsed on a $1=$ not a all to $5=$ to an extreme degree scale. This scale has been shown to correlate significantly with phlebotomist ratings of donor reactions. Following France and colleagues, who showed that using fewer items is also representative for measuring physical reactions (France et al., 2008), we selected the 6 most common vasovagal symptoms, including dizziness, headache, nausea, sweating, hyperventilation, and fainting. The score on vasovagal reactions was calculated by adding the scores across 6 items, and thus could vary between 6 and 30 .

Medical deferral. One yes/no question assessed temporary deferral for donation ("Have you ever been temporarily deferred for donation?").

Anxiety. Three items measured anxiety ("I am afraid of needles", "I am nervous and/or tense about blood donation" and "Sometimes I am afraid of feeling faint and/or fain at a blood donation"; $a=.72$ ). A higher score meant more donation related anxiety.

Planning failure. Three items measured donors perceived ability to plan their donation in their daily life ("I have forgotten invitations to donate blood in the past", "In general, it is difficult for me to make the time to donate blood" and "After receiving an invitation, I have postponed my visit once or twice"; $a=.72$ ). A higher score meant a more negative evaluation ('failure') of their planning. 
Figure 1 Flowchart of participants, procedure and analyses

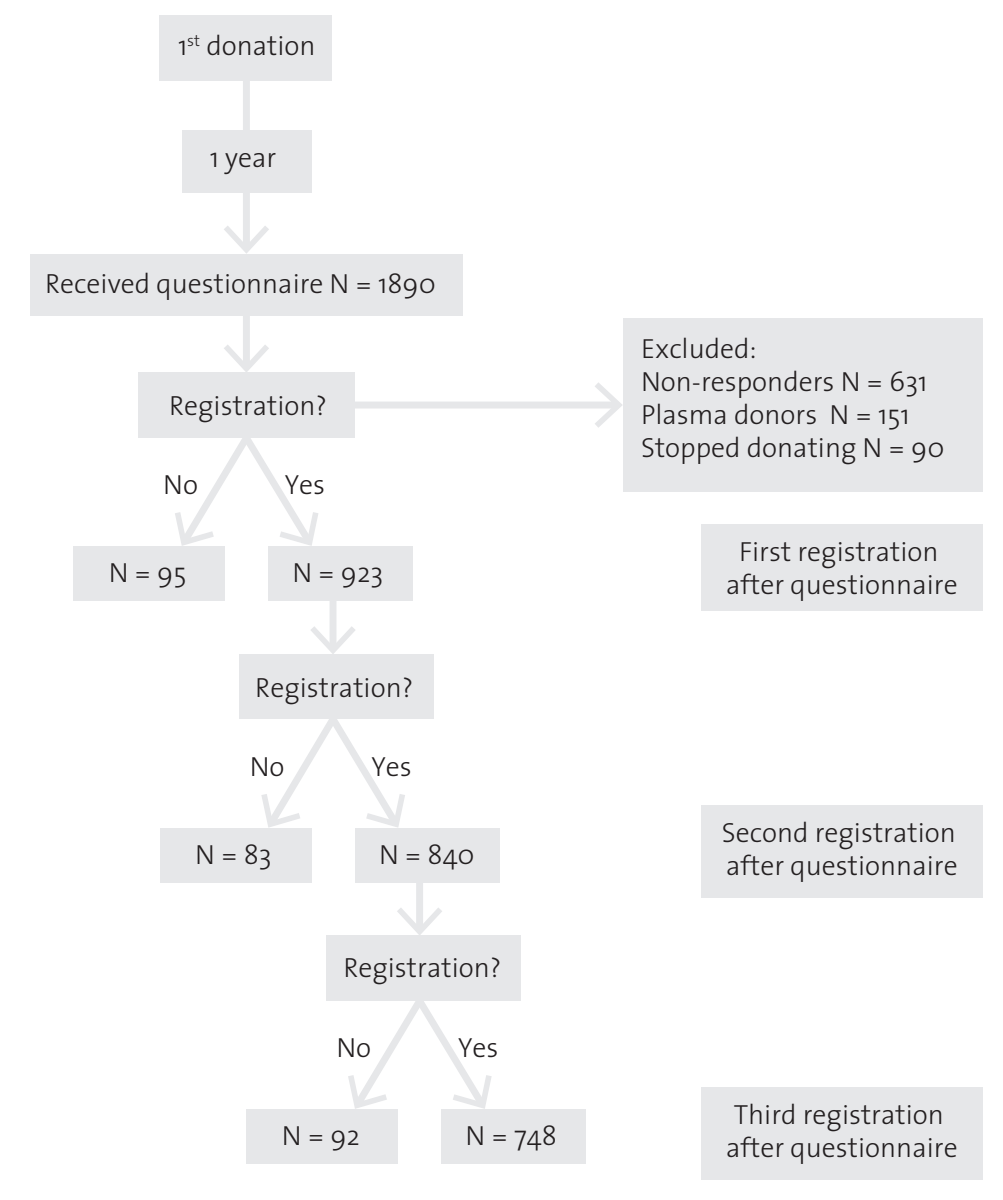

\section{Number of registrations for donation}

We calculated the number of registrations for donation donors made in their first year before receiving this study's questionnaire using the donor database (eProgesa). We also checked the number of whole blood registrations made by the donor after completion of the questionnaire until June 2012. This provided the main outcome measure, allowing us to distinguish between 1) those who registered for donation following questionnaire completion, versus those who did not, 2) those who did or did not register for donation a second time following questionnaire completion, and 3 ) those who did or did not register for donation a third time following questionnaire completion.

\section{Statistical analyses}

We used SPSS Version 19.0 (SPSS, Chicago IL) to analyse the data. Univariate and multivariate logistic regression analyses were employed to calculate the odds ratios on donating again, including $95 \%$ confidence intervals. The first logistic regression model calculated the odds of registering again compared to not registering again following completion of the questionnaire, the second logistic regression calculated the odds of registering twice compared to registering only once following questionnaire completion, and the third logistic regression calculated the odds of registering thrice compared to not registering only twice following questionnaire completion.

\section{Results}

\section{Sample Characteristics}

Table 1 shows that women were more likely to complete and return the questionnaire than men (68\% versus $32 \%$ ). The average age of the responders was 35.9 years old. On average, respondents had made 3.3 donations during their first year and $24 \%$ had been temporarily deferred at least once. Mean scores (and standard deviations) were 10.2 (out of a possible 30) for vasovagal reactions $(S D=4.3$ ) and 6.4 (out of $7, S D=0.8$ ) for intention. Anxiety and planning failure scores were relatively low (2.7 [1.5] and 2.5 [1.6], respectively).

\section{Correlations}

Table 2 presents the correlations between measures. The valence of the correlations was as expected. Intention to continue donation was negatively correlated with vasovagal reactions, anxiety and planning failure $(r=-.30, r=-.25$ and $r=-.32)$ and was positively correlated with number of donations made in the first year $(r=.21)$. Number of donations also showed a negative correlation with vasovagal reactions, anxiety and planning failure $(r=-.20, r=-.18$ and $r=-.21)$. Anxiety and vasovagal reactions were correlated $(r=.46)$. As men are allowed to donate more often than women, gender and number of donations were also correlated $(r=-.54)$.

\section{First donation decision}

Table $3 a$ and $3 b$ present the results of the univariate and multivariate logistic regressions calculating the odds of donating again following questionnaire completion compared to not donating again. Having a high intention following the first donation increased the odds of making a donation $(\mathrm{OR}=1.70 ; 95 \% \mathrm{Cl}=1.30-2.21)$, as well as the number of donations made in the first year $(\mathrm{OR}=2.35 ; 95 \% \mathrm{Cl}=1.81-3.06)$. Vasovaga reactions ( $\mathrm{OR}=0.92 ; 95 \% \mathrm{Cl}=0.87-0.97)$ and planning failure $(\mathrm{OR}=0.81 ; 95 \% \mathrm{Cl}=0.70$ -0.95 ) decrease the odds of donating. The OR for deferral failed to reach significance and anxiety did not affect the odds of donation. 


\section{Table 1 Sample Characteristics}

$N=1,028$

$35.9(12.66)$

Gende

Male
Female

$321(31.6 \%)$

Deferral

No

Yes

$728(71.5 \%)$

$245(24.1 \%)$

Number of donation

$3.3(1.18)$

Vasovagal reactions

$10.2(4.27)$

Intention

$6.4(0.80)$

Anxiety

$2.7(1.47)$

Planning failure

$2.5(1.56)$

Vasovagal reaction has a range of 6-30. Intention, anxiety and planning were measured on a 7 point scale.

Table 2 Correlations between measures

\begin{tabular}{|c|c|c|c|c|c|c|c|c|c|}
\hline & & 1 & 2 & 3 & 4 & 5 & 6 & 7 & 8 \\
\hline 1. & Age & - & $-.07^{*}$ & -.05 & $.09^{*}$ & $-.21^{* *}$ & $.15^{* *}$ & $-.16^{* *}$ & $-.21^{* *}$ \\
\hline 2. & Gender & & - & .05 & $-.54^{* *}$ & $.21^{* *}$ & -.01 & $.16^{* *}$ & $-.12^{* *}$ \\
\hline 3. & Deferral & & & - & -.05 & .03 & $-.09^{*}$ & .06 & -.03 \\
\hline 4. & \# donations & & & & & $-.20^{* *}$ & $.21^{* *}$ & $-.18^{* *}$ & $-.21^{* *}$ \\
\hline 5. & Vasovagal & & & & & - & $-30^{* *}$ & $.46^{* *}$ & $.15^{* *}$ \\
\hline 6. & Intention & & & & & & - & $-.25^{* *}$ & $-.32^{* *}$ \\
\hline 7. & Anxiety & & & & & & & - & $.20^{* *}$ \\
\hline 8. & Planning failure & & & & & & & & - \\
\hline
\end{tabular}

Table $3 a$ Univariate logistic regression analyses, calculating the odds of donating (1), compared to not donating (o) following questionnaire completion.

\begin{tabular}{|c|c|c|}
\hline & \multicolumn{2}{|c|}{ Adjusted (age \& gender) } \\
\hline & $\mathrm{OR}^{+}$ & $\mathrm{Cl} 95 \%^{+}$ \\
\hline 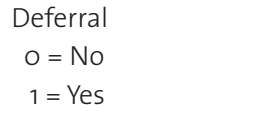 & 1.56 & $0.98-2.46$ \\
\hline Number donations & 2.81 & $2.24-3.54$ \\
\hline Vasovagal reactions & 0.88 & $0.85-0.92$ \\
\hline Intention & 2.50 & $2.00-3.13$ \\
\hline Anxiety & 0.76 & $0.66-0.86$ \\
\hline Planning failure & 0.67 & $0.60-0.76$ \\
\hline
\end{tabular}

Table $\mathbf{3 b}$ Multivariate logistic regression analyses, calculating the odds of donating (1), compared to not donating (o) following questionnaire completion.

\begin{tabular}{|c|c|c|}
\hline & \multicolumn{2}{|c|}{ Adjusted (age \& gender) } \\
\hline & $\mathrm{OR}^{+}$ & $\mathrm{Cl} 95 \%^{+}$ \\
\hline $\begin{array}{c}\text { Deferral } \\
0=\text { No } \\
1=\text { Yes }\end{array}$ & 1.49 & $0.87-2.56$ \\
\hline Number donations & 2.35 & $1.81-3.06$ \\
\hline Vasovagal reactions & 0.92 & $0.87-0.97$ \\
\hline Intention & 1.70 & $1.30-2.21$ \\
\hline Anxiety & 1.09 & $0.90-1.31$ \\
\hline Planning failure & 0.81 & $0.70-0.95$ \\
\hline
\end{tabular}

Second donation decision

Table $4 a$ and $4 b$ present the results of the univariate and multivariate logistic regressions calculating the odds of donating a second time following questionnaire completion, compared to donating only once. This time, only intention increased the odds of donation significantly $(\mathrm{OR}=1.44 ; 95 \% \mathrm{Cl}=1.06-1.95)$, whilst planning failure decreased the odds of making a donation $(\mathrm{OR}=0.67 ; 95 \% \mathrm{Cl}=0.57-0.78)$. Number of donations made in the first year failed to reach significance and vasovagal reactions and anxiety did not affect the odds of making a second donation. 
Table 4a Univariate logistic regression analyses, calculating the odds of donating more than once (1), compared to donating only once (o).

\begin{tabular}{|c|c|c|}
\hline & \multicolumn{2}{|c|}{ Adjusted (age \& gender) } \\
\hline & $\mathrm{OR}^{+}$ & $\mathrm{Cl} 95 \%+$ \\
\hline \multicolumn{3}{|l|}{ Deferral } \\
\hline $\mathrm{O}=\mathrm{No}$ & 1.67 & $1.02-2.73$ \\
\hline $1=$ Yes & & \\
\hline Number donations & 1.64 & $1.31-2.05$ \\
\hline Vasovagal reactions & 0.91 & $0.87-0.95$ \\
\hline Intention & 1.97 & $1.52-2.56$ \\
\hline Anxiety & 0.81 & $0.70-0.93$ \\
\hline Planning failure & 0.68 & $0.59-0.77$ \\
\hline
\end{tabular}

Table $4 \mathbf{b}$ Multivariate logistic regression analyses, calculating the odds of donating more than once (1), compared to donating only once (o).

\begin{tabular}{|c|c|c|}
\hline & \multicolumn{2}{|c|}{ Adjusted (age \& gender) } \\
\hline & $\mathrm{OR}^{+}$ & $\mathrm{Cl} 95 \%^{+}$ \\
\hline \multicolumn{3}{|l|}{ Deferral } \\
\hline $\mathrm{O}=\mathrm{No}$ & 1.63 & $0.96-2.77$ \\
\hline \multicolumn{3}{|l|}{$1=$ Yes } \\
\hline Number donations & 1.10 & $0.83-1.47$ \\
\hline Vasovagal reactions & 0.96 & $0.91-1.02$ \\
\hline Intention & 1.44 & $1.06-1.95$ \\
\hline Anxiety & 1.03 & $0.85-1.23$ \\
\hline Planning failure & 0.67 & $0.57-0.78$ \\
\hline
\end{tabular}

\section{Third donation decision}

Table $5 \mathrm{a}$ and $5 \mathrm{~b}$ present the results of the univariate and multivariate logistic regressions comparing the odds of donating more than twice following questionnaire completion, compared to donating only twice. Only planning failure predicted a significant change in the odds of the third donation $(\mathrm{OR}=0.85 ; 95 \% \mathrm{Cl}=0.73-1.00)$. Number of donations made in the first year just failed to reach significance $(\mathrm{OR}=1.27$ $95 \% \mathrm{Cl}=0.99-1.64)$, whilst intention was no longer related to donation.
Table 5a Univariate logistic regression analyses, calculating the odds of donating more than twice (1), compared to donating twice (0).

\begin{tabular}{lcc} 
& \multicolumn{2}{c}{$\begin{array}{c}\text { Adjusted (age \& gender) } \\
\mathrm{OR}^{+}\end{array}$} \\
$\begin{array}{l}\text { Deferral } \\
\mathrm{O}=\text { No } \\
1=\text { Yes }\end{array}$ & 1.46 & \\
\hline Number donations & & $0.89-2.39$ \\
\hline Vasovagal reactions & 1.39 & $1.13-1.71$ \\
\hline Intention & 0.95 & $0.90-1.00$ \\
\hline Anxiety & 1.31 & $0.98-1.76$ \\
\hline Planning failure & 0.88 & $0.76-1.02$ \\
\hline +OR= Odds Ratio, Cl= Confidence Interval & 0.79 & $0.69-0.90$ \\
\hline
\end{tabular}

Table $\mathbf{5 b}$ Multivariate logistic regression analyses, calculating the odds of donating more than twice (1), compared to donating twice (o).

\begin{tabular}{|c|c|c|}
\hline & \multicolumn{2}{|c|}{ Adjusted (age \& gender) } \\
\hline & $\mathrm{OR}^{+}$ & $\mathrm{Cl} 95 \%^{+}$ \\
\hline \multicolumn{3}{|l|}{ Deferral } \\
\hline $\mathrm{O}=\mathrm{No}$ & 1.30 & $0.78-2.17$ \\
\hline $1=$ Yes & & \\
\hline Number donations & 1.27 & $0.99-1.64$ \\
\hline Vasovagal reactions & 0.99 & $0.93-1.05$ \\
\hline Intention & 1.09 & $0.78-1.52$ \\
\hline Anxiety & 0.97 & $0.81-1.16$ \\
\hline Planning failure & 0.85 & $0.73-1.00$ \\
\hline
\end{tabular}

\section{Discussion}

We investigated the importance of past behaviour, intention, vasovagal reactions, deferral and planning failure as predictors of a series of consecutive blood donations in a sample of donors one year after their first donation. The first decision was predicted by past behaviour, intention, vasovagal reactions, and planning failure. The second decision was determined only by intention and planning. The last decision was predicted only be planning failure. The practical implication of these findings is clear 
Early in a donor's career, promoting donation motivation and reducing vasovaga reactions are important to optimising donations but, for those who are retained as donors, planning alone may be critical for retention.

Several change techniques are available to promote action planning and decrease planning failures (Abraham \& Michie, 2008; Abraham, 2012). Ferguson and colleagues (2007) and Masser and colleagues (2008) suggest interventions that make blood donation a fully planned action sequence, including inviting the donor to make an appointment, sending them reminders and contacting them if they fail to keep a donation appointment. Evidence suggests that donors often fail to donate because they find it difficult to fit donation into their busy lives (Van Dongen et al., 2012). Planning interventions, including making if-then plans, have been found to increase people's enactment of their intentions (Gollwitzer \& Sheeran, 2006). Future studie could contribute to reduced withdrawal of blood donors by focusing on the design and evaluation of easy-to-use-in-practice methods of helping motivated donors prioritise donation amid many other important goals. However, since blood donation is essentially a volunteer activity, planning interventions should be designed with caution. Recent research has implicated that too much perceived 'pressure to donate' can have counteractive effects on retention (Wevers, Wigboldus, Van Baaren, \& Veldhuizen, in press). Such interventions may be most effective after donors have established an enduring intention to donate through a series of donations or donation attempts.

The present findings add to a series of studies reporting that anxiety is not a direct predictor of blood donation. Anxiety has been found to predict vasovaga reactions which in turn influence donor retention (Meade, France, \& Peterson, 1996 Ditto \& France, 2006; Viar et al. 2010; Labus, France, \& Taylor, 2000). Anxiety also influences attitude towards donation (Lemmens et al., 2005: Clowes \& Masser, 2012), but anxiety is not a good predictor of experienced donors donation patterns over time. Thus, while it may be important to focus on anxiety reduction in recruiting blood donors this may not be critical to donor retention.

One limitation of this study is the potential self-selection bias. Donors who participated in this study had already completed two previous questionnaires and so may be more motivated than the average donor. However, our response rate of $67 \%$ is not very different to that of other donor surveys in the Netherlands. For example, Van Dongen and colleagues report response rates of $64 \%$ and $65 \%$ for two other large scale donor surveys (Van Dongen, Abraham, Ruiter, \& Veldhuizen, 2012). Moreover, even among this motivated group, a large proportion still failed to continue donating This indicates that the results of the present study should still be generalizable to a larger donor population.

In conclusion, the results show that while motivation, experience of vasovagal reactions and planning failures are all important to early career blood donors, as donors gain more experience only planning failure is a useful predictor of continuing donation. This recommends investment in the design and evaluation of practica approaches to supporting experienced blood donors plan their donations, amid busy lives. 


\section{5}

Does questionnaire distribution promote blood donation? An investigation of question-behavior effects

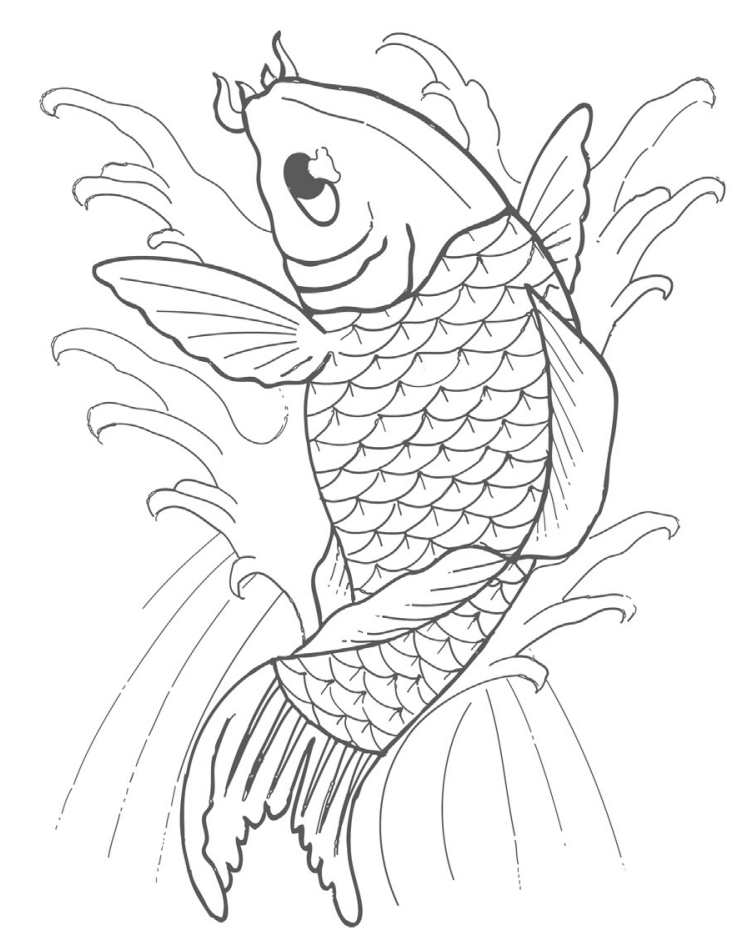

Published as:

Van Dongen A., Abraham, C., Ruiter, R. A.C., \& Veldhuizen, I.J.T. (2013) Does questionnaire distribution promote blood donation? An investigation of question-behavior effects. Annals of Behavioral Medicine, 45, 163-172. 


\section{Abstract}

Objective: To assess the effectiveness survey administration as a population-leve intervention to increase blood donation.

Design: Study 1 was a randomized controlled trail of new donors comparing 3518 who received a questionnaire and 3490 who did not. Study 2 compared matched, random ly-selected samples of active donors; 5789 received a questionnaire while 6000 did not. Study 3 compared data across 5 similar trials.

Main outcome measure: In both empirical studies the dependent measure was the proportion of donors who attended a blood donation centre to give blood within 6 months of survey posting.

Results: No difference in volunteering to give blood was observed between those who did and did not receive a questionnaire among either new or active donors. Similar data patterns were observed across 5 trials.

Conclusion: Despite earlier optimistic findings, there is little evidence to suggest that survey administration per se will be effective in increasing blood supplies.

\section{Introduction}

Researchers routinely ask people what they think about particular behaviors in orde to characterize respondents or predict their future behavior. Such measurement is often assumed to be neutral but may shape respondents' cognitions and behavior. Answering questions may alter one's evaluation of an envisaged action thereby changing attitudes. Recording beliefs and intentions may also modify the salience of pre-existing attitudes, norms or goals and so shift respondents' priorities. Such "question-behavior effects" (QBEs) (Sprott et al., 2006) have been reported in laboratory and field studies. Thus the question arises as to whether QBEs can be used to induce population-level, behavior change.

Sherman (1980) observed that respondents systematically over-predicted the likelihood of engaging in socially-desirable behaviors and under-predicted the likelihood of performing socially-undesirable behaviors, and, importantly, that these self-predictions shaped future behavior. For example, respondents asked about volunteering for charity were more likely to do so than those who were not questioned. Sherman concluded, that, "asking people what they would do in a certain situation assures that they will act that way, even if they would have acted differently without the asking" (p. 215).

Various process explanations of such OBEs have been considered. Studies of cognitive dissonance (Festinger, 1957) demonstrate that writing evaluations, even in private, can shift attitudes towards the evaluated action [e.g. Harmon-Jones, Brehm, Greenberg, Simon, \& Nelson, 1996). Similarly, becoming aware of discrepancies between what we have done and what we should do can prompt action [e.g. Stone, Aronson, Crain, Winslow, \& Fried, 1994). Thus answering questions about our behavior and intentions may create dissonance which questionnaire respondents are motivated to resolve by acting in accordance with their answers. Responding to questionnaires may also activate pre-existing cognitions. For example, the theory of planned behavior has been found to provide a good framework for predicting who is more or less likely to engage in health behaviors, including blood donation (Ajzen, 1991, 2001; Lemmens et al, 2005, 2009; Ferguson et al., 2007). By making behavior-relevant cognitions, such as attitudes, norms and intentions more accessible, answering questions can initiate more-or-less consciously-monitored behavioral regulation processes (Fazio, 1990, 2001, Fitzsimons \& Williams, 2000). Each of these mechanisms may also operate more strongly in the context of socially and/or morally endorsed action (cf. Sprott et al., 2006).

Various health-relevant OBEs have been reported. For example, distributing a questionnaire about cervical screening which assessed cognitions specified by the theory of planned behavior has been found to increase subsequent screening attendance. This study found that those who did not return the questionnaire did not differ from controls in attendance rates but that those who returned completed 
questionnaires attended significantly more often than controls and non-responders (Sandberg \& Conner, 2009). By contrast, a more recent study found that measuring cognitions had no effect on signing up for a tailored health plan. Although in this case combination of the questionnaire with a motivational intervention (a heart-age measure) did increase sign up Ayres et al., 2012). Further research is needed to clarify both what impact QBEs have on health behavior and what potential QBEs have as behavior change interventions, when compared to other intervention strategies.

A variety of reviews of OBEs are available [see e.g. Anderson, Hansen, \& Tripathi, 2010; Conner, Godin, Norman, \& Sheeran, 2011; Dholakia, 2010). In an extensive review ranging over 30 years, Dholakia (2010) focused on the commercial implications of OBEs and distinguished between "self-prophecy effects" in which self-predictions of socially-desirable behaviors promote action (as in volunteering for charity) and "mere measurement effects" in which measuring consumers' satisfaction and purchasing intentions generate sales (e.g. Dholakia \& Morwitz, 2002; Morwitz, Johnson, \& Schmittlein, 1993). Dholakia concluded that, (i) the particular questions researchers ask, (ii) to which respondents, (iii) about what type of behavior, (iv) in what context e.g., laboratory experiment versus field survey, (v) how long before the opportunity for action, and (vi) how researchers measure subsequent behavioral outcomes al influence the strength of observed QBEs.

Our interest is in the potential of survey administration to shape population-leve health-related behavior patterns over time. If OBEs can generate large-scale group change outside laboratories, they could provide a potentially cost effective approach to prompting population-level behavior change.

Blood donation provides a good test of QBEs because (1) blood donation is generally positively evaluated, (2) most people are able to give blood so that motivation rather than competence is central to prompting increased blood donation, (3) blood donation can be measured objectively, and (4) early tests of QBEs have generated promising results.

\section{Can survey administration increase blood donations?}

Blood banks must both encourage donors to make repeat donations and recruit new donors. In the Netherlands, for example, approximately 600,000 whole blood donations are required annually. These are provided by less than 400,000 donors and $10 \%$ of blood donors withdraw each year (Sanquin, 2007). Other countries, including the US, face similar challenges. Aging populations combined with decreasing numbers of blood donors mean that blood banks are struggling to meet demand (Ali, Auvinen, \& Rautonen, 2010; Greinacher et al., 2007; Simon, 2003; Sullivan, Cotton, Read, \& Wallace, 2007).

Canadian research suggests that survey distribution is an effective approach to encouraging already-active donors to increase their donations. Godin and colleagues
(2008) found that receiving a questionnaire measuring donation-relevant cognitions, including intentions to donate, increased blood donation, amongst donors who had already donated, at 6 and 12 months follow up compared to matched controls who did not receive questionnaires. The $\mathrm{QBE}$ observed by Godin and colleagues (2008) was not just a statistically significant difference between groups, but a substantive change that would have important implications for the operation of blood banks. The researchers concluded that, "our findings imply that distributing the questionnaire to blood donors registered with the blood agency would produce 30,000 additional blood donations... that could be translated into 90,000 more life-saving blood transfusions" (p. 183) and rightly emphasized that "interventions to promote health behavior change have not yet developed to the point where we can afford to ignore effects of this magnitude" (p.183)

\section{The Present Studies}

To discover whether these promising findings could be replicated in other contexts, two large-scale, randomized trials were conducted in the Netherlands; one with new blood donors, who had not previously donated and one with experienced, active donors. In both cases we hypothesized that those sent a survey focusing on blood donation would be more likely to donate than those in the no-questionnaire control group. In both cases we measured the effects over six months following survey distribution and used an objective measure of behavior change; the number of people in each group who attended a blood donation centre volunteering a blood donation. No incentives were used. Following analyses of these two empirical studies, we examined data patterns across 5 trials; two reported here and 3 similar, previously reported trials. This comparative, secondary research facilitated examination of the consistency of findings across trials in relation to the effectiveness of QBEs in promoting blood donation. The consistency of findings observed facilitated consideration of the most parsimonious explanation of how questionnaire completion may be related to blood donation.

\section{Methods}

Study 1: New Donors, population, method, randomization and data collection

In the Netherlands, donors must register and attend a medical eligibility check before they are invited to donate blood. Using the Dutch national donor database, we randomly assigned all new, eligible donors to receive or not receive a blood donation survey in the period July 2008 - December 2008. Prior to randomization, those found to have donated previously and those living in areas where their nearest donation centre was open less than once a month were excluded. Questionnaires were sent 
to arrive 10 days before recipients' first appointment at the blood bank. 3,518 new donors received a questionnaire and 3,490 new donors were assigned to the noquestionnaire control group. Figure 1 illustrates the flow of new donors through the trial.

The questionnaire measured a variety of cognitions found to predict blood donation in previous studies (Ferguson et al., 2007; Armitage \& Conner, 2001; Giles et al., 2004; Masser, et al., 2009). Questions were based on published measures (e.g Conner \& Sparks, 2005) and, where possible, were previously-tested Dutch translation (e.g. Lemmens et al., 2005, 2009). Measures included intentions (3 items, Cronbach's Alpha $[a]=.85)$, affective attitudes, that is, how donation will make the respondent feel, ( 3 items, $a=.72$ ), cognitive attitudes, that is what respondents think about blood donation ( 3 items, $a=78$ ), subjective, descriptive and moral norms ( 2 items, $r=.54$, 2 additive items and 3 items, $a=.65$, respectively), self-efficacy ( 4 items, $a=.69$ ), and role identity ( 5 items, $a=65$ ). Items assessing demographic factors, conscientiousness ( 9 items, $a=78$ ) and expectations regarding the donation procedure (20 items) were also included. Most items were measured using a 7-point Likert scale, ranging from (1) completely agree to (7) completely disagree. In total, the questionnaire included 62 items, $40 \%$ of which were cognition questions.

In addition to the questionnaire, those in the experimental arm received an introductory letter explaining the aim of the study and emphasizing that the questionnaire should be completed and returned before their medical eligibility check. This timeframe did not permit reminders but two thirds of recipients completed and returned questionnaires $(2,252$ of 3,$518 ; 64 \%)$

Six months after sending questionnaires we checked the blood donation database to discover whether each of the 7,008 new donors in the trial (3,518 who were sent the questionnaire versus 3,490 who had not) had attended to give blood. We chose this objective measure of behavior (assessed at blood banks) because it is the proximal behavior most likely to be influenced by receiving a questionnaire. The frequency of subsequent donations (e.g., second donations) is likely to be affected by previous donation experiences (e.g. France et al., 2004) and so is less clearly attributable to OBEs. Consequently, we operationalized our research question as: Does receipt of a questionnaire prompt attendance at a blood donation appointment in the 6 months following survey administration.

\section{Study 2: Active donors, population, method, randomization and} data collection

A recent large-scale study, entitled "Donor InSight" (Atsma et al., 2011), employed a survey to investigate epidemiological and psychological correlates of blood donation. This study drew a random sample of current, active, whole-blood from the Dutch national donor database. Questionnaires were sent each month between April 2007
Figure 1 Flow of new donors through the trial

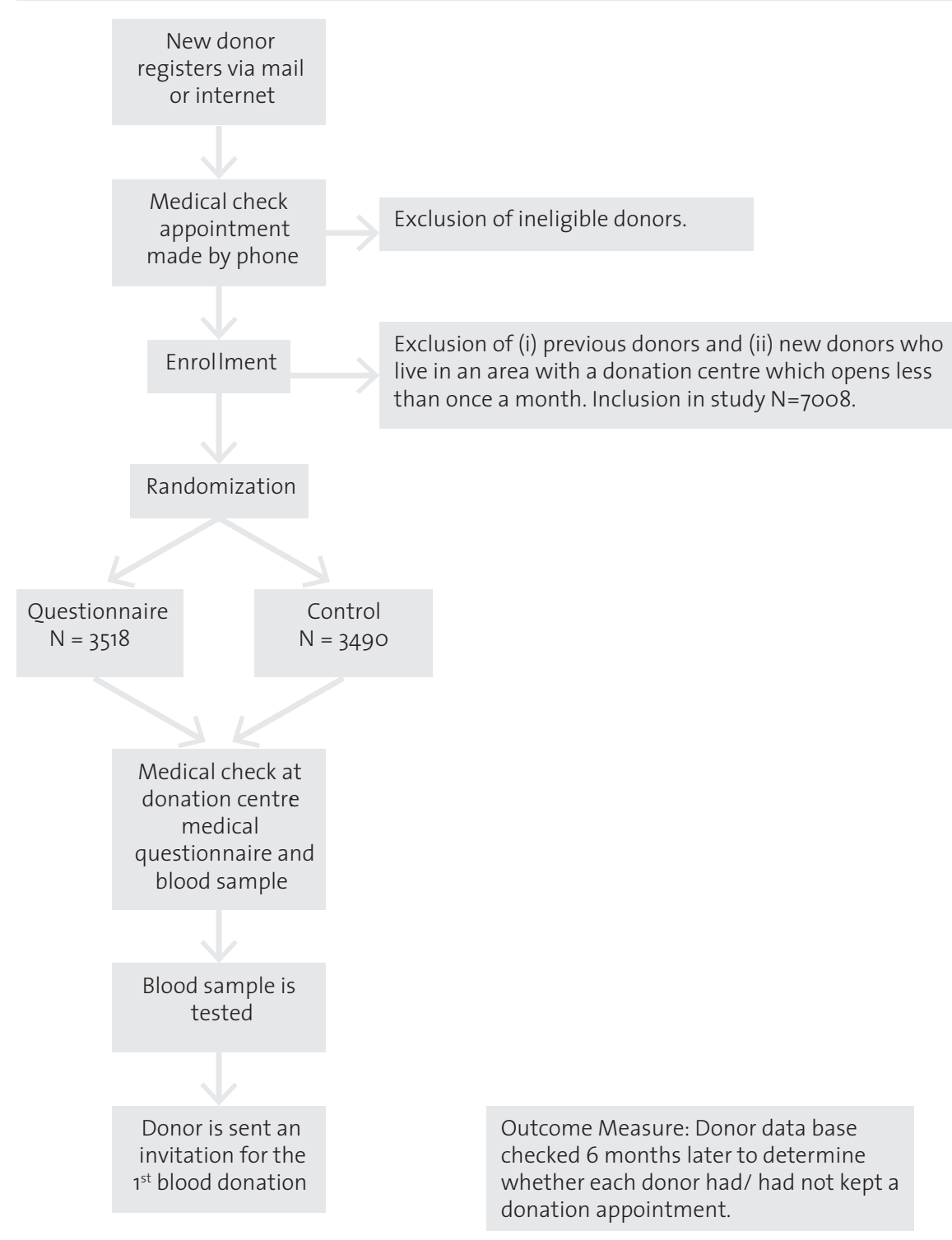

and May 2009 to a total sample of 50,000 active donors. The present study drew a random sample of 6,000 active donors who received this questionnaire between January 2008 and September 2008. From these, 211 new blood donors were excluded leaving a sample of 5,789 active donors 
These 5,789 donors received an introductory letter and a postal questionnaire. If they had not returned the questionnaire within three weeks, they received a reminder. From 5,789 distributed questionnaires, 3,761 were completed and returned (a response rate of $65 \%$ ). Figure $2 a$ illustrates the selection of the active donor questionnaire sample.

Figure $\mathbf{2 a}$ Selection of active donor questionnaire sample

$\begin{aligned} & \text { Questionnaires sent between April } \\ & 2007 \text { and May } 2009 \\ & \text { (N=50,000) }\end{aligned}$
Random selection of 6000 out of
50,000 donors.
Final questionnaire group
$\mathrm{N}=5789$
$(\mathrm{~N}=211)$

As in our study of new donors (described above), the questionnaire used her measured cognitions found to predict blood donation in previous studies. These included measures of intention ( 2 items, $r=.69$ ), affective attitude ( 3 items, $a=.86$ ), cognitive attitude ( 3 items, $a=.58$ ) subjective, descriptive and moral norms ( 2 items, $r$ $=.48,1$ item and 3 items, $a=.73$ ), self-efficacy ( 3 items, $a=.62$ ), habit ( 3 items, $a=.68$ ) and role identity ( 3 items, $a=70$ ). In addition, questions assessed demographic factors, lifestyle, nutrition, physical activity, medical history and reproductive factors. In total, the questionnaire included 144 items, $16 \%$ of which were cognition items.

A matched control group was constructed by drawing 6,000 active donors from the national donor database in January 2008 (the month in which Donor InSight began recruiting), excluding donors who had been sent the questionnaire (see Figure 2b). In this way, we created two randomly-selected directly-comparable samples from the Dutch donor population: one receiving a letter and survey and the other not.
Figure $\mathbf{2 b}$ Selection of active donor control group

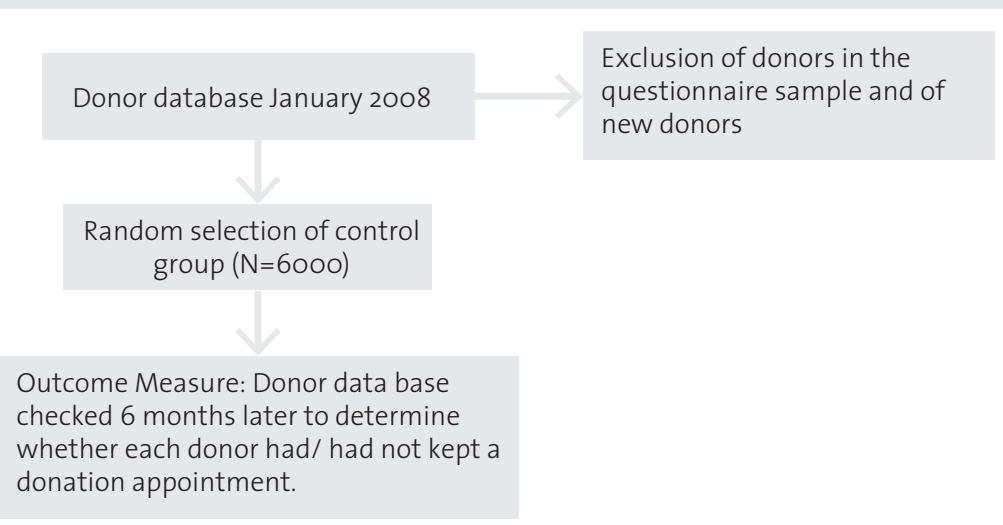

As in the previous study, the outcome measure was whether or not each of the donors ( 5.789 who had received the questionnaire versus 6,000 who had not) did or did not attend a donation appointment in the 6 month follow-up period.

\section{Study 3: A Comparison of 5 Trials}

In study 3 we examined survey response patterns and donation behavior across five trials including the two reported here. Additional data from three Canadian trials were provided by Gaston Godin. We compared blood donation patterns across 3 groups; (i) survey recipients who returned a completed questionnaire, (ii) survey recipients who did not return a questionnaire, and (iii) no-questionnaire controls. We also examined questionnaire return rates and questionnaire length across the 5 trials.

\section{Results}

\section{Study 1: New Donors}

We conducted an intention-to-treat analysis using logistic regression to calculate the odds of attending a donation centre among (i) donors who were randomized to receive a questionnaire versus (ii) donors randomized to the no-questionnaire contro group. We controlled for sex because, in the Netherlands, men are allowed to make more blood donations each year than women (five versus three, respectively). We also controlled for age because previous studies have shown that age is related to number of donations (Veldhuizen et al., 2009).

We found that 2154 of 3518 new donors sent a questionnaire $(61 \%)$ and 2088 of 3490 in the no-questionnaire control group $(60 \%)$ visited a donation centre to 
volunteer a blood donation during the six month follow-up. The groups did not differ significantly in the likelihood of volunteering to donate blood $(\mathrm{OR}=1.06,95 \% \mathrm{Cl}=0.96$ $-1.16)$

\section{Study 2: Active Donors}

Identical analyses (to that used in study 1) were undertaken for study 2 . We found that 3612 of 5789 active donors sent a questionnaire $(62 \%)$ and 3646 of 6000 in the noquestionnaire control group (61\%) visited a blood donation center to give blood during the six-month follow up. The groups did not differ significantly in the likelihood of volunteering to donate $(\mathrm{OR}=1.06,95 \% \mathrm{Cl}=0.99-1.15)$. Thus neither of the two surveys studied here increased blood donations.

\section{Responders vs. non-responders}

Table 1 shows that, in both studies, there was no difference between the no-questionnaire control participants and questionnaire recipients (including responders and non-

Table 1 Demographic characteristics and response rates (studies 1 and 2)

\begin{tabular}{|c|c|c|c|c|c|}
\hline & Total & $\begin{array}{c}\text { Control } \\
\text { Group } \\
\text { (no } \\
\text { questionnaire) }\end{array}$ & $\begin{array}{l}\text { Questionnaire } \\
\text { Recipients }\end{array}$ & & \\
\hline & & & & $\begin{array}{c}\text { Non- } \\
\text { Responders }\end{array}$ & Responders \\
\hline \multicolumn{6}{|c|}{ Study 1 New Donors } \\
\hline$N(\%)$ & $7008(100)$ & $3490(49.8)$ & $3518(50.2)$ & $1266(18.1)$ & $2252(32.1)$ \\
\hline $\begin{array}{l}\text { Age (years), } \\
\text { mean } \pm S D\end{array}$ & $33.4 \pm 12.1$ & $33.1 \pm 12.1$ & $33.7 \pm 12.2$ & $32.4 \pm 11.8$ & $34.4 \pm 12.3$ \\
\hline \multicolumn{6}{|l|}{$\operatorname{Sex}(\%)$} \\
\hline Male & 33.4 & 33.7 & 33.1 & 37.8 & 30.5 \\
\hline Female & 66.6 & 66.3 & 66.9 & 62.2 & 69.5 \\
\hline \multicolumn{6}{|c|}{ Study 2 Active Donors } \\
\hline$N(\%)$ & 11789 (100) & $6000(50.9)$ & $5789(49.1)$ & $2028(17.2)$ & 3761 (31.9) \\
\hline $\begin{array}{l}\text { Age (years), } \\
\text { mean } \pm S D\end{array}$ & $44.8 \pm 13.0$ & $44.6 \pm 12.9$ & $45.0 \pm 13.0$ & $44.8 \pm 13.0$ & $45.1 \pm 13.0$ \\
\hline \multicolumn{6}{|l|}{$\operatorname{Sex}(\%)$} \\
\hline Male & 48.9 & 48.5 & 49.4 & 55.7 & 45.9 \\
\hline Female & 51.1 & 51.5 & 50.6 & 44.3 & 54.1 \\
\hline
\end{tabular}

esponders) in age or gender composition ( $p$ 's >.07). In both studies, however, questionnaire responders differed from non-responders. Among new donors (study 1), older recipients and women were more likely to return their questionnaire ( $p$ 's $<.001$ ) Among active donors (study 2), responders and non-responders did not differ in age $(p=.31)$, but women returned their questionnaires more often than men $(p<.001)$

Table 2 shows the likelihood of donors attending a donation appointment within 6 months for responders (who returned the completed questionnaire) and nonresponders (who did not return a questionnaire). For new donors (Study 1) responders were more likely to donate than no-questionnaire controls ( $O R=1.84,95 \% \mathrm{Cl}=1.64$ 2.01 ), and non-responders were less likely to donate than controls (OR $=0.44,95 \%$ $\mathrm{Cl}=0.39-0.51)$.

Exactly the same pattern was observed for active donors (Table 2 lower panel). Responders were more likely to donate than no-questionnaire controls (OR $=1.47,95 \%$ $\mathrm{Cl}=1.35-1.61)$ and non-responders were less likely to donate within six months than no-questionnaire controls $(\mathrm{OR}=.61,95 \% \mathrm{Cl}=.55-.68)$.

Table 2 Comparison of attendance at a donation appointment within six months among new (Study 1) and active donors (Study 2) using logistic regression.

\begin{tabular}{|cccc}
\hline Study 1 New donors comparisons & OR & p-value & 95\% Confidence Interval \\
\hline Questionnaire - Control (3518/3490) & 1.06 & .257 & $0.96-1.16$ \\
\hline Responders - Control (2252/3490) & 1.84 & .001 & $1.64-2.06$ \\
\hline Non-responders - Control (1266/3490) & 0.44 & .001 & $0.39-0.51$ \\
\hline Study 2 Active donors comparisons & & & \\
\hline Questionnaire - Control (5789/6000) & 1.06 & .110 & $0.99-1.15$ \\
\hline Responders - Control (3761/6000) & 1.47 & .001 & $1.35-1.61$ \\
\hline Non-responders - Control & 0.61 & .001 & $0.55-0.68$ \\
$(2028 / 6000)$ & & & \\
& & &
\end{tabular}

\section{Study 3: A comparison of 5 trials}

Table 3 presents data on donation behavior following survey administration in randomized trials; two reported here and three reported by Godin and colleagues $(2008,2010)$. These trials differ in many respects. Three were conducted in Canada and two in the Netherlands. Two sampled active donors, two sampled donors who had made just one previous donation (Godin et al., 2010) and one (reported here) sampled new donors who had registered to donate but had not yet donated. 
Table 3 Proportion donating blood within 6 months, among non-responders, no-questionnaire controls, and responders, across five studies and study response rates.

\begin{tabular}{|c|c|c|c|c|c|c|}
\hline Study & $\begin{array}{l}\text { Donor } \\
\text { type }\end{array}$ & $\begin{array}{l}\text { Non- } \\
\text { responders }\end{array}$ & Controls & Responders & $\begin{array}{l}\text { Response } \\
\text { rate }\end{array}$ & $\begin{array}{l}\text { Number } \\
\text { of items }\end{array}$ \\
\hline $\begin{array}{l}\text { Van Dongen } \\
\text { et al.. }\end{array}$ & New & $39.9 \%$ & $59.8 \%$ & $73.2 \%$ & $64 \%$ & 62 \\
\hline $\begin{array}{l}\text { Van Dongen } \\
\text { et al.. }\end{array}$ & Active & $49.5 \%$ & $60.8 \%$ & $69.3 \%$ & $65 \%$ & 144 \\
\hline $\begin{array}{l}\text { Godin } \\
\text { et al. 2008* }\end{array}$ & Active & $28.7 \%$ & $49.2 \%$ & $59.1 \%$ & $82 \%$ & 77 \\
\hline $\begin{array}{l}\text { Godin } \\
\text { et al. } 2010\left(I^{+}\right)^{*}\end{array}$ & $\begin{array}{l}\text { Once } \\
\text { only }\end{array}$ & $23.6 \%$ & $30.5 \%$ & $51.8 \%$ & $40 \%$ & 3 \\
\hline $\begin{array}{l}\text { Godin } \\
\text { et al } 2010\left(I^{+} A R^{++}\right)^{*}\end{array}$ & $\begin{array}{l}\text { Once } \\
\text { only }\end{array}$ & $24.9 \%$ & $30.5 \%$ & $48.1 \%$ & $42 \%$ & 6 \\
\hline
\end{tabular}

Questionnaire length and content also differed, although all questionnaires assessed blood donation cognitions including intentions to donate. For example, row 4 of table 3 presents findings for Canadian donors who had donated only once and received (and did/ did not return) or did not receive a questionnaire measuring just intentions to donate. Row 5 presents data from the same population in a trial testing a questionnaire measuring intentions to donate and anticipated regret (in relation to not donating). A variety of cognition measures were included in the questionnaires tested in the other 3 trials. The final column in table 3 presents the number of items in each of the questionnaires. These vary from 3 items to 147 items. Yet length does not explain differences in effectiveness. The short questionnaires including 3 and 6 items used by Godin and colleagues (2010) were ineffective, as were our own longer questionnaires. The only effective questionnaire, used by Godin and colleagues (2008), included 77 items. This was shorter than one of our questionnaires and comparable in length to the other.

Despite these marked methodological differences, the same data pattern is reproduced in all 5 trials. Those who receive and return questionnaires are more likely to volunteer to give blood than those who are not sent questionnaires. Importantly, however, those who are sent questionnaires and do not return them are less likely to donate than no-questionnaire controls. These between-group differences are significant in each trial.
Intention to treat analyses showed that 4 of the 5 trials (reported in Table 3 ) failed to increase blood donation over no-questionnaire controls. Only the trial reported by Godin and colleagues (2008) found that administering a survey increased donations.

\section{Discussion}

Two large, randomized trials investigated whether receipt of a survey questionnaire would increase blood donation among (i) new and (ii) experienced donors in the Netherlands during 6 months following questionnaire posting. The trial of new donors is, to ou knowledge, the first test of question-behavior-effects among new blood donors. No difference in donation volunteering was observed between those who received and did not receive a questionnaire in either trial. Our data consolidate a pattern of findings observed across comparable trials. Godin and colleagues (2010) sent donors who had made only one previous donation questionnaires measuring either (a) intentions to donate or $(b)$ intentions and anticipated regret which might be experienced if recipients did not donate. Neither of these Canadian surveys increased donations at 6 or 12 months. Thus it appears that QBEs are not capable of increasing population-level blood donation.

How can we best understand the discrepancy between the promising results of Godin and colleagues (2008) and that of the other 4 trials considered here? In all 5 trials, questionnaire responders volunteer donations significantly more frequently than no-questionnaire controls who, in turn, volunteer donations significantly more frequently than questionnaire non-responders. Ouestionnaire return rates differed substantially across trials. The Godin and colleagues (2010) trials generated 40-42\% returns, we observed $64-65 \%$ response rates. By contrast, Godin and colleagues (2008) report a questionnaire return rate of $82 \%$. Thus one interpretation of these data is that Godin and colleagues (2008) found a question- behavior effect because they observed an unusually high questionnaire return rate which has not been replicated subsequently. Blood donation surveys may be more likely to increase donations when larger proportions of those receiving a questionnaire complete and return it.

Could interventionists boost QBE effects by maximizing the proportion of questionnaire recipients who return their questionnaires? A systematic review of 292 randomized controlled trials designed to increase questionnaire response rates found use of several strategies to be effective (Edwards, Roberts, Clarke, DiGuispeppi, Prapat, Wentz, et al., 2002). However, evidence appears to be stronger for reminder letters, telephone contact and shorter questionnaires than incentives (Baruch \& Holton, 2008; Nakash, Hutton, Jorstad-Stein, Gates, \& Lamb, 2006). Consideration of this literature emphasizes that if OBEs have any behavior change effect at populationlevel, this is is likely to depend on a variety of factors which influence questionnaire return rates, independently of questionnaire content. 
Willingness to return a questionnaire may reflect more positive, pre-existing attitudes and intentions towards the topic under investigation. For example, Rogelberg, Luong, Sederburg, and Cristol (2000) found that employees who reported that they would not complete a survey about the organization they worked for also had higher intentions to quit their job, a lower organizational commitment, and less work satisfaction. Thus questionnaire return rates may merely reflect differences in underlying motivation to act. However, consideration of reported motivation among those who returned questionnaires does not explain effectiveness or ineffectiveness of questionnaire administration in the trials considered here. No differences in underlying motivation were evident between active donors who responded to the effective Godin and colleagues (2008) questionnaire and those who responded to the ineffective Dutch questionnaire. Active Canadian donors had mean (positive) intentions scores to donate of 4.05 (on a five point response scale, with a standard deviation [SD] of 0.07) while active Dutch donors had mean intention scores to donate of $4.48(S D=0.07)$. On attitude measures, the mean (positive) attitude towards donation for Canadian donors was $4.06(S D=0.59)$ and for Dutch donors 4.16 $(\mathrm{SD}=0.49)$. Thus experienced Canadian and Dutch donors who returned questionnaires had very positive attitudes and intentions towards donation and were no more motivated to donate in the Godin and colleagues (2008) trial than in our own. In both cases these groups made more donations then no-donation controls.

The effect of a questionnaire on subsequent action may depend on an interaction between pre-existing motivation and the impact of the questionnaire on the recipient. The data reported in Table 3 could be explained by attitude polarization effects (Morwitz \& Fitzsimons, 2004). Those with more positive pre-existing cognitions may be prompted to take action after receiving a questionnaire. Conversely, those with less positive pre-existing cognitions may become even less likely to act after receiving a questionnaire. This explanation assumes that those who do not return questionnaires read them and are influenced (negatively) by them, so that the effect of receiving the questionnaire renders non returners less likely to act than no-questionaire controls. Thus, in a worst case scenario, QBEs could have negative effects by both encouraging non return and discouraging action. The data considered here does not rule out this explanation. However, this may not be the most plausible explanation both because of the assumption of questionnaire engagement among non returners and because, among blood donors, motivation is generally high. All participants in the 5 trials considered here (including those who did not return their questionnaires) had already acted on their blood donation motivation; even our new donors had registered as a donor

An alternative interpretation of these data is that willingness to return a questionnaire and to act in accordance with its topic of investigation may be affected by personal characteristics which are not necessarily measured by questionnaire items. Instead of explaining how asking questions in questionnaires may affect future behavior, that is on QBE processes, we might ask what individual characteristic predispose people to either (i) complete and return questionnaires and act in accordance with their expressed views or (ii) fail to respond. Three groups of non-respondents have been identified in the literature; (1) those "unable" to respond, for example, due to illness, (2) those who are "careless", for example, because they misplace the questionnaire and (3) those who are "non-compliant", who actively decide not to complete the questionnaire (Groves, 2006; Groves \& Peytcheva, 2008). Carelessness and non-compliance may be associated with a variety of factors including personality characteristics, such as low conscientiousness or completing goals which render donation less important. These characteristics are likely to have implications, not only for questionnaire completion, but for subsequent behavior (Conner \& Abraham, 2001; Ferguson, 2004). A donor who is "careless" about questionnaire completion may also be "careless" when receiving an invitation to donate blood. Similarly, for example, a less developed donor role-identity Charng, Piliavin, \& Callero, 1988) could also result in greater likelihood of "careless" or "non-compliant" responses both to questionnaire completion and invitations to donate. Thus the effectiveness of population-level QBEs may be partly determined by unmeasured response bias.

In a comprehensive review of QBEs, Dholakia (2010) warned that, while many researchers have not considered the confounding effects of respondent self-selection, "there is a serious [self-selection] concern regarding much of QBE research... [and] all field studies (p.57). Unmeasured participant characteristics have also been highlighted by researchers investigating OBEs on blood donation. Bahrami and colleagues (2011) concluded that enrollment in a survey across 6 blood banks increased overall donations, although not among frequent donors (Bahrami, Guiltinan, Schlumpf, Scott, Banks, D'Andrea, et al., 2011) This report did not present data that could be included in our Table 3 but the authors noted that "we cannot rule out an enrollment bias whereby more committed donors were more likely to enroll in the study" (p. 1210). Thus one parsimonious explanation of the 5 -trial results considered here is that those who do not return questionnaires differ from those that do, not because of underlying donation motivation or because of differential effects of the questionnaire (such as attitude activation), but because questionnaire recipients differ a priori in ways which shape their response both to invitations to complete surveys and to donate blood.

Even though intention to treat analysis is the norm in QBE studies, future studies should consider instrumental variables methodology. This approach corrects for confounding by self-selection (i.e. compliance or non-compliance) in randomised trails, and could therefore be a more suitable analysis to shed light on the role of non-response bias in OBE trails (Greenland, 2000).

Certain conclusions can be drawn. First, questionnaire distribution including blood donation cognition measures is likely to result in higher than control levels of 
blood donation among those who complete and return questionnaires. Nonetheless, it is very unlikely that surveys measuring blood donation cognitions could increase blood donation in the Netherlands either among new or active donors. Moreover, it may be that effective population-level QBEs on blood donation, and perhaps more generally, depend upon high, difficult-to-achieve rates of questionnaire return.

The failure to engineer reliable population-level QBEs on blood donation suggests that blood banks should consider potentially more effective behavior change strategies. We suggest distinguishing between (i) questionnaires designed solely to measure behavior-relevant cognitions (which can test effectiveness of QBEs) and (ii) those which are designed as delivery vehicles for known behavior change techniques based on hypothesized, or established, change mechanisms (Abraham \& Michie, 2008).

The findings of Godin and colleagues (2010) illustrate this distinction. As well as the two QBE trials discussed here, Godin and colleagues (2010) distributed two further questionnaires including implementation intention formation prompts. Implementation intention prompts encourage readers to form if-then plans. This technique influences future behavior by conscious association of cues with already-learnt response (Gollwitzer, 1999; Gollwitzer \& Sheeran, 2006; Sheeran, Webb, \& Gollwitzer, 2005). Experimental research attests to the underlying change mechanisms [e.g. Aarts, Dijksterhuis \& Midden, 1999; Papies, Aarts, \& de Vries, 2009). Moreover, this technique has been found to be effective in isolation and in combination with general action planning among motivated recipients using a wide variety of delivery modes, including questionnaire distribution, and across behaviors. [e.g. Gollwitzer \& Sheeran, 2006 Papies, Aarts, \& de Vries, 2009; Martin, Sheeran, Slade, Wright, \& Dibble, 2011; Luszcynska, Sobczyk, \& Abraham, 2007; Sheeran, Aubrey \& Kellett, 2007). It is encouraging that sending motivated donors questionnaires which invite them to make if-then plans specifying how they will give blood is likely to increase blood donation. It is important to emphasize, however, that specific planning interventions are not QBEE. Prompting if-then plans does not require asking questions or questionnaire distribution. Godin and colleagues (2010) demonstrate the effectiveness of a questionnaire used to promote if-then planning and, simultaneously, the ineffectiveness of questionnaires relying on QBES.

Many other behavior change techniques based on explicit change process can be included in questionnaires and other text formats (Abraham, 2012). We conclude, therefore, that applied researchers switch attention from the very blunt instrument of OBEs which may be affected by a variety of uncontrolled factors and focus on direc utilization of specified behavior change techniques in texts including questionnaires. Research is needed on which ethically-acceptable behavior change techniques are most effective in nudging populations to increase beneficial, health-related behaviors (Michie Abraham, Eccles, Francis, Hardeman, Johnston, 2011; Bartholomew, et al., 2011) Text-based interventions could include simple reminders, prompting if-then plans
(Gollwitzer, 1999), attempts to induce cognitive dissonance (Stone et al., 1994), or a range of other behavior change techniques (Abraham, 2012). Precise specification of intervention content in terms of behavior change techniques would also allow greater precision in identification of which text (including questions) was most effective in combination with which delivery formats for which recipients. 
6

Discussion

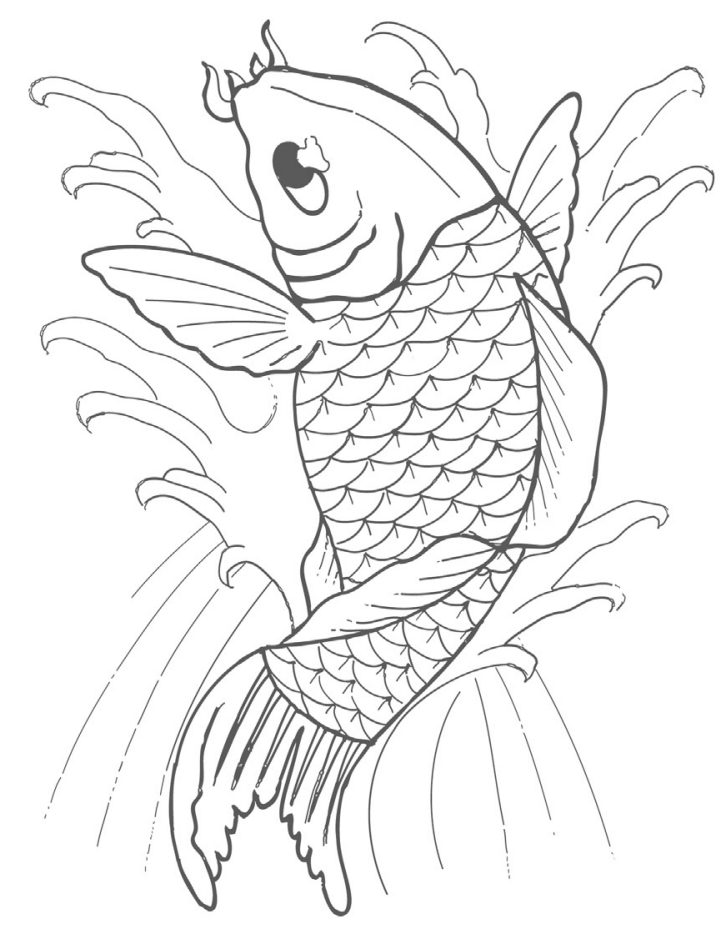




\section{Discussion}

In the Netherlands, as in other European countries, an aging population is reducing the pool of potential blood donors. As a result, the eligible blood donor base is expected to decline since the maximum age to donate blood maintained by the national blood collection establishment Sanquin, is 70 years old. At the same time worldwide, the amount of people needing blood or blood products will increase due to a higher consumption of red blood cell (RBC) units for, for example, cardiac surgery (Greinacher et al., 2007; Ali, Auvinen \& Rautonen, 2010; Seifried et al, 2010; Greinacher et al., 2010). These trends create a challenge for blood donation researchers. Previous work has identified effective donor recruitment strategies (e.g., Lemmens et al., 2008, Lemmens et al., 2010), but further research is needed on donor retention. Donor withdrawal is highest among newly recruited blood donors (Sanquin, eProgesa, unpublished data) so retaining new blood donors is crucial to stabilise blood supplies.

This thesis presents four studies focusing on the retention of new blood donors. The programme of research described here aimed to discover which factors influence retention of new blood donors in order to provide guidance to donation services. We followed donors through their first year of blood donation by sending them questionnaires at three different time points in the first year of their donor career. These data were combined with behavioural data from the donor database. This general discussion will summarise the main outcomes of the four reported studies, consider their strenghts and weaknessess, discuss practical implications for blood donation services, and outline future research opportunities.

\section{Retention of new blood donors}

The first step in the research programme was to find out why donors lapse at all, and once lapsed, what factors could motivate them to restart donations. This study was reported in chapter 2 . The reasons most donors named for lapsing were a busy life and the time it takes to donate blood, vasovagal donor reactions like dizziness and naussea, not feeling fit for donation, and venipuncture problems. These reasons have also been reported by donors in previous studies (Piliavin, 1990; Ferguson, 1996; Ferguson et al., 2007; Masser et al., 2008; Bednall \& Bove, 2011). In addition, we wanted to find out whether lapsed donors could be re-recruited and if so, which factors determine thei willingness to return. A majority of lapsed donors (70\%) indicated to be willing to restart donating blood. Our model based on the Theory of Planned Behaviour (Ajzen 1991) explained $72 \%-85 \%$ of the variance in intention to restart donation. Previous studies among ever-donors (Godin, Sheeran, Conner, Germain, Blondeau, Gagne, et al., 2005) and regular donors (France, France, \& Himawan, 2007) found percentages of explained variance between $65 \%$ and $73 \%$. Cognitive attitude was the main determinant of intention to return for lapsed donors. Self-efficacy also proved to be an 
important determinant of intention. That is, lapsed donors were most willing to return if they thought donating blood again was a positive, good and useful thing to do, and if they felt they were able to donate blood again.

In chapter 3, we explored the effects of vasovagal reactions, fatigue and needle reactions on retention of first-time blood donors. In addition to the experienced physical effects following first-time donation, we investigated whether feelings of anxiety and distress influenced the decision to make a repeat donation. In line with previous studies (France et al., 2004; France, Rader \& Carlson, 2005; Newman et al., 2006; Veldhuizen et al., 2012), we found that the experience of vasovagal reactions decreased the odds of returning for a second donation. In addition, fatigue decreased the odds of making a second donation in men. Needle reactions did not influence retention in either men or women, indicating that needle reactions might be used as rationalization for quiting, but are rarely an actual cause of stopping. Subjective distress also decreased the odds of a second donation, whilst anxiety did not influence retention.

In chapter 4, we investigated the impact of past behaviour, intention, vasovagal reactions, deferral, anxiety and planning on the first, second and third donation decision after filling in a questionnaire. We found that the odds of a first donation were increased by a higher number of donations made in the first year, and a higher score on intention. Higher scores on vasovagal reactions and planning failure decreased the odds of making a repeat donation. The second donation decision was guided by intention and planning failure, whilst the third decision was only influenced by a lower planning failure. Again, anxiety did not seem to determine behaviour.

In chapter 5, we attempted to replicate promising Canadian findings suggesting that sending blood donors questionnaires measuring donation-relevant cognitions increased donations substantially. This 'question behaviour effect' has been said to increase donations by making pre-existing positive attitudes and intentions more salient and therefore, decrease planning failure. We did not, however, replicate these findings in two large representative samples of new and regular donors. Combining our two trials with those of three Canadian trails (described in Godin et al., 2008 and Godin et al., 2010), we found that only one of 5 availabe trials (Canadian regular donors) found an increase in donations following questionnaire distribution. Based on these results, we conclude that it is not likely that sending out questionnaires alone will increase blood donation.

\section{Re-recruiting lapsed donors}

The studies in this thesis have identified several factors that interventions to retain new blood donors could focus on. The study in chapter 2 shows that strategies which focus on cognitive attitude and self-efficacy should be most effective in re-recruiting lapsed donors. Future intervention studies should focus on emphasizing the benefits of donating blood, and increasing feelings of being able to donate to lapsed or lapsing donors. Persuasive techniques such as modelling, planning coping responses and anticipated regret (France et al., 2010; France, France, Wissel, Kowalsky, Bolinger \& Huckins, 2011) have already shown to be effective in increasing attitudes, confidence and intentions towards blood donation, in non-donors and donors. These materials could be adapted to focus on lapsed donors. Intervention Mapping (Bartholomew et al., 2011), a planning process for the systematic theory- and evidence-based development of interventions (for an example of the application of Intervention Mapping, see Kok, Van Essen, Wicker, Llupia, Mena, Correia \& Ruiter, 2011) can be very useful in developing and tailoring such retention materials.

\section{Adverse events}

New donors are negatively affected by vasovagal reactions. They indicated this retrospectively in the lapsed donor study in chapter 2 , and we also found this to be true in chapter 3 when we looked at the prediction of future donation behaviour. In systematic review of interventions, Godin and colleagues (2012) point out that in over 40 years of research in blood donation, remarkably few studies have focussed on intervention studies towards retention of blood donors. One area of exception is the study of adverse events, where detailed interventions to prevent vasovagal reactions have been developed. These results indicate that, in order to increase retention of firs time donors, interventions should focus on decreasing vasovagal reactions. Several interventions like drinking water and applying muscle tension have been tested and found to be effective (Ditto, France, Lavoie, Roussos, \& Adler, 2003; Ditto, Wilkins, France, Lavoie \& Adler, 2003b; Ditto \& France, 2006b; Ditto, France, Albert \& Byrne, 2007; Ditto, Byrne, \& Holly, 2009; Ditto, France, Albert, Byrne, \& Smyth-Laporte, 2009 Hanson \& France, 2004; France, France, \& Patterson, 2006; France, Ditto, Wissel, France, Dickert, Rader, et al., 2010; Newman, Tommolino, Andreozzi, Joychan, Pocedic \& Heringhausen, 2007; Wieling, France, Dijk, Kamel, Thijs, \& Tomasulo, 2011).

Lapsed donors in chapter 2 retrospectively named needle reactions as another cause of lapsing, but the results of our prospective study in chapter 3 did not show this. We suspect, therefore, that needle reactions are used as a rationalization for stopping. Fatigue after blood donation does seem to have an impact on retention in men. Future research should determine the cause of fatigue - is it physiological or psychological, or a combination of both? - and which interventions could be used to counter (the impact of) fatigue in the day(s) after blood donation.

Our findings further showed that the level of subjective distress related to an adverse event influences subsequent donations. Therefore, blood banks could make stress reduction techniques available for donors. For example, Hanson and France (2009) found that, compared with standard donation controls, donors receiving social support during the blood donation reported fewer pre-faint reactions and greater 
likelihood of donating again within the next year. Social support does not necessarily have to be provided by a person known to the donor, as this experiment used research assistants providing encouragement, and distraction in the form of small talk. Another study found that phlebotomists' social skills reduce donor reactions (Stewart, France, Rader, \& Stewart, 2006). In situations other than blood donation, social support has proven to have a stress reducing effect (Fontana, Diegnan, Villeneuve, \& Lepore, 1999 Kamarck, Manuck, \& Jennings, 1990; Lepore, Allen, \& Evans, 1993). Further investigation of social support is warranted. These interventions may be most effective when targeted on those donors that experience high subjective distress (Webb, Miles, \& Sheeran, 2012). Future research should study the characteristics of first time donors who experience high levels of subjective distress at the donation. In addition, the relation between subjective distress and the different adverse events could be studied in more depth, in new donors as well as in regular donors.

\section{The role of anxiety in blood donation}

Findings from the two studies in chapter 3 and 4 suggest that anxiety does not have a direct influence on retention behaviour. Previous studies have found that anxiety does influence attitude towards donation (Lemmens et al., 2005), and the occurrence of vasovagal reactions (Clowes \& Masser, 2012). Attitude and vasovagal reactions, in turn, predict donation behaviour. Ferguson and colleagues (2007) write that ".. emotional responding (anticipated anxieties, vasovagal reactions) ... emerge as key to improving donor recruitment and retention." (p. 2005). However, anxiety does not influence retention in our studies. In addition, we disagree that vasovagal reactions per se are emotional responses. We do argue that coping with vasovagal reactions (subjective distress) influences retention. So what is the influence of emotions on donation intentions and behaviour? Research shows that affective attitudes did not predict donation intentions or behaviour (Conner, Godin, Sheeran \& Germain, 2013). In this study, anticipated positive emotions were the only affective predictor of donation behaviour. This seems in line with studies by Ferguson who found that feelings of "warm glow" (e.g. donating blood because it makes one feel good) are a strong motivator for blood donation; stronger than feelings of reciprocity or altruism (Ferguson, Atsma, De Kort \& Veldhuizen, 2012; Ferguson, Taylor, Keatley, Flynn \& Lawrence, 2012). The role of affect in blood donation remains a matter of interest, and it seems that (anticipated) positive affect has a stronger influence on donation behaviour than negative affect or anxiety.

\section{Planning and time-management}

Lapsed donors in chapter 2 mentionned quiting because of a lack of time. When investigating this in chapter 4 , we found that planning failure acts as a long term determinant of donation behaviour by not only affecting the first consecutive donation decision, but also the second and third decisions. Future studies could contribute to reduced withdrawal of blood donors, by focusing on the design and evaluation of methods of helping motivated donors prioritise donation amid busy daily lives. The key factor in these interventions should be helping people to act on their intentions. Several behaviour change techniques (Abraham \& Michie, 2008; Abraham, 2012; De Bruin, Sheeran, Kok, Hiemstra, Prins, Hospers, et al., 2012) are available to promote action planning and decrease planning failures. Planning interventions, including making if-then plans, have been found to increase people's enactment of their intentions (Gollwitzer, 1999; Gollwitzer \& Sheeran, 2006; Godin et al., 2010). Studies on commitment and consistency could also yield positive results (e.g. Cialdini, 2009). Since a personality trait like conscientiousness could be associated with planning failure (Conner \& Abraham, 2001; Ferguson, 2004), future interventions might be tailored to donors with low conscientiousness.

Ferguson and colleagues (2007) and Masser and colleagues (2008) suggest interventions that make blood donation a fully planned action sequence, including inviting the donor to make an appointment, sending them reminders and contacting them if they fail to keep a donation appointment. In a systematic review of the literature on interventions promoting blood donation, Godin and colleagues (2012) found a small-to-medium effect size of reminders and phone calls on blood donation retention (Godin et al, 2012). Future studies should further determine which interventions are effective in helping donors to plan their donations. Existing literature on action planning and coping planning can help set up experiments to unravel which technique would work best for blood donors (e.g. Sniehotta, 2009)

However, since blood donation is essentially a volunteer activity, planning interventions should be designed with caution. Previous research has implicated that too much perceived 'pressure to donate' can have counteractive effects on retention (Wevers et al., in press). Such interventions may be most effective after donors have established an enduring intention to donate through a series of donations or donation attempts. In addition, removing perceived pressure to donate by adding text like "We understand that it is not always easy to make time for donating blood. That's why we really appreciate it if you make the effort to donate." has shown to increase show rate to invitations in a preliminary study (Boeschen Hospers, Van Geresteijn, Peperkamp, \& Stijnen, 2013)

\section{The question-behaviour effect}

The study reported in chapter 5 suggests that, despite encouraging Canadian results, it is not likely that distribution of cognition questionnaires (relying on question-behaviour effects) is likely to increase donation. Further research is needed, however, to consider whether questionnaires designed specifically to deliver donation-prompting behaviour change techniques (such as if-then planning) could be used as an effective alternative to donation promoting leaflets as a way of prompting donation continuation. 
On the topic of question behaviour effects (QBE's), much remains unclear. First of all, we need definitions of what a 'pure' OBE is, that is the use of questions without intervention content as opposed to the use of questionnaires to deliver known evidence-based change techniques (BCT's). We propose the term QBE should only be used for questionnaires measuring cognitions, that do not incorporate other change techniques such as prompting if-then plans (or implementation intentions) or anticipated regret. Once reserachers have established a definition of OBE, we can start unravelling whether donors are indeed influenced by cognition questions (measures of attitude or intention), or whether we are in fact registering a non-response bias. Methodology is an important issue here. So far, studies have used multiple or logistic regression analyses to analyse the results of OBE studies, however, using instrumental variables analysis (i.e. Greenland, 2000) might prove to be crucial in shedding light on the issue (Ferguson, 2013)

Godin and colleagues continue the investigation by finding an effect on behaviour when intention is asked in the interogative form ("Do I plan to...?"), but not when asked in the declarative form ("I plan to...") (Godin, Belanger-Gravel, Vezina-Im, Amireault \& Bilodeau, 2012). Another study by Ayres and colleagues did not find a OBE when only a questionnaire was used measuring declarative intention, attitudes and anticipated regret, but did find an increased effect when a motivational intervention (i.e. personalised cardiovascular disease risk information) was combined with the cognition questions (Ayres et al, 2013)

\section{Importance of replication}

Our study on the question behaviour effect is in line with current discussions on replicability in the field of social and health psychology (see for example Peters, Abraham \& Crutzen 2012). Perspecitives on Psychological Science just allocated an entire issue to this 'Crisis of Confidence'. After a string of events that put psychological science in a bad light (the Stape fraud case, the Bem publication on extrasensory percention, and the general lack of openness of research methodology), prominent researchers have started to speak out for more openness and more sharing of research materials and data (Pashler \& Wagenmakers, 2012). Replicating the studies done by Godin and collegues $(2008,2010)$ uncovered weaknesses in the definition of $\mathrm{OBE}$, and in the interpretations of the results. Strong inference in science (Platt, 1964, see also De Bruin and Johnston, 2012) starts with formulating alternative explanations that could explain observed results, which is what we did in the discussion section of our paper. The next steps should involve cooperation between all researchers involved, sharing of materials and datasets, clarifying definitons, and devising crucial tests that will exclude one or more alternative explanations. The QBE study proves that replication of results is necessary, not just to test the generalizability of the results, but also because different researchers can think of more alternative hypotheses to explain the data.

\section{Strenghts \& Weaknessess}

Since our studies were all (partly) based on questionniare data, we observe a non-response bias. This is made clear in chapter 5 , where we show that responders as a group donate more often than non-responders as a group. We suspect that this bias does not only occur in our sample, but in many more studies on blood donation behaviour, and perhaps even in studies investigating other types of health behaviour. Unfortunately, most studies on health behaviour only study self-reported behaviou (and thus cannot compare responder behaviour with non-responder behaviour). However, we urge researchers to check for non-response bias in their studies when they do have access to objective behaviour measures.

This non-response bias makes it difficult to generalise our results and conclusions to the entire donor population. Fortunately, the response rates to our questionnaires can be considered high. The response rates were $64 \%$ for questionnaire 1 (used in the OBE study described in chapter 5), 86\% for questionniare 2 (used in the adverse events study described in chapter 3 ) and $76 \%$ for questionnaire 3 (used in the planning study described in chapter 4), which does make our results generalizable to a large part of our donor population.

In the lapsed donor study (chapter 2), we observe a lower response rate of $41 \%$. This may mean that quite a high proportion of lapsed donors may not respond to re-recruitment campaigns. On the other hand, intentions to restart were positive among those who returned the questionnaire suggesting that this group are amenable to re-recruitment. Even if only $30 \%-40 \%$ of actively lapsed donors could be re-recruited this would be a worthwhile return on campaign investment for blood banks.

A limitation of the study on adverse events (chapter 3 ) was that $30 \%$ of responders did not fill in the subjective distress item. After some explorative analyses, we concluded that these missings are probably missing not at random. We ran two sensitivity analyses. First, we ran the logistic regression analysis on the complete cases only. The analyses showed the same pattern of results. Also, we ran the logistic regression analysis after replacing all missings with 1, signifying minimal distress. Again, the results showed the same pattern.

Another issue concerning the studies described in this thesis is that the Dutch donor system differs from several other countries since Sanquin sends out invitation for donations. These invitations serve as written reminders for blood donation, which are considered a retention strategy in itself. However, even among this motivated group who are being sent regular reminders, a large proportion still failed to continue donating. Repeated measurements within a large number of subjects that include actual donation behaviour do provide very strong evidence for actual change in cognitions and prediction of behaviour.

Even though our studies found valuable results for donor retention, these findings are only a starting point for further research. Factors like subjective distress and 
planning failure can not be linked yet to behaviour change theories, and still need to be explored in depth in order to be used in interventions.

\section{Conclusion}

Despite these limitations our findings have strong implications for blood donation practice and for future research agendas. Our studies focused on the crucial first year during which blood collection agencies worldwide are confronted with much drop-out. We have found that re-recruiting lapsed donors could be worth-while. Also,

first-time donors need to be strongly monitored for vasovagal reactions, fatigue, and levels of stress related to adverse events. Helping donors to plan their donation and stick to this plan could have long term effects to increase donor retention. In addition, our study on QBE found that this is probably not an effective intervention to motivate continued donorship. 
Reference List

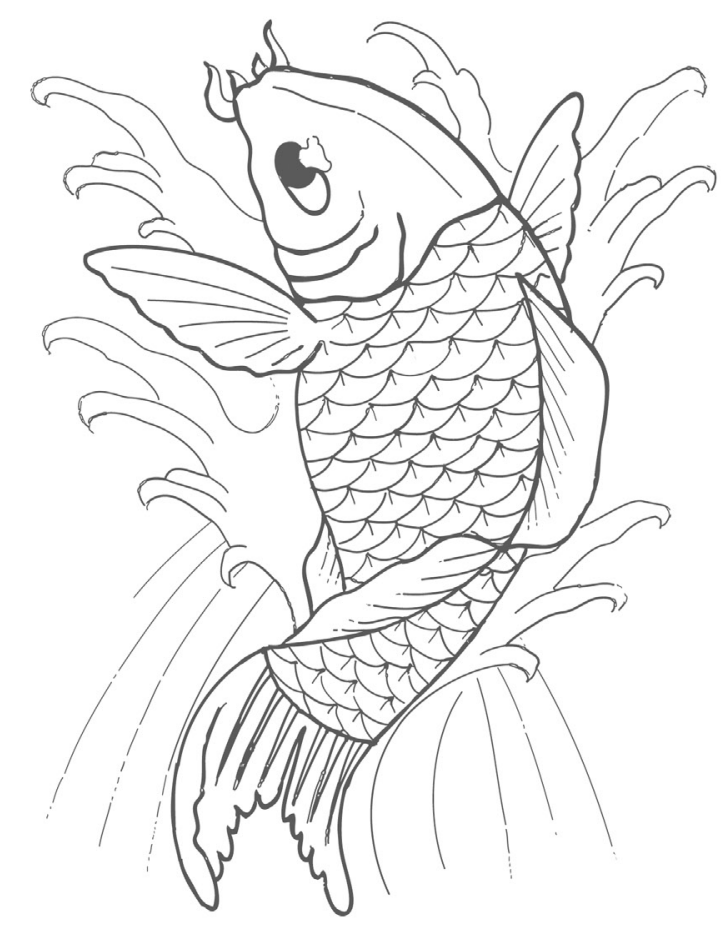




\section{Reference List}

Aarts, H., Dijksterhuis. A., \& Midden, C. (1999). To plan or not to plan? Goal achievement or interrupting the performance of mundane behaviors. European Journal of Social Psychology, 29, 971-979.

Abraham, C. \& Michie, S. (2008). A taxonomy of behavior change techniques used in interventions. Health Psychology, 27, 379-387.

Abraham, C. (2012). Mapping change mechanisms and behaviour change techniques: A systematic approach to promoting behaviour change through text. In C. Abraham, \& M. Kools (Eds.) Writing Health Communication: An Evidence-Based Guide (pp.83-89). London: SAGE Publications Ltd.

Ajzen, I., \& Fishbein, M. (1980). A theory of reasoned action: theoretical implications. Understanding Attitudes and Predicting Social Behavior. Prentice-Hall: Englewood Cliffs, 78-92

Ajzen, I. (1991). The Theory of Planned Behavior. Organizational Behavior and Human Decision Processes, 50 $179-211$.

Airen. I. (2001). Nature and Operation of Attitudes. Annual Review of Psychology, 52, 27-58.

Ali, A., Auvinen, M. K., \& Rautonen, J. (2010). The aging population poses a global challenge for blood services. Transfusion, 50, 584-588.

Anderson, E. T., Hansen, K., \& Tripathi, M. (2010). Measuring the mere measurement effect in non-experimental field settings. Working paper: Northwestern University.

Angst, J., Gamma, A., Clarke, D., Ajdacic-Gross, V., Rossler, W., \& Regier, D. (2010). Subjective distress predicts treatment seeking for depression, bipolar, anxiety, panic, neurasthenia and insomnia severity spectra. Acta Psychiatrica Scandinavica, 122, 488-498,

Archer, G. T., Buring, M. L., Clark, B., Ismay, S. L., Kenrick, K. G., Purusothaman, K.,... Wylie, B. R. (1992). Prevalence of hepatitis C virus antibodies in Sydney blood donors. Medical Journal of Australia, 157(4), 225-227.

Armitage, C. J. \& Conner, M. (2001). Social cognitive determinants of blood donation. Journal of Applied Socid Psychology, 31, 1431-1457,

Atsma, F., Veldhuizen, I. J. T., de Vegt F, Doggen, C. J. M., \& De Kort, W. L. A. M. (2011). Cardiovascular and Demographic characteristics of whole blood and plasma donors: Results from the Donor InSight study. Transfusion, 51, 412-420.

Ayres, K., Conner, M., Prestwich, A., Hurling, R., Cobain, M., Lawton, R., O'Conner, D. B. (2013). Exploring the question-behaviour effect: Randomized controlled trail of motivational and question-behaviou

interventions. British Journal of Health Psychology, 18, 31-44.
Bahrami, S. H., Guiltinan, A. M., Schlumpf, K. S., Scott, E., Banks, L. L., D'Andrea, P., ... Murphy, E. L. (2011) Donation frequency of blood donors participating in a prospective cohort study of iron status. Transfusion, 51(6), 1207-1212.

Bandura, A. (1997). Self-efficacy: the exercise of control. New York: Freeman.

Bartholomew, L. K., Parcel, G. S., Kok, G., Gottlieb, N. H., \& Fernandez, M. E. (2011). Planning Health Promotion Programs: An Intervention Mapping Approach. (3rd Edition) San Francisco: Jossey-Bass.

Baruch, Y., \& Holtom, B. C. (2008). Survey response rate levels and trends in organizational research. Human Relations, 61, 1139-1160.

Bednall, T. C. \& Bove, L. L. (2011). Donating blood: A meta-analytic review of self-reported motivators and deterrents. Transfusion Medicine Review, 25(4), 317-334.

Boeschen Hospers, M., Van Geresteijn, E., Peperkamp, C., \& Stijnen, E. (2013). Regelmatig doneren kun je leren Het verhogen van het opkomstpercentage van volbloeddonors. (Unpublished master's thesis). Radboud University, Nijmegen.

Callero, P. L. \& Pillavin, J. A. (1983). Developing a Commitment to Blood Donation: The impact of One's First Experience. Journal of Applied Social Psychology, 13(1), 1-16.

Callero, P. L., Howard, J. A., \& Piliavin, J. A. (1987). Helping behavior as role behavior: Disclosing social structure and history in the analysis of prosocial action. Social Psychology Quarterly, 50, 247-256.

Callero, P. L. (1992). The meaning of self-in-role: A modified measure of role-identity. Social Forces, 71, 484-501 Charng, H., Piliavin, J. A., \& Callero, P. L. (1988). Role identity and reasoned action in the prediction of repeated behavior. Social Psychology Quarterly, 51, 303-317. 
Clowes, R. \& Masser, B. (2012). Right here, right now: the impact of the blood donation context on anxiety, attitudes, subjective norms, self-efficacy, and intention to donate blood. Transfusion, 52, 1560-1565.

Conner, M. \& Abraham, C. (2001). Conscientiousness and the Theory of Planned Behaviour: Toward a More Complete Model of the

Conner, M. \& Norman, P. (2005). Predicting Health Behaviour. (second edition) Berkshire: Open University Press

Conner, M. \& Sparks, P. (2005). Theory of planned behaviour and health behaviour. In M. Conner \& P. Norman (Eds.), Predicting Health Behaviour (pp. 170-222). Berkshire: Open University Press.

Conner. M. Godin, G. Norman, P. Sheeran, P. (2011) Using the question-behavior effect to promote disease prevention behaviors: Two randomized controlled trials. Health Psychology, 30, 300-309.

Conner, M., Godin, G., Sheeran, P., and Germain, M. (2013). Some feelings are more important: Cognitive attitudes, affective attitudes, anticipated affect, and blood donation. Health Psychology,32(3), 264-272.

Custer, B., Chinn, A., Hirschler, N. V., Busch, M. P., \& Murphy, E. L. (2007). The consequences of temporary deferral on future whole blood donation. Transfusion, 47, 1514-1523.

Custer, B., Schlumpf, K. S., Wright, D., Simon, T. L., Wilkinson, S., \& Ness, P. M. (2011). Donor return after temporary deferral. Transfusion, 51(6), 1188-1196.

De Bruin, M. Sheeran, P., Kok, G., Hiemstra, A., Prins, J. M., Hospers, H. J. \& van Breukelen, G. J. P. (2012). Selfregulatory processes mediate the intention-behavior relation for adherence and exercise behaviors. Health Psychology, 31(6), 695-703.

De Bruin, M., \& Johnston, M. (2012). Methods in health psychology: how do we know what we really know? The European Health Psychologist, 14(4), 107-112.

Dholakia, U. M. \& Morwitz, V. G. (2002). The scope and persistence of mere-measurement effects: evidence from a field study of customer satisfaction measurement. Journal of Consumer Research, 29, 159-167.

Dholakia, U. M. (2010). A critical review of question-behavior effect research. In N. K. Malhotra (Ed.), Review of Marketing Research, Volume 7 (pp. 145-197).

Ditto, B. France, C. R., Lavoie, P., Roussos, M., \& Adler, P. S. (2003a). Reducing reactions to blood donation with applied muscle tension: a randomized controlled trial. Transfusion, 43, 1269-1275.

Ditto, B., Wilkins, J., France, C. R., Lavoie, P., \& Adler, P. S. (2003b). On-site training in applied muscle tension to reduce vasovagal reactions to blood donation. Journal of Behavioral Medicine, $26(7), 53-65$.

Ditto, B. \& France, C. R. (2006a). Vasovagal symptoms mediate the relationship between predonation anxiety and subsequent blood donation in female volunteers. Transfusion, 46, 1006-1010.

Ditto, B. \& France, C. R. (2006b). The effects of applied tension on symptoms in French-speaking blood donors: A randomized trail. Health Psychology, $25(3), 433-437$.

Ditto, B., France, C. R., Albert, M., \& Byrne, N. (2007). Dismantling applied tension: Mechanisms of a treatment to reduce blood donation-related symptoms. Transfusion, $47(12), 2217-2222$.

Ditto, B., Byrne, N., \& Holly, C. (2009a). Physiological correlates of applied tension may contribute to reduced fainting during medical procedures. Annual Behavioural Medicine, 37, 306-314.

Ditto, B., France, C. R., Albert, M., Byrne, N., \& Smyth-Laporte, J. (200gb). Effects of applied muscle tension on the likelyhood of blood donor return. Transfusion, 49, 858-862.

Donders, A. R., van der Heijden, G. J., Stijnen, T., \& Moons, K. G. (2006). Review: a gentle introduction to imputation of missing values. Journal of Clinical Epidemiololgy, 59, 1087-1091.

Edwards, P., Roberts, l., Clarke, M., DiGuiseppi, C., Pratap, S., Wentz, R., Kwan, I. (2002) Increasing respons rates to postal questionnaires: Systematic review. BMJ, $324-1183$.

Fazio, R. H. (1990). Multiple processes by which attitudes guide behaviour: the MODE model as an integrative framework. In: M. P. Zana (Ed). Advances in Experimental Social Psychology (pp. 75-109). San Diego: Academic Press.

Fazio, R. H. (2001). On the automatic activation of associated evaluations: An overview. Cognition \& Emotion $15,115-141$. of the psychological literature on blood donation. British Journal of Health Psychology, 1(4), 287-308.
Ferguson, E. \& Bibby, P. A. (2002). Predicting future blood donor returns: past behavior, intentions, and observer effects. Health Psychology, 21, 513-518.

ferguson, E. (2004). Conscientiousness, emotional stability, perceived control and the frequency, recency, rate and years of blood donor behaviour. British Journal of Health Psychol, 9, 293-314.

Ferguson. Journal of Health Psychology, 10, 359-372.

Ferguson, E., France, C. R., Abraham, C., Ditto, B. \& Sheeran, P. (2007). Improving blood donor recruitment and retention. integrating theoretical advances from social and behavioral science research agendas. Transfusion, 47, $1999-2010$.

Ferguson, E., Farrell, K. \& Lawrence, C. (2008). Blood donation is an act of benevolence rather than altruism. Health Psychology, 27, 327-336.

Ferguson, E., Taylor, M., Keatley, D., Flynn, N. and Lawrence, C. (2012). Blood donors' helping behavior is driven by warm glow:more evidence for the blood donor benevolnce hypothesis Transfusion, 52, 2189 -2200.

Ferguson, E Atsma F, de Kort W. and Veldhuizen L. (2012), Exploring the pattern of blood donor beliefs in (t) altruism, and warm glow. Transfusion, 52,343-355.

Ferguson, E. (2013). Non-Compliance and Instrumental Variables in Behavioural Medicine: a Commentary on van Dongen et al. Annals of Behavioral Medicine, 45, 137-138.

Festinger, L. A. (1957). Theory of Cognitive Dissonance. Standford: University Press.

Fitzsimons, G. J. \& Williams, P. (2000). Asking questions can change choice behavior: does it do so automatically or effortfully? Journal of Experimental Psychology: Applied, 6, 195-206.

Follea, G., Veldhuizen, I., Redpath, G., Jarnig, M. and Kral, M. (2010). Donor retention. In: W. De Kort, L Veldhuizen (Eds.), Donor Management Manual (pp. 103-122). DOMAINE.

Fontana, A. M., Diegnan, T., Villeneuve, A., Lepore, S.J. (1999). Nonevaluative social support reduces cardiovascular reactivity in young women during acutely stressful performance situations. Journal of Behavioural Medicine, 22(1), $75-91$

France, C. R. France, J. L. Roussos, M. \& Ditto, B. (2004). Mild reactions to blood donation predict a decreased likelihood of donor return. Transfusion Apheresis Science, 30, 17-22.

France, C. R., Rader, A., \& Carlson, B. (2005). Donors who react may not come back: analysis of repeat donation as a function of phlebotomist ratings of vasovagal reactions. Transfusion Apheresis Science, 33, 99-106.

France, C. R., France, J. L., \& Patterson, S. M. (2006). Blood pressure and cerebral oxygenation responses to skeletal muscle tension: a comparison of two physical maneuvers to prevent vasovagal reactions Clinical Physiology and Functional Imaging, 26, 21-25.

France, J. L., France, C. R., \& Himawan, L. K. (2007). A path analysis of intention to redonate among experience blood donors: an extension of the theory of planned behavior. Transfusion, 47, 1006-1013.

France, C. R., Ditto, B., Wissel, M. E., France, J. L., Dickert, T., Rader, A. Sinclair, K., McGlone, S., Trost, Z. an Matson, E. (2010a). Predonation hydration and applied muscle tension combine to reduce presyncopa reactions to blood donation. Transfusion, $50(6), 1257-1264$.

France, C. R., France, J. L., Kowalsky, J. M. \& Cornett, T. L. (2010b). Education in donation coping strategies encourages individuals to give blood: further evaluation of a donor recruitment brochure. Transfusion 50, 85-91.

France, C. R., France, J. L., Wissel, M. E., Kowalsky, J. M., Bolinger, E. M. and Huckins, J. L. (2011). Enhancing blood donation intentions using multimedia donor education materials. Transfusion, 51, 1796-1801.

Giles, M., McClenahan, C., Cairns, E., \& Mallet, J. (2004). An application of the Theory of Planned Behaviour to blood donation: the importance of self-efficacy. Health Education Research, 19, 380-391.

Glynn, S. A., Kleinman, S. H., Schreiber, G. B., Busch, M. P., Wright, D. J., Smith, J. W., Nass, C. C., \& Williams, A. E. (2000). Trends in incidence and prevalence of major transfusion-transmissible viral infections in US blood donors, 1991 to 1996. Retrovirus Epidemiology Donor Study (REDS). Jama, 284, 229-235.

Glynn, S. A., Kleinman, S. H., Schreiber, G. B., Zuck, T., Mc Combs, S., Bethel, J., Garratty, G., Williams, A. E. and Retrovirus Epidemiology Donor Study (2002). Motivations to donate blood: demographic comparisons. Transfusion, 42, 216-225. 
Godin, G., Sheeran, P., Conner, M., Germain, M., Blondeau, D., Gagne, C., Beaulieu, D., \& Naccache, H. (2005). Factors explaining the intention to give among the general population. Vox Sanguinis, 89, $140-149$. Godin, G., Conner, M. Sheeran, P., Belanger-Gravel, A. \& Germain, M. (2007). Determinants of repeated blood donation among new and experienced blood donors. Transfusion, 47, 1607-1615.

Godin, G., Sheeran, P., Conner, M., \& Germain, M. (2008). Asking questions changes behavior: mere measurement effects on frequency of blood donation. Health Psychology, 27, 179-184.

Godin, G., Sheeran, P., Conner, M., Delage, G., Germain, M., Belanger-Gravel, A., \& Naccache, H. (2010). Which survey questions change behavior? Randomized controlled trial of mere measurement interventions. Health Psychology, 29, 636-644

Godin, G. Vezina-Im, L. Belanger-Gravel, A. \& Amireault, S. (2012). Efficcay of interventions promoting blood donation: A systematic review. Transfusion Medicine Reviews, 26(3), 224-237.

Godin, G. Bélanger-Gravel, A. Vézina-Im. L. Amireault, S. and Bilodeau, A Ouestion-behaviour effect. A randomised controlled trial of asking intention in the interrogative or declarative form. (2012). Psychology \& Health, 27(9), 1086-1099.

Gollwitzer, P.M. (1999). Implementation intentions: Strong effects of simple plans. Americam Psychologist, 54 493-503.

Gollwitzer, P. M. \& Sheeran, P. (2006). Implementation intentions and goal achievement: A meta-analysis of effects and processes. Advances in Experimental social Psycholgy, 38, 249-268.

Greenland, S. (2000). An introduction to instrumental variables for epidemiologists. International Epidemiological Association, 29, 722-729.

Greinacher, A., Fendrich, K., Alpen, U., \& Hoffmann, W. (2007). Impact of demographic changes on the blood supply: Mecklenburg-West Pomerania as a model region for Europe. Transfusion, 47, 395-401.

Greinacher, A., Fendrich, K., \& Hoffmann, W. (2010). Demographic changes: The impact for safe blood supply. Transfusion Medicine Hemotherapy, 37, 141-148.

Greinacher, A., Fendrich, K., Brzenska, R., Kiefel, V. and Hoffmann, W. (2011). Implications of demographics on future blood supply: a population-based cross-sectional study. Transfusion, 51, 702-709.

Grossman, P. Niemann, L., Schmidt, S., Walach, H. (2004). Minfulness-based stress reduction and health benefits: A meta-analysis. Journal of Psychosomatic Research, 57, 35-43.

Groves, R. M. (2006). Nonresponse rates and nonresponse bias in household surveys. Public Opinion Quarterly. $70,646-675$

Groves, R. M. \& Peytcheva, E. (2008). The im Public Opinion Quarterly, 72, 167-189.

Hanson, S. A. \& France, C. R. (2004). Predonation water ingestion attenuates negative reactions to blood donation. Transfusion, 44, 924-928.

Hanson, S. A. \& France, C. R. (2009). Social support attenuates presyncopal reactions to blood donation Transfusion, 49, 843-850.

Harmon-Jones, E., Brehm, J. W., Greenberg, J., Simon, L., Nelson, D. E. (1996). Evidence that the production of aversive consequences is not necessary to create cognitive dissonance. Journal of Personality and Socia Psychology, 70, 5-16.

Kakaiya, R. M., Jacobs, B., Pelletier, M., Morse, E. E., \& Cable, R. G. (1986). Trends in hepatitis B surface antigen (HBsAg) prevalence in volunteer blood donors in Connecticut, 1973-1983. Annals of Clinical and Laboratory Science, $16(5), 380-385$

Kamarck, T. W., Manuck, S. B., Jennings, J. R. (1990). Social support reduces cardiovascular reactivity to psychological challenge: a laboratory model. Psychosomatic Medicine, $52(1), 42-58$.

Kok, G., van Essen, G. A., Wicker, S., Llupia, A., Mena, G., Correia, R. \& Ruiter, R. A. C. (2011). Planning for influenza vaccination in health care workers: An Intervention Mapping approach. Vaccine, 29, 8512-8519.

Koyama, T., McHaffie, J. G., Laurienti, P. J., \& Coghill, R. C. (2005). The subjective experience of pain: where expectations become reality. Procedings of the National Academy of Sciences of the U.S.A., 102, 12950-12955 . Vurvey International Journal of Behavioral Medicine, $7.62-72$.
Lemmens, K. P., Abraham, C., Hoekstra, T., Ruiter, R. A., de Kort, W. L., Brug, J. \& Schaalma, H. P. (2005). Why don't young people volunteer to give blood? An investigation of the correlates of donation intentions among young nondonors. Transfusion, 45, 945-955.

Lemmens, K. P., Abraham, C., Ruiter, R. A., Veldhuizen, I. J., Bos, A. E., \& Schaalma, H. P. (2008). Identifying blood donors willing to help with recruitment. Vox Sanguinis, 95, 211-217.

Lemmens, K. P., Abraham, C., Ruiter, R. A., Veldhuizen, I. J., Dehing, C. J., Bos, A. E. \& Schaalma, H. P. (2009).

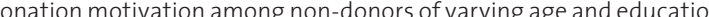
British Journal of Psychology, 100, 71-90.

Lemmens, K. P. H., Ruiter, R. A. C., Abraham, C., Veldhuizen, I. J. T., \& Schaalma, H. P. (2010). Motivating blood donors to recruit new donors: Experimental evaluation of an evidence-based behavior change intervention. Health Psychology, 29, 601-609.

Lemmens, K. P. H. (2009). The systematic recruitment of new blood donors (Doctoral dissertation). Maastricht: Maastricht University.

Lepore, S. J., Allen, K. A., Evans, G. W. (1993). Social support lowers cardiovascular reactivity to an acute stressor. Psychosomatic Medicine, $55(6), 518-524$.

Luszczynska, A., Sobczyk, A. \& Abraham, C. (2007). Planning to lose weight: RCT of an implementation intention prompt to enhance weight reduction among overweight and obese women. Health Psychology, 26, 507-512.

Martin, J., Sheeran, P., Slade, P., Wright, A. \& Dibble, T. (2011). Durable effects of implementation intentions: Reduced rates of confirmed pregnancy at two years. Health Psychology, 2011, 30, 368-373.

Masser, B. M., White, K. M., Hyde, M. K., \& Terry, D. J. (2008). The psychology of blood donation: current research and future directions. Transfusion Medicine Review, 22, 215-233.

Masser, B. M., White, K. M. Hyde, M. K., Terry, D. J. \& Robinson, N. G. (2009). Predicting blood donation intentions and behavior among Australian blood donors: testing an extended theory of planned behavior model. Transfusion, 49, 320-329.

Meade, M. A. France, C. R. \& Peterson, L. M. (1996). Predicting vasovagal reactions in volunteer blood donors. Journal of Psychosomatic Research, 40, 495-501.

Michie, S., Abraham, C. Eccles, M. P. Francis, J. J Hardeman, W., \& Johnston, M. (2011) Methods for strengthening evaluation and implementation: specifying components of behaviour change

Morwitz, V. G., Johnson, E., \& Schmittlein, D. (1993). Does measuring intent change behavior? Journal of Consumer Research, 20, 46-6.

Morwitz, V. G. \& Fitzsimons, G. J. (2004). The Mere-Measurement Effect: Why Does Measuring Intention Change Actual Behavior? Journal of Consumer Psychology, 14, 64-74

Nakash, R. A., Hutton, J. L., Jorstad-Stein, E. C., Gates, S., Lamb, S. E. (2006). Maximising response to postal questionnaires: A systematic review of randomised trials in health research. BMC Medical Research Methodology, 6: 5 .

Newman, B. H., Pichette, S., Pichette, D., \& Dzaka, E. (2003). Adverse effects in blood donors after whole-blood donation: a study of 1000 blood donors interviewed 3 weeks after whole-blood donation. Transfusion 43, 598-603.

Newman, B. H., Newman, D. T., Ahmad, R., \& Roth, A. J. (2006). The effect of whole-blood donor advers events on blood donor return rates. Transfusion, 46, 1374-1379.

Newman, B., Tommolino, E., Andreozzi, C., Joychan, S., Pocedic, J., \& Heringhausen, J. (2007). The effect of 473- $\mathrm{mL}$ (16-oz) water drink on vasovagal donor reaction rates in high-school students. Transfusion, 47 $1524-1533$

Newman, B. H. \& Siegfried, B. A. (2011). The quest to reduce vasovagal reactions in young blood donors. Transfusion, 51, 2061-2063.

guyen, D. D., Devita, D. A., Hirschler, N. V. \& Murphy, E. L. (2008). Blood donor satisfaction and intention of future donation. Transfusion, 48, 742-748

Nilsson Sojka, B. \& Sojka, P. (2003). The blood-donation experience: perceived physical, psychological and social impact of blood donation on the donor. Vox Sanguinis, 84, 120-128. 
Oswalt, R. M. (1977). A review of blood donor motivation and recruitment. Transfusion, 17, 123-135.

Papies, E. K., Aarts, H., de Vries, N. K. (2009). Planning is for doing: Implementation intentions go beyond the mere creation of goal-directed associations. Journal of Experimental Social Psychology, 45, 1148-1151.

Pashler, H. \& Wagenmakers, E. (Eds.). (2012). A crisis of confidence? [Special issue]. Perspectives in Psychological Science, $7(6)$.

Peters, G. J. Y., Abraham, C. S., \& Crutzen, R. (2012). Full disclosure: doing behavioural science necessitates sharing. The European Health Psychologist, 14(4), 77-84.

Petty, R. E. \& Cacioppo, J. T. (1986). The elaboration likelihood model of persuasion. In L.Berkowitz (Ed). Advances in Experimental Social Psychology (pp. 123-205). New York: Academic Press.

Piliavin, J. A. (1990). Why do they give the gift of life? A review of research on blood donors since 1977 Transfusion, 30, 444-459.

Platt, J.R. (1964). Strong Inference: Certain systematic methods of scientific thinking may produce much more rapid progress than others. Science, 146, 347-53.

Rainville, P., Bao, Q. V., \& Chretien, P. (2005). Pain-related emotions modulate experimental pain perception and autonomic responses. Pain, 118, 306-318.

Rogelberg, S. G., Luong, A., Sederburg, M. E., \& Cristol, D. S. (2000). Employee attitude surveys: examining the attitudes of noncompliant employees. Journal of Applied Psychology, 85, 284-293.

Rubin, D. B. (1987). Multiple Imputation for Nonresponse in Surveys. New York: J. Wiley \& Sons.

Sandberg, T. \& Conner, M. (2009). A mere measurement effect for anticipated regret: Impacts on cervical screening attendance. British Journal of Social Psychology, 48, 221-236.

Schlumpf, K. S., Glynn, S. A., Schreiber, G. B., Wright, D. J., Randolph, S. W., Tu, Y., Hermansen, S., Higgins, M. J, Garratty, G., \& Murphy E. L. (2007). Factors influencing donor return. Transfusion, 48, $264-272$.

Schreiber, G. B., Glynn, S. A., Damesyn, M. A., Wright, D. J., Tu, Y., Dodd, R. Y. \& Murphy, E. L. (2003). Lapsed donors: an untapped resource. Transfusion, 43, 17-24.

Schreiber, G. B., Sharma, U. K., Wright, D. J., Glynn, S. A., Ownby, H. E., Tu, Y., Garratty, G., Piliavin, J., Zuck, T., \& Gilcher, R. (2005). First year donation patterns predict long-term commitment for first-time donors. Vox Sanguinis, $88,114-121$

Schreiber, G. B., Schlumpf, K. S., Glynn, S. A., Wright, D. J., Tu, Y., King, M. R., Higgins, M. J., Kessler, D., Gilcher, R, Nass, C. C., \& Guiltinan, A. M. (2006). Convenience, the bane of our existence, and other barriers to donating. Transfusion, 46, 545-553.

Seifried, E., Klueter, H., Weidmann, C., Staudenmaier, T., Schrezenmeier, H., Henschler, R., Greinacher, A. and Mueller, M. M. (2011). How much blood is needed? Vox Sanguinis, 100, 10-21.

Sheeran, P., Webb, T. L., \& Gollwitzer, P. M. (2005). The interplay between goal intentions and implementation intentions. Personality and Social Psychology Bulletin, 31, 87-98.

Sheeran, P., Aubrey, R., \& Kellett, S. (2007). Increasing attendance for psychotherapy: Implementation intentions and the self-regulation of attendance-related negative affect. Journal of Consulting and Clinical Psychology, 75, 853-863.

Sherman, S. J. (1980). On the self-erasing nature of errors of prediction. Journal of Personality and Socia Psychology, 39, 211-221.

Simon, T. L. (2003). Where have all the donors gone? A personal reflection on the crisis in America's volunteer blood program. Transfusion, 43, 273-279.

Sinclair, K. S., Campbell, T. S., Carey, P. M., Langevin, E., Bowser, B., \& France, C. R. (2010). An adapted postdonation motivational interview enhances blood donor retention. Transfusion, 50, 1778-1786.

Sniehotta, F. F. (2009). Towards a theory of intentional behaviour change: Plans, planning, and self-regulation British Journal of Health Psychology, 14, 261-273.

sprott, D. E., Spangenberg, E. R., Block, L. G., Fitzsimons, G. J., Morwitz, V. G., \& Williams, P. (2006). The question-behaviour effect: What we know and where we go from here. Social Influence, 1, 128-137.

stewart, K. R., France, C. R., Rader, A. W. and Stewart, J. C. (2006). Phlebotomist interpersonal skill predicts reduction in reactions among volunteer blood donors. Transfusion, 46, 1394-1401.
Sullivan, M. T., Cotten, R., Read, E. J., \& Wallace, E. L. (2007). Blood collection and transfusion in the United States in 2001. Transfusion, 47, 385-394.

Tomasulo, P.. Kamel, H., Bravo, M. James, R. C., \& Custer, B. (2011). Interventions to reduce the vasovaga reaction rate in young whole blood donors. Transfusion, 51, 1511-1521.

Van Dongen, A., Abraham, C., Ruiter, R., Schaalma, H., De Kort, W., Dijkstra, A., Veldhuizen, I. J. T. (2012). Are lapsed donors willing to resume blood donation, and what determines their motivation to do so? Transfusion, 52, $1296-1302$

Van Dongen A., Abraham, C., Ruiter, R. A., \& Veldhuizen, I. (2012). Does questionnaire distribution promote ion? An investigation of questio 163-172.

Van Dongen A. Abraham, C. Ruiter, R. A.C. and Veldhuizen, I. J. (2013). The influence of adverse reactions, subjective distress, and anxiety on retention of first-time blood donors. Transfusion, 53, 337-343.

Van Dongen A., Ruiter R.A.C., Abraham C., \& Veldhuizen I. (2013). Predicting blood donation maintenance: The importance of planning future donations. Transfusion. doi: 10.1111//trf.12397

Veldhuizen, I. J. T., Doggen, C. J. M., Atsma, F., \& De Kort, W. L. A. M. (2009). Donor profiles: demographic factors and their influence on the donor career. Vox Sanguinis, 97, 129-138.

Veldhuizen, I., Folléa, G., Degiorgio, A., Bart, T., Fontana, S., Tschaggelar, A. \& Levy, G. (2010). Donor Recruitment. In W.de Kort \& I. Veldhuizen (Eds.), Donor Management Manual (1 ed., pp. 84-102). Domaine.

Veldhuizen, I. J. T. \& Wagenmans, E. T. (2010). DOMAINE survey on Donor Management in Europe. In: W. de Kort \& I.J. T. Veldhuizen (Eds.), Donor Management Manual - DOMAINE project.

Veldhuizen, I., Ferguson, E., de, K. W., Donders, R., \& Atsma, F. (2011). Exploring the dynamics of the theory of planned behavior in the context of blood donation: does donation experience make a difference? Transfusion, 51, 2425-2437.

Veldhuizen, I., Atsma, F., van Dongen, A., \& de Kort, W. (2012). Adverse reactions, psychological factors, and their effect on donor retention in men and women. Transfusion, 52(9), 1871-1879.

Veldhuizen, I., Folléa, G. and de Kort, W. (2013). Donor cycle and donor segmentation: new tools for improving blood donor management. Vox Sanguinis. doi: 10.1111/vox.12018

Veldhuizen, I. \& Van Dongen, A. Motivational differences between whole blood and plasma donors already exist before their first donation experience. Transfusion. DOI: 10.1111/trf.12056

Viar, M. A., Etzel, E. N., Ciesielski, B. G., \& Olatunii, B. O. (2010). Disgust, anxiety, and vasovagal syncope sensations: A comparison of injection-fearful and nonfearful blood donors. Journal of Anxiety Disorders, 24(8), $941-945$.

Webb, T. L. \& Sheeran, P. (2006). Does changing behavioral intentions engender behavior change? meta-analysis of the experimental evidence. Psychological Bulletin, 132, 249-268.

Webb, T. L., Miles, E., \& Sheeran, P. (2012). Dealing with feeling: A meta-analysis of the effectiveness of strategies derived from the process model of emotion regulation. Psychological Bulletin, 138(4), 775 808 .

Wevers, A. Wigboldus, D. H. J., Van Baaren, R. \& Veldhuizen, I. J. T. Return behavior of occasional an multi-gallon blood donors: The role of TPB, self-identity and organizational variables. Manuscript accepted for publication

Wieling, W., France, C. R., Van DIJk, N., Kamel, H., Thijs, R. D., \& Tomasulo, P. (2011). Physiologic strategies to prevent fainting responses during or after whole blood donation. Transfusion, 51 (12), 2727 - 2738. 


\section{Summary}

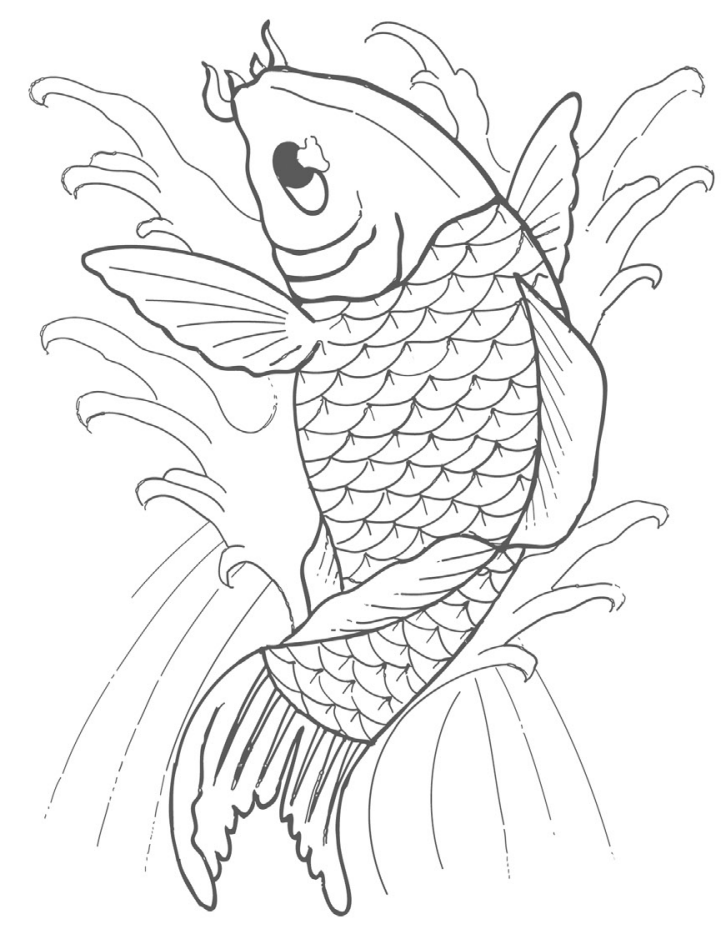




\section{Summary}

Stable national blood supplies are essential to healthcare services but aging populations are likely to reduce donor numbers in many countries. Unfortunately, he Dutch donor pool, like the donor pool in other countries, has been declining for years. This thesis describes the results of a research project focussing on retention of new blood donors.

Chapter 1 provides a general introduction to the four empirical studies. It describes the recruitment problems blood collection establishments are facing, emphasizing the need for a stable donor population. The research that has been done to investigate donor recruitment methods is summarized. In addition, we focus on the importance of retention of new donors. Known motivators and barriers to retention of blood donation are discussed. We emphasize that not many interventions have been tested focussing on the retention of (new) donors. Finally, the empirical studies that are reported in this thesis are introduced.

Chapter 2 describes a study which aimed to find out whether lapsed donors would be willing to return as blood donors. Reasons for donation cessation motivation to re-start donation, and modifiable components of donation motivation were examined. We distinguished between lapsed donors who had passively withdrawn by not responding to donation invitations and donors who had contacted the blood bank to actively withdraw. We found that $13 \%$ of these voluntarily lapsed donors indicated to have quit because of physical reactions, $10 \%$ because of needle reactions, and $14 \%$ because they had trouble planning their donation. The majority of lapsed donors indicated a moderate to high intention to restart donations. Results showed that cognitive attitude was the strongest correlate of intention to donate in the future, with self-efficacy also explaining a useful proportion of the variance. It is concluded that persuasive messages will be most effective when they focus on enhancing cognitive attitudes and self-efficacy.

The study described in chapter 3 focused on the effects of vasovagal reactions, needle reactions and fatigue at the first blood donation on retention. In addition, we explored the effects of self-reported anxiety and subjective distress on retention, after the experience of an adverse reaction. Of donors who experienced an adverse event at their first donation, $9 \%$ did not return for a second donation. For both men and women, vasovagal reactions decrease the likelihood of successful retention Fatigue decreases retention in men and subjective distress decreases retention in women. In addition to decreasing vasovagal reactions, retention interventions could productively target coping with fatigue and reducing subjective distress following adverse reactions.

Chapter 4 describes a study that investigates donors who had donated for the first time in the previous year. We studied whether planning and anxiety, in addition 
to past behaviour, intention, vasovagal reactions, and deferral are associated with donation behaviour in the immediate future. In addition, we looked at factors that determine continuation decisions regarding repeated blood donations. Analyses distinguished between 1) those who registered for donation following questionnaire completion, versus those who did not, 2) those who did or did not register for donation a second time following questionnaire completion, and 3) those who did or did not register for donation a third time following questionnaire completion. Results showed that the first donation decision was influenced by intention, number of donations made in the first year, vasovagal reactions and planning failure. The second donation decision was influenced by intention and planning failure, whilst the third decision was influenced only by planning failure. This indicates that for new donors, retention efforts should focus on the promotion of a positive intention and decreasing vasovagal reactions. However, improving planning and goal completion could be an even better investment since planning seems to determine long term retention.

Finally, the three studies described in chapter 5 tried to establish whether sending a questionnaire to new and regular blood donors in itself changed donation behaviour. This hypothesized effect is called the question-behaviour effect. In the first two studies, the dependent measure was the proportion of donors who attended a blood donation centre to give blood within 6 months of survey posting. Study 3 compared data across five similar trials, our two studies and three Canadian studies. No difference in volunteering to give blood was observed between those who did and did not receive a questionnaire among either new or active donors. We concluded that sending and completing the questionnaire does not change behaviour. Importantly, we found a clear dispositional difference between responders and non-responders in donation behaviour. Donors who are willing to fill in a questionnaire about blood donation donate blood more often following the study invitation than those that did not respond. Despite earlier optimistic findings, we thus found little evidence to suggest that survey administration per se will be effective in increasing blood supplies.

Chapter 6 provides a discussion of the results of all studies. We conclude that early in a donor's career, promoting donation motivation and reducing vasovagal reactions are important target points for retention interventions, as is coping with fatigue and subjective distress associated with any adverse event. There is little evidence to suggest that question behaviour interventions will be an effective behavioural change technique among those who are retained as donors. For this group, planning is critical to retention. Investment in the design and evaluation of practical approaches to support experienced blood donors in planning their donations could yield therefore good results in retaining donors for an even longer time. 


\section{Samenvatting}

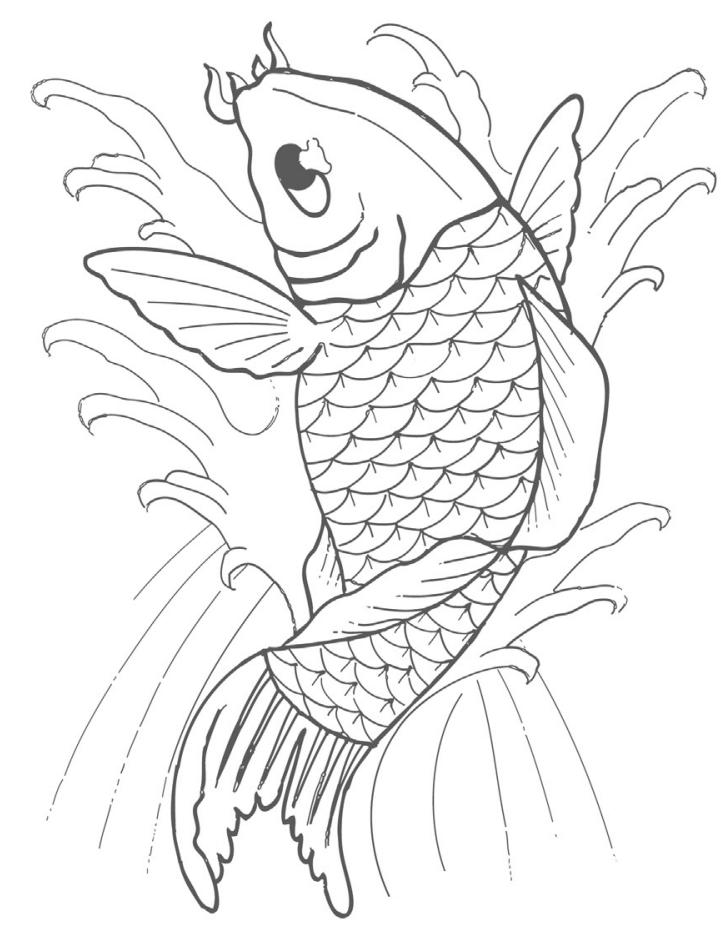




\section{Samenvatting}

Een stabiele bloedvoorraad is essentieel voor de gezondheidszorg. De vergrijzing kan ervoor zorgen dat minder bloed van gezonde bloeddonors beschikbaar wordt, terwij meer mensen donorbloed nodig hebben. Dit proefschrift beschrijft de resultaten van een onderzoeksproject gericht op het behoud van nieuwe bloeddonors.

Hoofdstuk 1 is een algemene inleiding. Aan bod komen de problemen waar bloedvoorzieningen tegenaan lopen. Hieruit blijkt dat een stabiele donorpopulatie noodzakelijk is. We beschrijven eerdere onderzoeken naar donorwerving. Ook kijken we naar het belang van donorbehoud. We beschrijven de motivatoren en barrières die inmiddels bekend zijn, maar we benadrukken dat er nog weinig onderzoek is gedaan, speciaal gericht op nieuwe donors. We geven de hiaten in onze kennis weer en we kijken vooruit naar de inhoud van de studies in dit proefschrift.

Hoofdstuk 2 beschrijft een onderzoek naar de werving van gestopte donors. Stopredenen, motivatie om opnieuw bloed te gaan geven en veranderlijke factoren die een rol spelen bij de motivatie om te doneren zijn onderzocht. We maken een onderscheid tussen donors die uitgeschreven zijn omdat ze niet gereageerd hebben op herhaalde donatieoproepen, en donors die zelf contact hebben opgenomen om hun donorschap op te zeggen. Uit de resultaten bleek dat 13\% van de vrijwillig gestopte donors was gestopt vanwege fysieke reacties, 10\% vanwege naaldreacties en 14\% omdat ze moeite hadden met het inplannen van een donatie. De meerderheid van de gehele groep gestopte donors gaf aan een hoge intentie te hebben om opnieuw bloed te gaan geven. Cognitieve attitude was het sterkst gecorreleerd met de intentie om weer te doneren. Self-efficacy verklaarde ook een proportie van de variantie. We concluderen dat wervingscampagnes het meest effectief zullen zijn als ze focussen op het beïnvloeden van cognitieve attitudes en self-efficacy.

Het onderzoek in hoofdstuk 3 richt zich op de effecten van vasovagale reacties, naaldreacties en vermoeidheid bij de eerste donatie op het behoud van nieuwe donors. Daarbij bestuderen we de effecten van angst voor de donatie, en stress naar aanleiding van de fysieke reactie op behoud. Van de donors die een fysieke reactie kregen bij hun eerste donatie kwam $9 \%$ niet terug voor een tweede donatie. Zowel bij mannen als vrouwen hebben vasovagale reacties een negatief effect op de terugkee voor een donatie. Mannen die vermoeidheid ervaren na de donatie komen minder vaak terug, terwijl bij vrouwen de ervaren stress de kans op een volgende donatie vermindert. Naast strategieën die vasovagale reacties verminderen, zouden interventies zich ook moeten richten op vermoeidheid na een donatie en het omgaan met stress

Hoofdstuk 4 beschrijft een onderzoek naar donors die een jaar eerder hun eerste donatie hadden gedaan. We hebben onderzocht of planning en angst, naast eerder donatiegedrag, intentie, vasovagale reacties en tijdelijk medisch uitstel, allen gemeten 
met een vragenlijst, geassocieerd zijn met donatiegedrag in de nabije toekomst. Daarbij hebben we gekeken naar factoren die drie opeenvolgende beslissingen om bloed te doneren beïnvloedden. De analyses maakten onderscheid tussen 1) donors die wel of niet kwamen doneren na het invullen van de vragenlijst, 2) donors die wel of niet een tweede keer kwamen doneren na het invullen van de vragenlijst, en 3 ) donors die wel of niet een derde keer kwamen doneren na het invullen van de vragenlijst. De resultaten lieten zien dat het besluit om de eerste keer te doneren beïnvloed wordt door intentie, het aantal donaties dat de donor in het eerste jaar had gedaan, vasovagale reacties en planning. Intentie en planning beïnvloeden de beslissing om de tweede keer te gaan doneren. Het besluit om de derde keer bloed te geven, wordt alleen beïnvloed door planning. Dit geeft aan dat strategieën voor het behoud van nieuwe donors zich moeten richten op het creëren van een positieve intentie en het verlagen van vasovagale reacties. Het verbeteren van planningsvaardigheden zou wellicht een betere investering zijn, aangezien planning donorbehoud op de lange termijn beïnvloedt.

Met de studies die we beschrijven in hoofdstuk 5 proberen we vast te stellen of het sturen van een vragenlijst naar nieuwe en actieve bloeddonors donatiegedrag verandert. Dit mogelijke effect wordt het 'vraag-gedrag effect' genoemd. In de eerste twee studies was de afhankelijke variabele het aandeel donors dat een afnamecentrum bezocht om te doneren binnen zes maanden na het ontvangen van een vragenlijst. In studie drie hebben we de resultaten van deze twee studies vergeleken met de data van drie studies die eerder in Canada plaats hadden gevonden. We vonden geen verschil tussen donors die wel of niet een vragenlijst hadden ontvangen. We concluderen dat het sturen en invullen van een vragenlijst geen gedragsverandering veroorzaakt, maar dat er wel een duidelijk verschil in donatiegedrag is tussen mensen die de vragenlijst besluiten in te vullen en zij die dat niet doen. Donors die bereid zijn een vragenlijst in te vullen over bloeddonatie zijn ook bereid om vaker bloed te doneren. Ondanks eerdere optimistische resultaten hebben we weinig bewijs gevonden dat enkel het versturen van vragenlijsten effectief zal zijn in het stimuleren van bloeddonatie.

In hoofdstuk 6 bespreken we de resultaten van alle gerapporteerde studies. We concluderen dat het stimuleren van de motivatie om te doneren en het verlagen van vasovagale reacties vroeg in de donorcarrière belangrijk zijn voor donorbehoud. Leren omgaan met vermoeidheid en de stress die gepaard gaat met fysieke reacties zijn ook van belang. Voor mensen die al minimaal een jaar donor zijn kan alleen planning a bepalend zijn voor behoud. Met het ontwikkelen en evalueren van praktische interventies die ervaren donors helpen met het plannen van hun donaties, zouden goede resultaten bereikt kunnen worden. Er is echter weinig bewijs dat vraag-gedrag interventies een effectieve gedragsveranderingsmethode zijn voor deze groep. 


\section{Dankwoord}

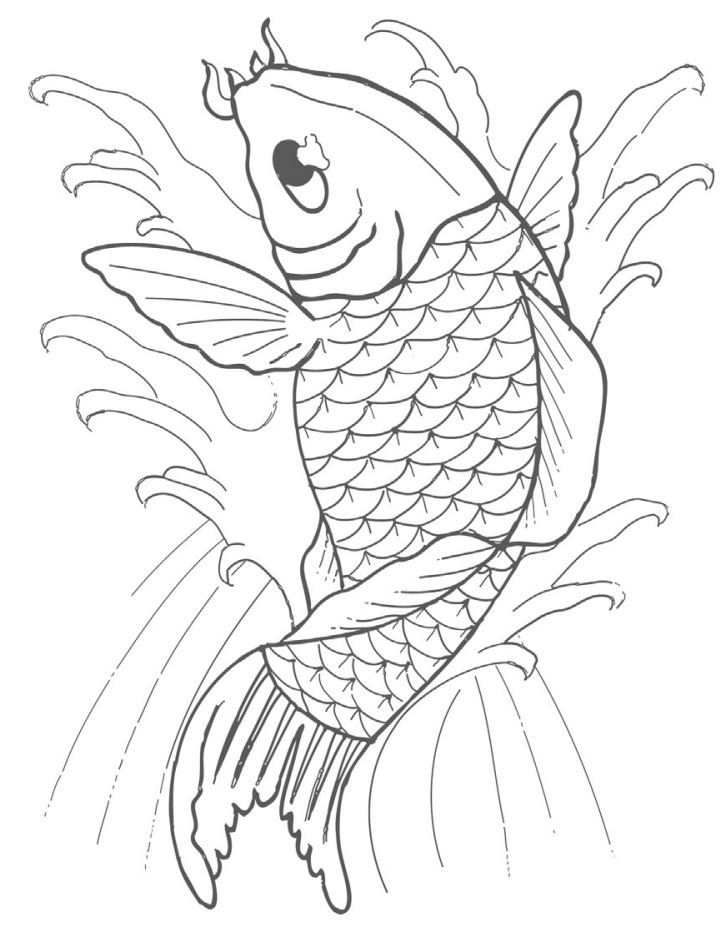




\section{Dankwoord}

Toen ik begon aan dit proefschrift was ik zes jaar uit de psychologie en vier jaar uit de academische wereld. Na een baan als secretaresse, een reis naar Australië, een baan als callcenter medewerker, een reis naar Afrika, twee jaar vrijwilligerswerk, een halve HBO opleiding en heel veel afwijzingen op sollicitatiebrieven had ik nooit gedacht dat mij ooit nog de kans geboden zou worden om te promoveren. Voor dat voorrecht zal ik Wim en Ingrid eeuwig dankbaar blijven.

Ingrid: bedankt voor je begeleiding en je vriendschap. Jouw vertrouwen in mij, je luisterend oor en je inhoudelijke begeleiding hebben mij door dit hele traject heen gesleept.

Herman: gone but definitely not forgotten.

Charles: thank you for taking over my supervision when Herman died. Long distance thesis supervision has been difficult at times, but your guidance has made my thesis that much better.

Rob: bedankt voor het overnemen van mijn begeleiding, voor de samenwerking, je steun, je kritische blik en je snelle reacties.

Karin $\mathrm{H}$ : jij bent de enige aan wie ik mijn onderzoek durf over te laten. Deze thesis is mede door jouw geweldige en onvermoeibare hulp tot stand gekomen.

Dilana: omdat ik een congres al niet overleef zonder jou, zou ik niet durven te promoveren zonder jou als paranimf. Rock on!

Pa: jouw liefde voor boeken, puzzels en kennis hebben mijn nieuwsgierigheid als kind altijd aangewakkerd. Dank voor je antwoorden op al mijn vragen toen ik klein (en al iets groter) was. Ik ben er trots op dat ik de derde generatie Dr. van Dongen Torman word.

Ma: van jou heb ik de interesse in literatuur, kunst, muziek en mensen meegekregen Dank voor al onze gesprekken en je steun. Ik kijk uit naar veel after-work borrels in Amsterdam.

Frank: bedankt voor je prachtige ontwerpen. Zowel die op de omslag van dit boekje als op mijn eigen omslag. 
Mijn vroegere en huidige collega's bij Sanquin: Mireille, Anne W, Elze, Karlijn, Nienke, Maurits, Wim, Katja, Josian, Ellen, Bas, Karen, Femke, Paul, Pieternel, Marian, Carine, Moritz, alle oud-collega's van de DIL, de dames van de donor administratie, de dames van de afname, de afdeling Communicatie en het team van artsen. Dank voor de hulp, de steun en de gezelligheid.

Mijn vroegere collega's van de UM: Saar, Hans, Fraukje, GJ, Sarah, Gerjo, Gerda, Sanne, Birthe, Loes, Karin L, Karlijn, Esther, Dirk, Hermien, Irene, Lisette, Alvin, John, Henna, Alicia, Arjan, Carolin, Joke. Bedankt dat jullie me meteen welkom lieten voelen toen ik als 'extern' aan kwam zetten in het verre Maastricht. Dank voor de gezelligheid bij de croissantjes en de lunch, tijdens uitjes en op de EHPS. Een extra woord van dank aan Mariëlla voor alle hulp als ik het Maastrichtse systeem weer eens niet snapte, en natuurlijk voor de gezellige babbel.

My former colleagues at Sussex University: thanks for making me feel welcome from day one onwards. I will never forget Falmer Friday! A special thanks to Linda for the bed, breakfast \& wine arrangement at hotel Tip-Thun.

Huize 27 en de rest van de Brons voor een luisterend oor, moral support, bier en kampvuurtjes.

Mijn chickies Noor, Nico, Bir en Eri voor alle bbq's, terrasjes, etentjes, festivallen, concerten en andere afleidingen van het promotieproces. World peace! Sandrino voor steun, bier (I have respect for beer) en alle goede en diepgaande gesprekken. Dennis voor onze fijne en vertrouwde gesprekken bij lekker eten.

De mensen die ik hier niet bij naam heb genoemd maar die wel op bepaalde momenten in de afgelopen zes jaar er voor mij waren op wat voor manier dan ook: bedankt. 
